Engineer Research and

Development Center

\title{
Ririe Dam Release Test Assessment
}

Steven F. Daly, Meredith Carr, Stephen Hall, and Jeremy Giovando

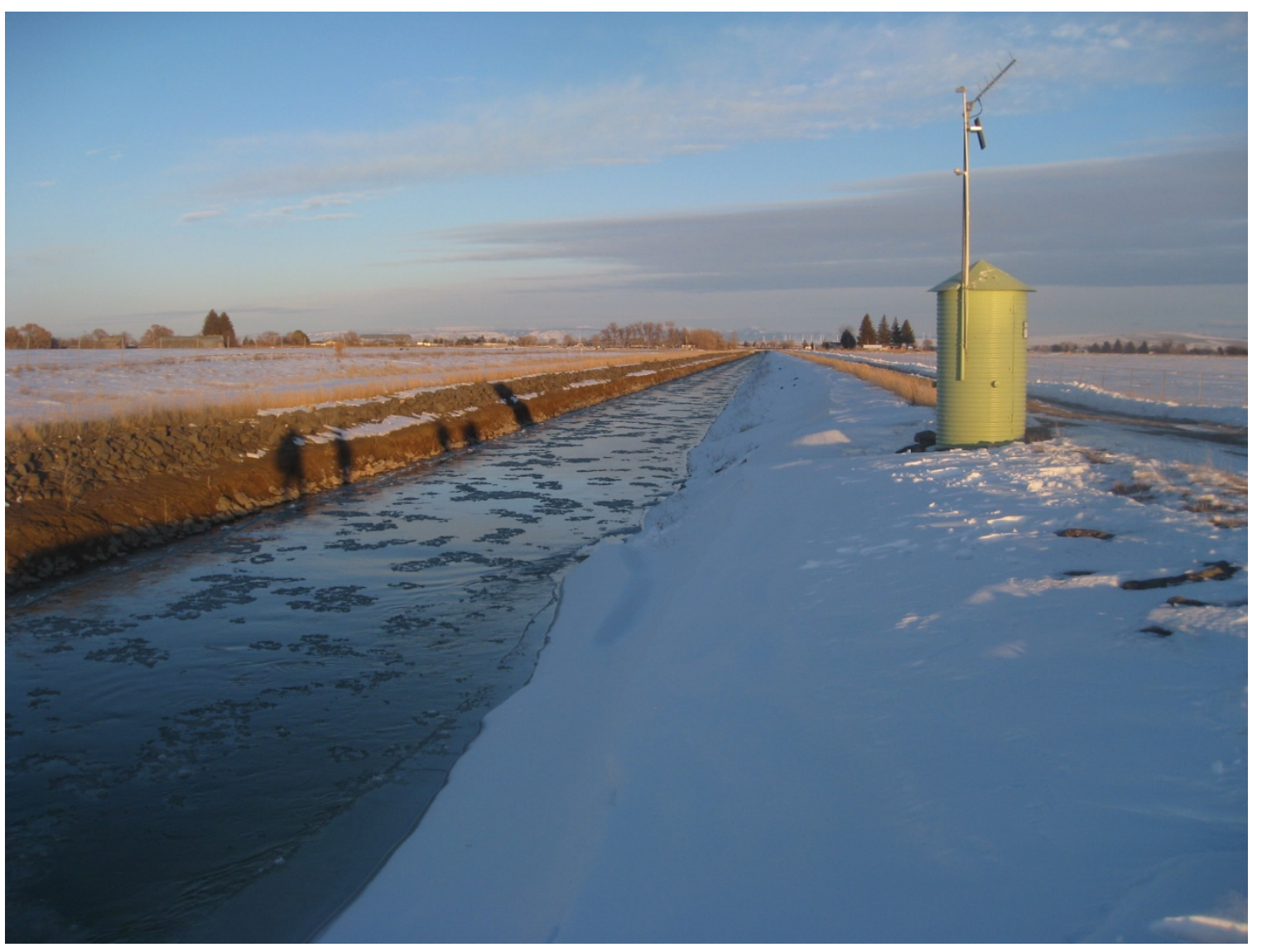


The US Army Engineer Research and Development Center (ERDC) solves the nation's toughest engineering and environmental challenges. ERDC develops innovative solutions in civil and military engineering, geospatial sciences, water resources, and environmental sciences for the Army, the Department of Defense, civilian agencies, and our nation's public good. Find out more at www.erdc.usace.army.mil.

To search for other technical reports published by ERDC, visit the ERDC online library at http://acwc.sdp.sirsi.net/client/default. 


\title{
Ririe Dam Release Test Assessment
}

\author{
Steven F. Daly and Meredith Carr \\ Cold Regions Research and Engineering Laboratory (CRREL) \\ US Army Engineer Research and Development Center \\ 72 Lyme Road \\ Hanover, NH 03755-1290 \\ Stephen Hall and Jeremy Giovando \\ US Army Engineer District, Walla Walla \\ 201 North Third Avenue \\ Walla Walla, WA 99362-1876
}

Final Report

Approved for public release; distribution is unlimited.

\footnotetext{
Prepared for Headquarters, US Army Corps of Engineers

Washington, DC 20314-1000
} 


\section{Abstract}

To potentially increase storage over the winter season, the US Army Corps of Engineers (Corps) Walla Walla District (NWW) is currently evaluating flood control operations at Ririe Reservoir. Because there is little experience with winter releases and a previous winter release resulted in minor flooding, it is important to understand the potential problems associated with releases in these conditions. Therefore, the Corps conducted a Release Test on 10-13 February 2013. Throughout the test, instruments took detailed measurements of the water temperature, stage, and discharge along the Willow Creek channel; and personnel observed the dynamic ice conditions.

The test included an initial release of $150 \mathrm{cfs}$ for $28 \mathrm{hr}$; a rapid increase to $300 \mathrm{cfs}$, which was held for $14.5 \mathrm{hr}$; and another rapid increase to $500 \mathrm{cfs}$, which was held for $24 \mathrm{hr}$. The flow was then shut off. Neither the Initial Release Wave nor subsequent flow significantly removed, dislodged, or eroded snow in the channel; the snow melted only after a thermal melt-out front advanced downstream. No out-of-bank flooding occurred.

As a result of the information gathered from this Release Test and from one in 2011, this report presents a series of recommendations for future wintertime releases.

DISCLAIMER: The contents of this report are not to be used for advertising, publication, or promotional purposes. Citation of trade names does not constitute an official endorsement or approval of the use of such commercial products. All product names and trademarks cited are the property of their respective owners. The findings of this report are not to be construed as an official Department of the Army position unless so designated by other authorized documents. 


\section{Contents}

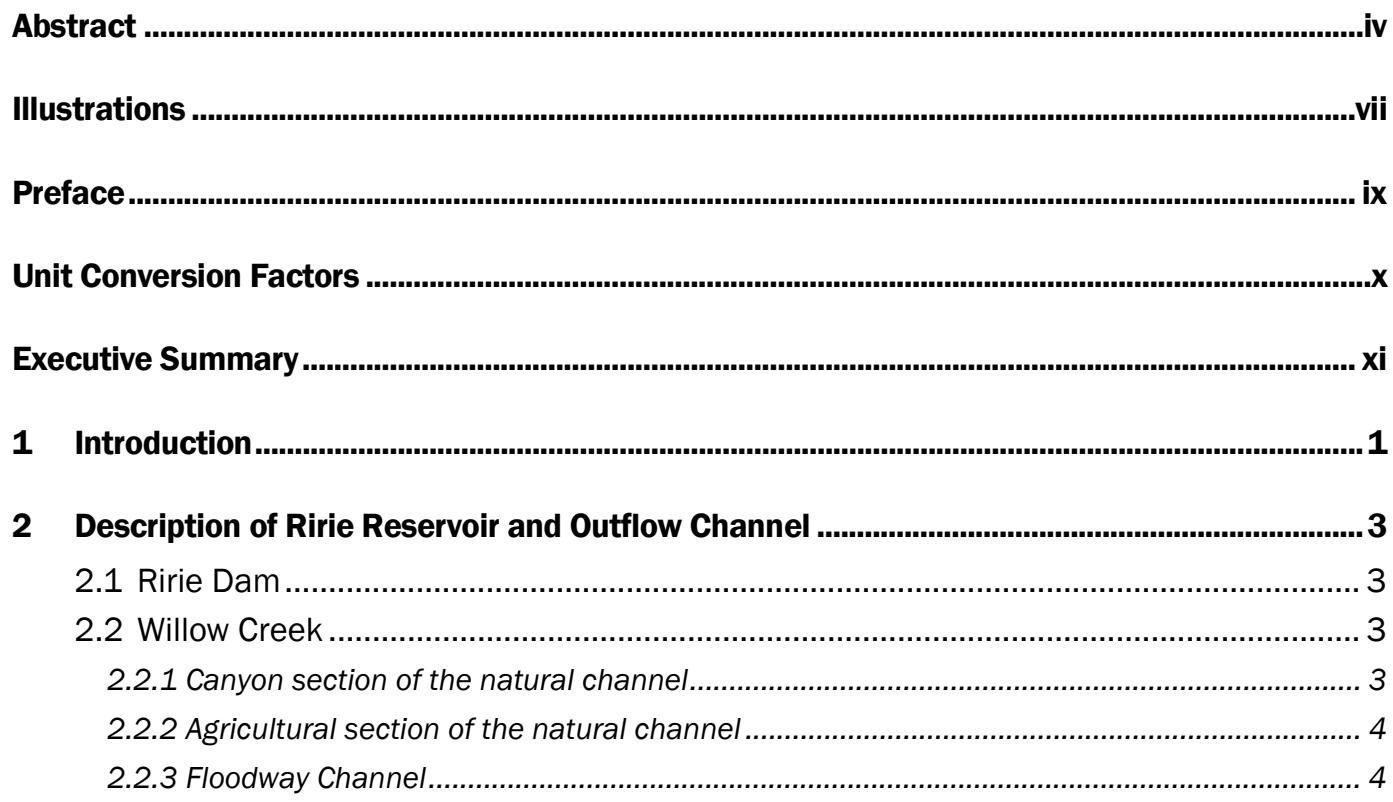

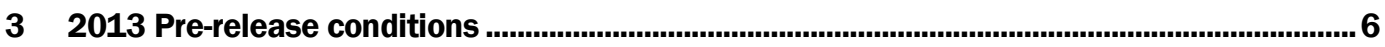

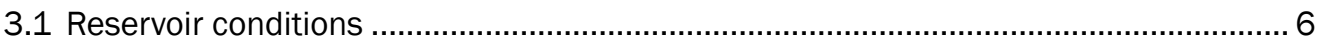

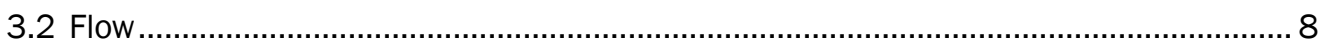

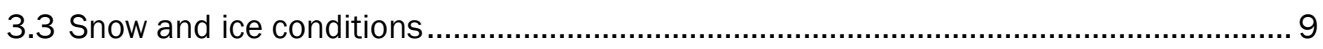

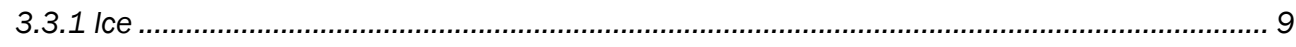

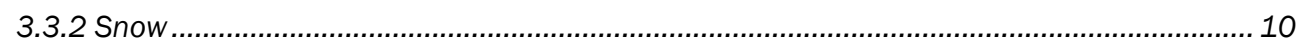

42013 Release Test Observations....................................................................................................22

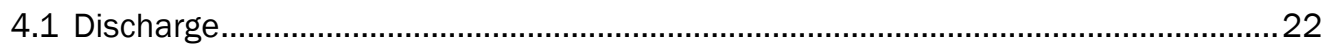

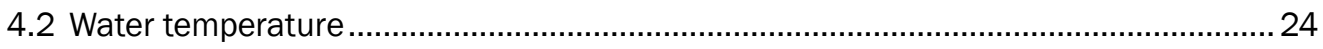

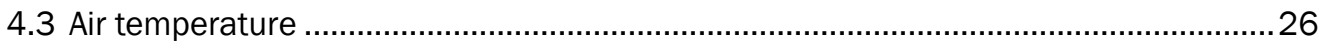

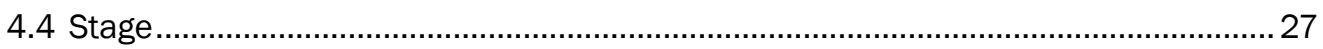

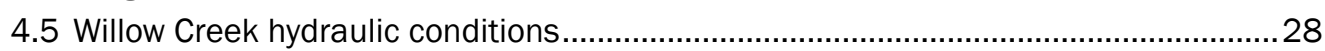

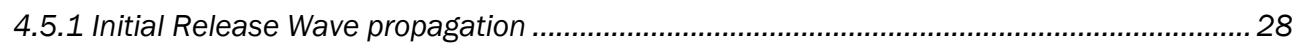

4.5.2 Propagation of discharge modifications made after the Initial Release Wave ....................29

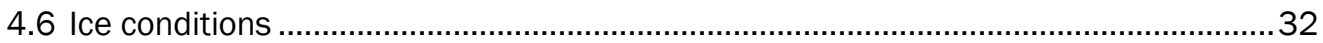

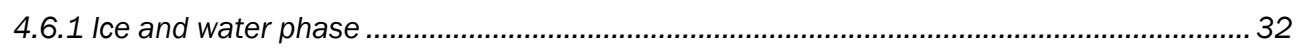

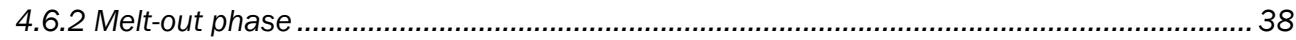

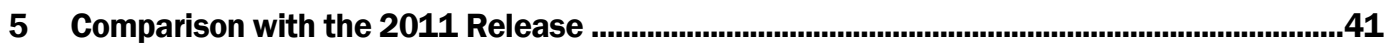

6 Discussion of 2013 Results ...............................................................................................45

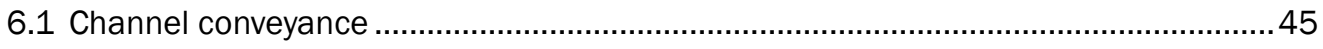

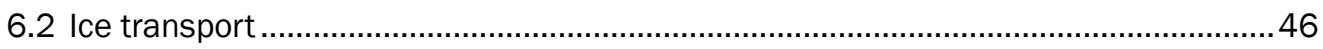


7 Recommendations for Future Wintertime Releases ............................................................48

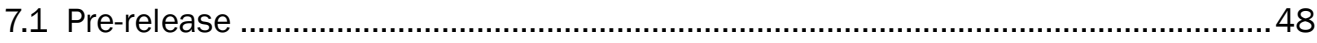

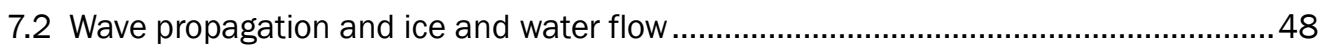

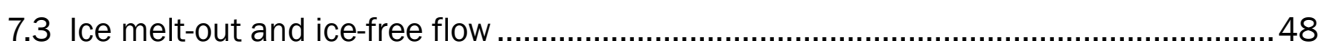

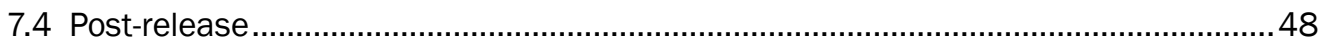

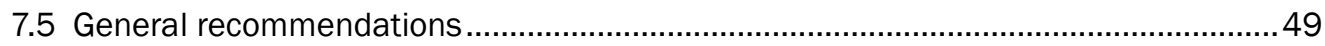

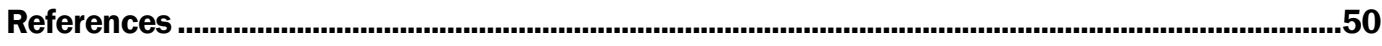

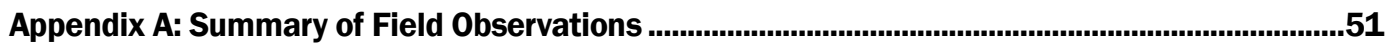

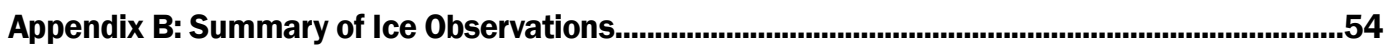

Report Documentation Page 


\section{Illustrations}

\section{Figures}

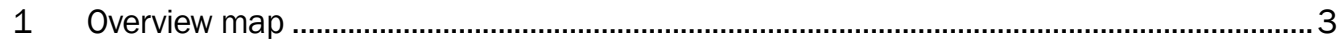

2 Upstream reaches ...........................................................................................................

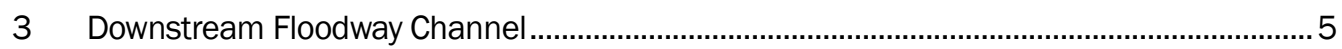

4 Ririe Dam reservoir water level over the winter........................................................................

5 Ririe Dam reservoir water temperatures with depth ......................................................... 7

6 Ririe Dam discharges from 1 August 2012 until the end of the Release Test ..................... 8

$7 \quad$ Ice cover in place upstream of $115^{\text {th }}$ St. Bridge prior to release .......................................... 9

8 Snow depth and channel cross section at the $115^{\text {th }}$ St. Bridge ........................................12

9 Looking upstream from the $115^{\text {th }}$ St. Bridge prior to release ...........................................12

10 Snow depth and channel cross section at the $95^{\text {th }}$ St. Bridge........................................13

11 Looking upstream from the 95 $5^{\text {th }}$ St. Bridge prior to release ..............................................13

12 Snow depth and channel cross section at the $85^{\text {th }}$ St. Bridge ..........................................14

13 Looking upstream from the 85th St. Bridge prior to release..............................................14

14 Snow depth and channel cross section downstream of the Bifurcation .............................15

15 Looking downstream from the Bifurcation Control Structure prior to release......................15

16 Snow depth and channel cross section near the USGS Gaging Station .............................16

17 Looking downstream from the Willow Creek Head Gates prior to release...........................16

18 Snow depth and channel cross section at the 55th St. Bridge .............................................17

19 Looking downstream from the $55^{\text {th }}$ St. Bridge prior to release............................................17

20 Snow depth and channel cross section at the $35^{\text {th }}$ St. Bridge...........................................18

21 Looking downstream from the $35^{\text {th }}$ St. Bridge prior to release..........................................18

22 Snow depth and channel cross section at the $15^{\text {th }}$ St. Bridge ............................................19

23 Looking downstream from the $15^{\text {th }}$ St. Bridge prior to release............................................19

24 Snow depth and channel cross section at the $5^{\text {th }}$ St. Bridge .............................................20

25 Looking downstream from the $5^{\text {th }}$ St. Bridge prior to release ............................................20

26 Snow depth and channel cross section at the outfall .......................................................21

27 Looking upstream from the mouth of the Floodway Channel during release......................21

28 Observed discharge at the USGS gages during the Release Test .....................................24

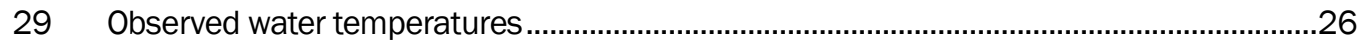

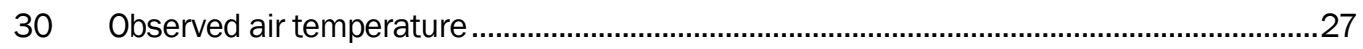

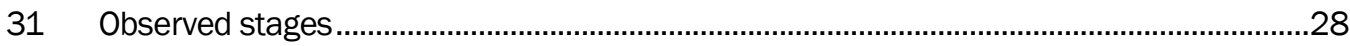

32 Observed Initial Release Wave, flow changes, and the advance of the melt-out

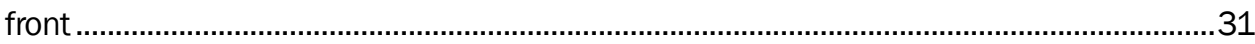

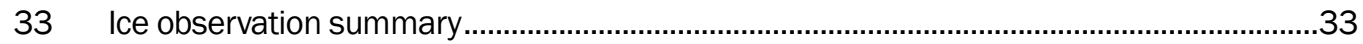

34 Ice cover upstream of the $115^{\text {th }}$ St. Bridge after passage of the IRW.................................34 
35 Evolution of the hanging ice dam downstream of the Ferguson Bridge ..............................35

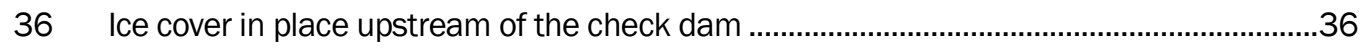

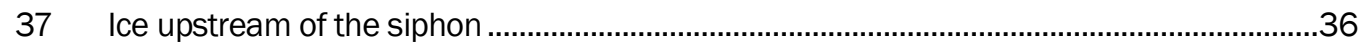

38 Willow Creek flow through Snake River ice cover, 12 February 2012 at 1630 ...................38

39 Looking upstream from the $115^{\text {th }}$ St. Bridge after the Release Test. ..................................40

40 Looking upstream from the mouth of the Floodway Channel after the Release Test.

41 Daily average air temperatures leading up to the releases of 2011 and $2013 \ldots \ldots \ldots \ldots \ldots . . . . .42$

42 Daily discharge from Ririe Reservoir leading up to the releases .........................................43

43 Snow remaining in Floodway Channel at $25^{\text {th }}$ St. Bridge after the 2011 release ...............44

\section{Tables}

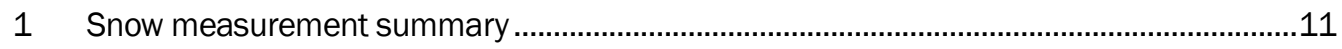

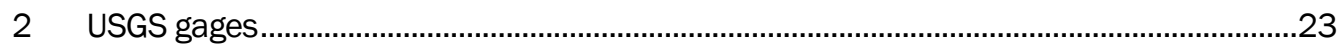

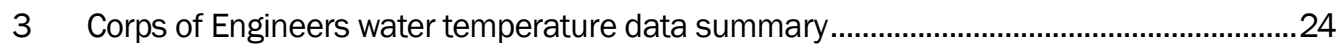

4 Summary of the Initial Release Wave propagation.........................................................29

5 Summary of propagation of discharge modifications made after the IRW.........................31

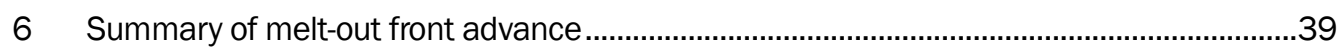

7 Comparison of daily maximum and minimum temperatures in 2011 and 2013...............42

8 Comparison of Initial Release Wave propagation in 2011 and 2013................................43

9 Percentage of each surveyed cross section area blocked by snow with height above the channel invert 


\section{Preface}

This study was conducted for the Walla Wall District of the Corps of Engineers.

The work was performed by Dr. Steven F. Daly and Dr. Meredith Carr (Remote Sensing/ GIS and Water Resources Branch, Timothy Pangburn, Chief), US Army Engineer Research and Development Center, Cold Regions Research and Engineering Laboratory (ERDC-CRREL); and Stephen Hall and J eremy Giovando, Walla Walla District, US Army Corps of Engineers.

At the time of publication, Dr. J ustin Berman was Chief of the Research and Engineering Division of ERDC-CRREL, the Deputy Director was Dr. Lance Hansen, and the Director was Dr. Robert Davis. COL Kevin J. Wilson was the Commander of ERDC, and Dr. J effery P. Holland was the Director.

Keith Brooks and Michael W. Beus of the Bureau of Reclamation, Peter Cooper of the Idaho Department of Water Resources, and USGS-Idaho Falls Field Office contributed to this study. 


\section{Unit Conversion Factors}

\begin{tabular}{|l|l|l|}
\hline Multiply & By & To Obtain \\
\hline acres & $4,046.873$ & square meters \\
\hline acre-feet & $1,233.5$ & cubic meters \\
\hline cubic feet & 0.02831685 & cubic meters \\
\hline degrees Fahrenheit & $(\mathrm{F}-32) / 1.8$ & degrees Celsius \\
\hline feet & 0.3048 & meters \\
\hline inches & 0.0254 & meters \\
\hline miles (US statute) & $1,609.347$ & meters \\
\hline
\end{tabular}




\section{Executive Summary}

A Release Test consisting of three days of outflows from Ririe Dam into Willow Creek was conducted 10- 13 February 2013. The flow out of Ririe Dam prior to the Release Test was zero. The release schedule was an initial release of $150 \mathrm{cfs}$ for $28 \mathrm{hr}$ ( 10 February 2013 at 1450 until 11 February at 1920); a rapid increase to $300 \mathrm{cfs}$, which was held for $14.5 \mathrm{hr}$ (11 February at 1920 until 12 February at 0950); and another rapid increase to 500 cfs, which was held for $24 \mathrm{hr}$ (12 February at 0950 until 13 February at 1000). The flow was then shut off.

Prior to the Release Test, the temperature of Ririe Reservoir was measured; and the snow and ice conditions in Willow Creek were documented. Snow blocked less than $25 \%$ of the Outflow Channel cross section area at a stage height of $4.5 \mathrm{ft}$ at any section surveyed.

Detailed measurements of the water temperature, stage, and discharge along the Willow Creek channel were made throughout the test. The dynamic ice conditions in the Willow Creek channel were observed.

The Initial Release Wave or subsequent flow did not significantly remove, dislodge, or erode snow in the channel prior to the release. This required the water to travel on top of the snow and around any snow drifts in place. The snow was melted out only after the thermal melt-out front had advanced downstream the length of the Willow Creek channel.

Floating slush ice was observed to collect at the Ferguson Bridge; at the check dam upstream of the Bifurcation; and to a lesser extent, at the Siphon.

A melt-out front advanced downstream as the relatively warm water in the outflow of Ririe Dam melted out the snow and ice in the channel. The melt-out front advanced to the downstream end of Willow Creek in $59 \mathrm{hr}$ and $15 \mathrm{~min}$. After this time, the entire Willow Creek channel was effectively ice free.

There was no out-of-bank flooding during the Release Test. 
A series of recommendations for action during future releases was prepared based on these results and the results of a release in February 2011. 


\section{Introduction}

The US Army Corps of Engineers (Corps) Walla Walla District (NWW) is currently evaluating flood control operations at Ririe Reservoir to allow increased storage over the winter season. This winter season carryover would replace some portion of the early winter season flood control space of the reservoir. This would require the option to conduct wintertime releases of retained water so as not to increase the downstream flood risk. At this time, there is little experience with winter releases into dry, snow filled channels. An experimental wintertime release from Ririe Dam in 2011 resulted in minor flooding that required active mechanical removal of snow and ice from the channel in response. Before wintertime releases can become an operational procedure at Ririe Dam, it is important to understand the potential problems and their solutions. To provide insight into the problems associated with wintertime releases, the Corps, in cooperation with the Bureau of Reclamation, the United States Geological Survey (USGS), the Idaho Department of Water Resources, and others, conducted a Release Test 10-13 February 2013. This test consisted of three days of outflows from Ririe Dam into Willow Creek. The flow out of Ririe Dam prior to the Release Test was zero. The release schedule was an initial release of 150 cfs for $28 \mathrm{hr}$ (10 February 2013 at 1450 until 11 February at 1920); a rapid increase to $300 \mathrm{cfs}$, which was held for $14.5 \mathrm{hr}$ (11 February at 1920 until 12 February at 0950); and another rapid increase to 500cfs, which was held for $24 \mathrm{hr}$ (12 February at 0950 until 13 February at 1000). The flow was then shut off.

A team of observers from the Corps of Engineers, the Bureau of Reclamation, the United States Geological Survey, and the Idaho Department of Water Resources recorded the conditions in Willow Creek and in the Ririe Reservoir prior to and during the Release Test. Prior to the Release Test, they measured the temperature of Ririe Reservoir and documented the snow and ice conditions in Willow Creek. The team observed and documented the propagation of the Initial Release Wave (IRW) down the dry, partially snow-filled Willow Creek channel and made detailed measurements of the water temperature, stage, and discharge along the Willow Creek channel throughout the test. Additionally, they observed the dynamic ice conditions in the Willow Creek channel. 
In general, the snow in the channel prior to the Release Test remained in place as the IRW propagated down the channel, requiring the water to travel on top of the snow and around any snow drifts in place. Slush ice, observed along most of the lower reach of Willow Creek, moved with the channel flow velocity but collected and built up at specific locations. The temperature of the water released from Ririe Dam was above $39^{\circ} \mathrm{F}\left(3.9^{\circ} \mathrm{C}\right)$ at the outlet of the dam throughout the test. As this warmer water propagated downstream, it melted the ice and snow in the channel, lowering the flow temperature to $32^{\circ} \mathrm{F}\left(0^{\circ} \mathrm{C}\right)$. The water temperature at any location increased above $32^{\circ} \mathrm{F}\left(0^{\circ} \mathrm{C}\right)$ when all the snow and ice upstream of that location had melted out. The melt-out phase of the test began at each channel location when water temperature rose above $32^{\circ} \mathrm{F}\left(0^{\circ} \mathrm{C}\right)$. By the end of the Release Test, all the snow and ice had melted throughout the entire Willow Creek channel, leaving the entire Willow Creek snow and ice free.

The objectives of this report are to document the conditions in Ririe Reservoir and Willow Creek prior to and during the Release Test, to compare the 2013 Release Test with the 2011 release, and to make recommendations regarding future wintertime releases from Ririe Dam and operation of Willow Creek. 


\section{Description of Ririe Reservoir and Outflow Channel}

\subsection{Ririe Dam}

Constructed by the Corps from 1970 to 1977, the Ririe Dam and Reservoir project is approximately 17 miles northeast of the town of Idaho Falls, ID (Fig. 1). The dam is an earth and rockfill structure, 253-ft high and 1070-ft long (US Department of Interior 2013). The reservoir impounded by the dam has a total capacity of 100,500 acre- $\mathrm{ft}$ with an active storage of 90,500 acre-ft. This active storage includes 10,000 acre-ft of exclusive flood control and 80,541 acre-ft of joint use storage (irrigation and flood control). The Corps formally transferred the project to Reclamation through a memorandum of agreement effective 14 October 1976. The Corps continues to manage the flood control operations of the Ririe Project based on Section 7 of the Flood Control Act of 1944.

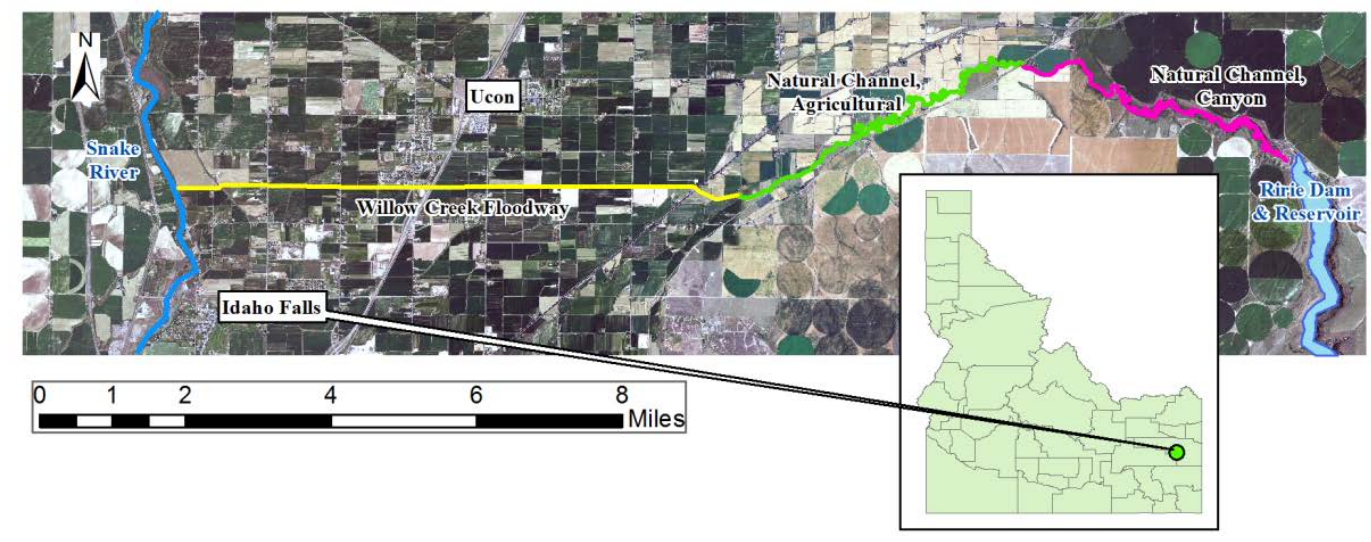

Figure 1. Overview map.

\subsection{Willow Creek}

\subsubsection{Canyon section of the natural channel}

The outlet of Ririe Dam enters immediately into Willow Creek. Willow Creek then meanders approximately 6.7 miles downstream through a canyon that provides no vehicular access to the creek (Fig. 2). In this report, this section of Willow Creek is referred to as "natural" although agricultural activity has modified some locations of the creek in this section, especially along the south bank. This canyon section of the natural channel ends at the $115^{\text {th }}$ St. Bridge. This reach of Willow Creek can be accessed on- 
ly at its upstream end at the Ririe Dam and its downstream end at the $115^{\text {th }}$ St. Bridge.

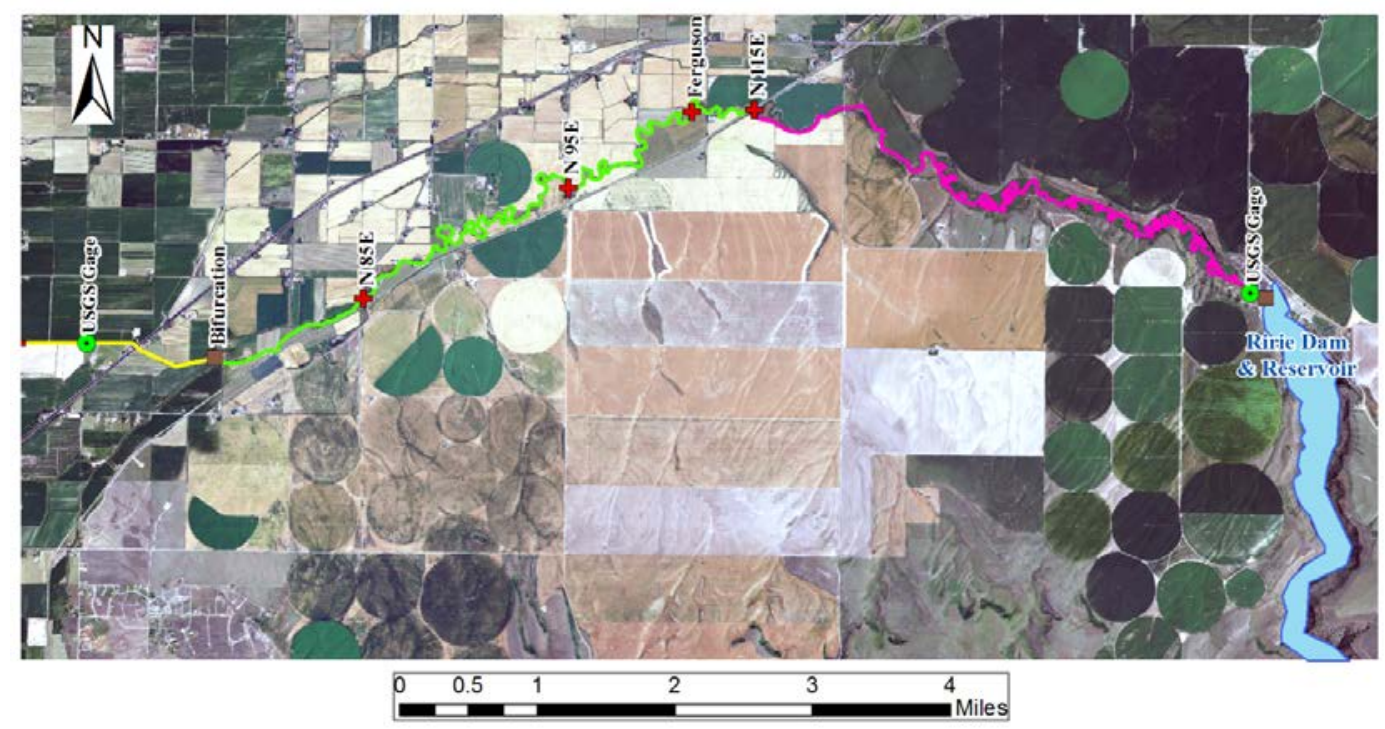

Figure 2. Upstream reaches.

\subsubsection{Agricultural section of the natural channel}

Downstream of the 115 th St. Bridge, Willow Creek flows continuously through agricultural land (Fig. 2). The meandering of the creek through this section maintains a natural appearance, but agricultural activity has modified the channel banks over the years. This section extends downstream to the Bifurcation. The control gates located at the Bifurcation control the flow into the downstream reaches of Willow Creek and into Sand Creek. Five low-head weirs were indentified in this reach based on satellite imagery. Only the weir farthest downstream was inspected during the course of the test. This weir is an uncontrolled rubble stone check dam that crosses Willow Creek approximately 0.4 miles upstream of the Bifurcation. The check dam has a drop of approximately $3 \mathrm{ft}$. This reach of Willow Creek can be accessed at its upstream end at the 115th St. Bridge, the Ferguson Road Bridge, the 95 ${ }^{\text {th }}$ St. Bridge, the $85^{\text {th }}$ St. Bridge, and the Bifurcation.

\subsubsection{Floodway Channel}

The Floodway Channel is a constructed trapezoidal channel designed to divert flow from Willow Creek to reduce the flow through Idaho Falls and the area northeast of the city (Fig. 3). The Floodway Channel begins on Willow Creek just downstream from the point where Sand Creek branches 
from Willow Creek. This location is referred to as the Bifurcation (US Department of the Interior 2013). The headworks of the Bifurcation allows water to be diverted to either the Floodway Channel or Sand Creek. The Floodway Channel extends directly west 7.8 miles and enters the larger natural channel of the Snake River 4.5 miles north of Idaho Falls. The Willow Creek Floodway Channel can be accessed at a number of locations listed in Table 1.

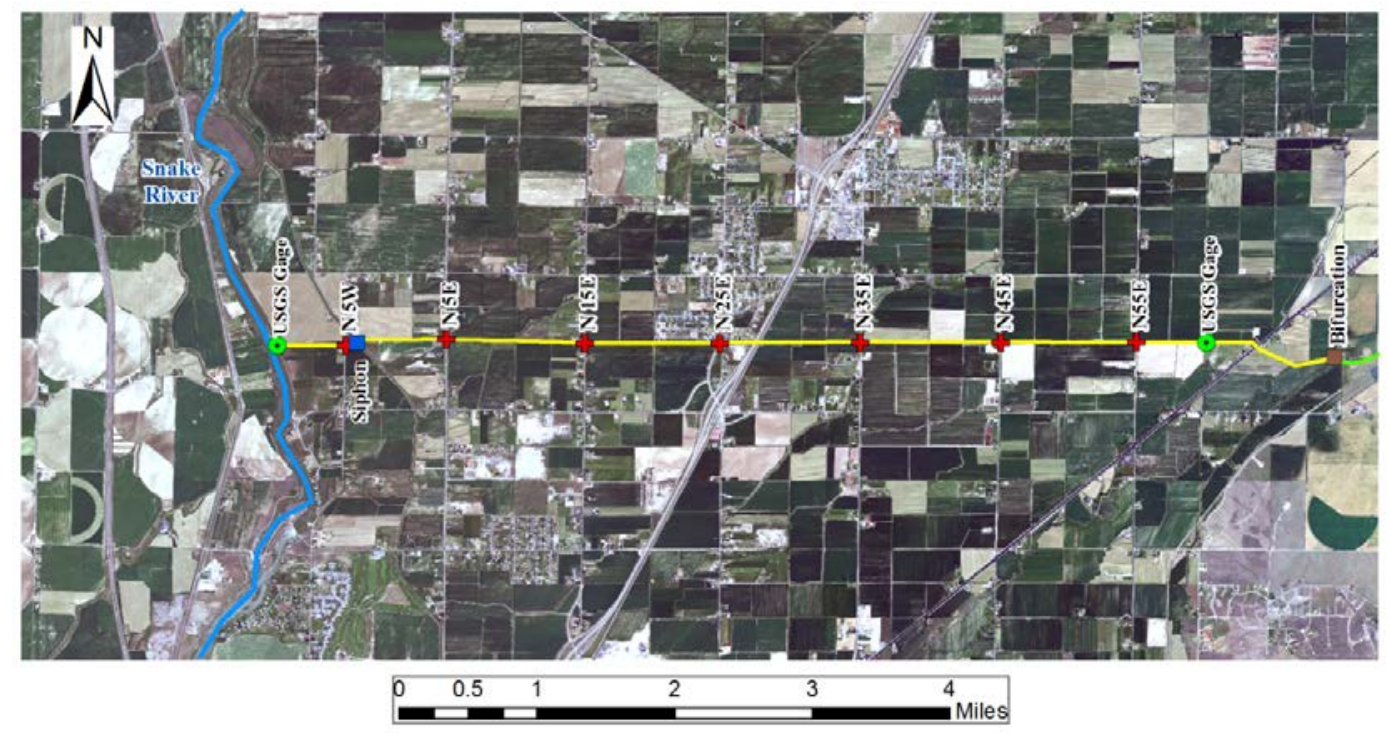

Figure 3. Downstream Floodway Channel. 


\section{Pre-release conditions}

\subsection{Reservoir conditions}

The Ririe Reservoir water level increased steadily throughout the winter of 2012-2013, as shown in Figure 4. The rate of increase was about $1 \mathrm{ft}$ every 15 days. Recording sensors measured reservoir temperatures hourly from 24 November 2012 through 10 February 2013. They recorded the water temperatures at $15 \mathrm{ft}$ intervals between 5000 and $5070 \mathrm{ft}$, and the data were downloaded after the sensors were removed from the reservoir. The temperature sensors were located on an instrumentation string that was suspended in the reservoir at the outlet structure of the dam. The Bureau of Reclamation removed the instrumentation string from the reservoir immediately before the Release Test was started. Given that the instrumentation string was frozen into the reservoir ice cover and that it was necessary to melt the ice surrounding the instrumentation string to remove the string, it is likely that the elevation of the temperature sensors changed over the course of the winter in response to the increase in the reservoir water level.

Figure 5 shows the recorded water temperatures. In November and through mid-December, the water temperatures decreased in response to heat loss from the reservoir surface to the atmosphere. The initial decrease in water temperature was very uniform throughout the depth of the reservoir. It is expected that the water temperature would be very uniform throughout the reservoir depth when the water temperature was at its density maximum of $39.2^{\circ} \mathrm{F}\left(4^{\circ} \mathrm{C}\right)$. As the reservoir continued to cool, the water temperatures throughout the depth reflected the balance between the stratification caused by the density differences of water because of temperature differences and the mixing from any wind stress applied at the water surface. Stratification is apparent by about 25 December with the warmest and most dense water near the bottom. This stratification increased as the surface layers continued to cool, and the water at depth remained more or less at a constant temperature. The reasons for some of the small scale variations in the water temperature after $1 \mathrm{~J}$ anuary are not known. Certainly, movement of the instrumentation string by currents, the rise of the reservoir surface elevation lifting the string frozen into the surface ice cover, or other factors may have had an impact. In any case, it is apparent that at the start of the Release Test on 10 February 2013, there 
was a large reserve of relatively warm water available in Ririe Reservoir. As a result of this reserve of warm water, the temperature of the outflow from Ririe Reservoir remained above $38.4^{\circ} \mathrm{F}\left(3.54^{\circ} \mathrm{C}\right)$ throughout the $\mathrm{Re}$ lease Test.

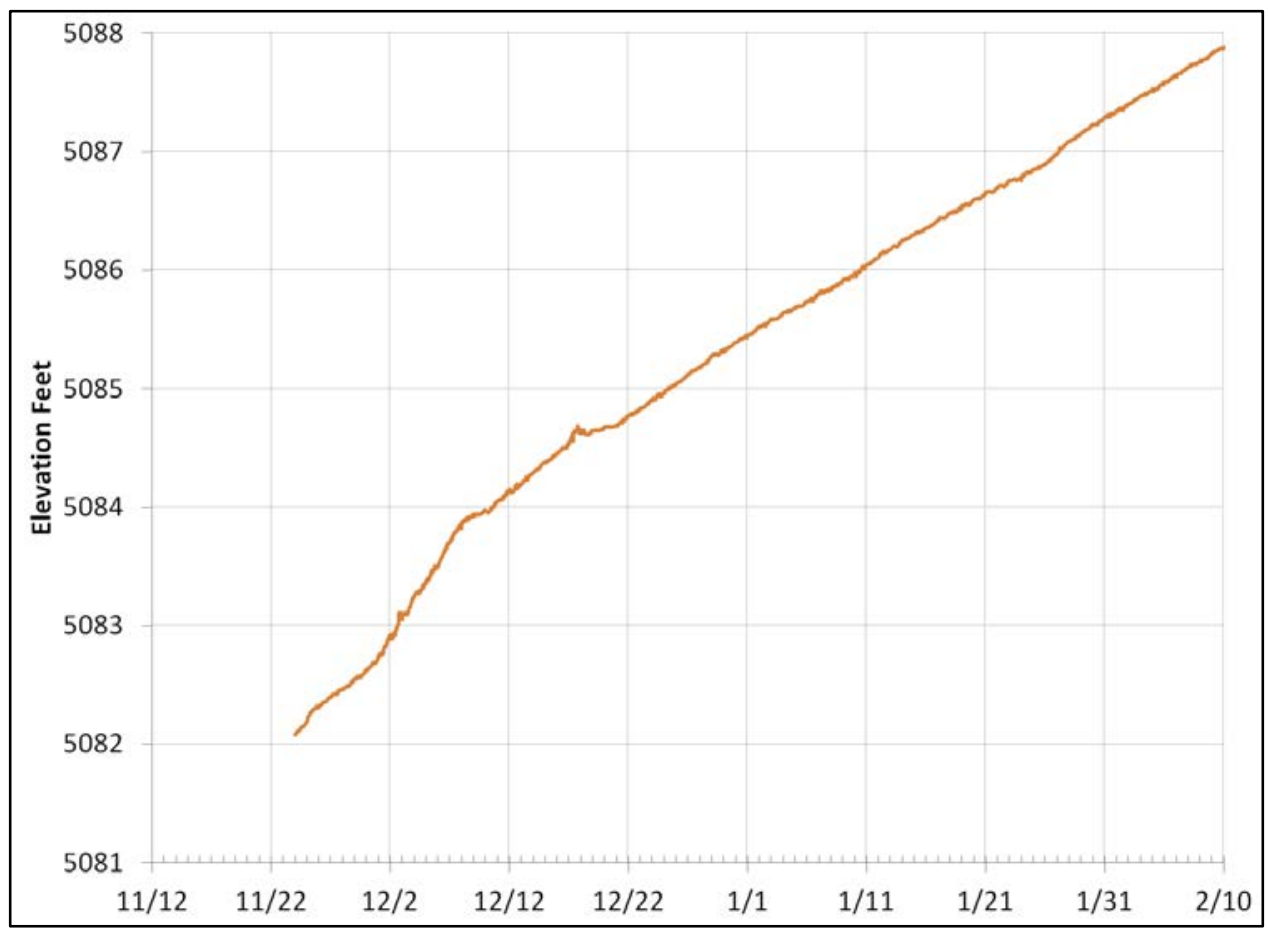

Figure 4. Ririe Dam reservoir water level over the winter.

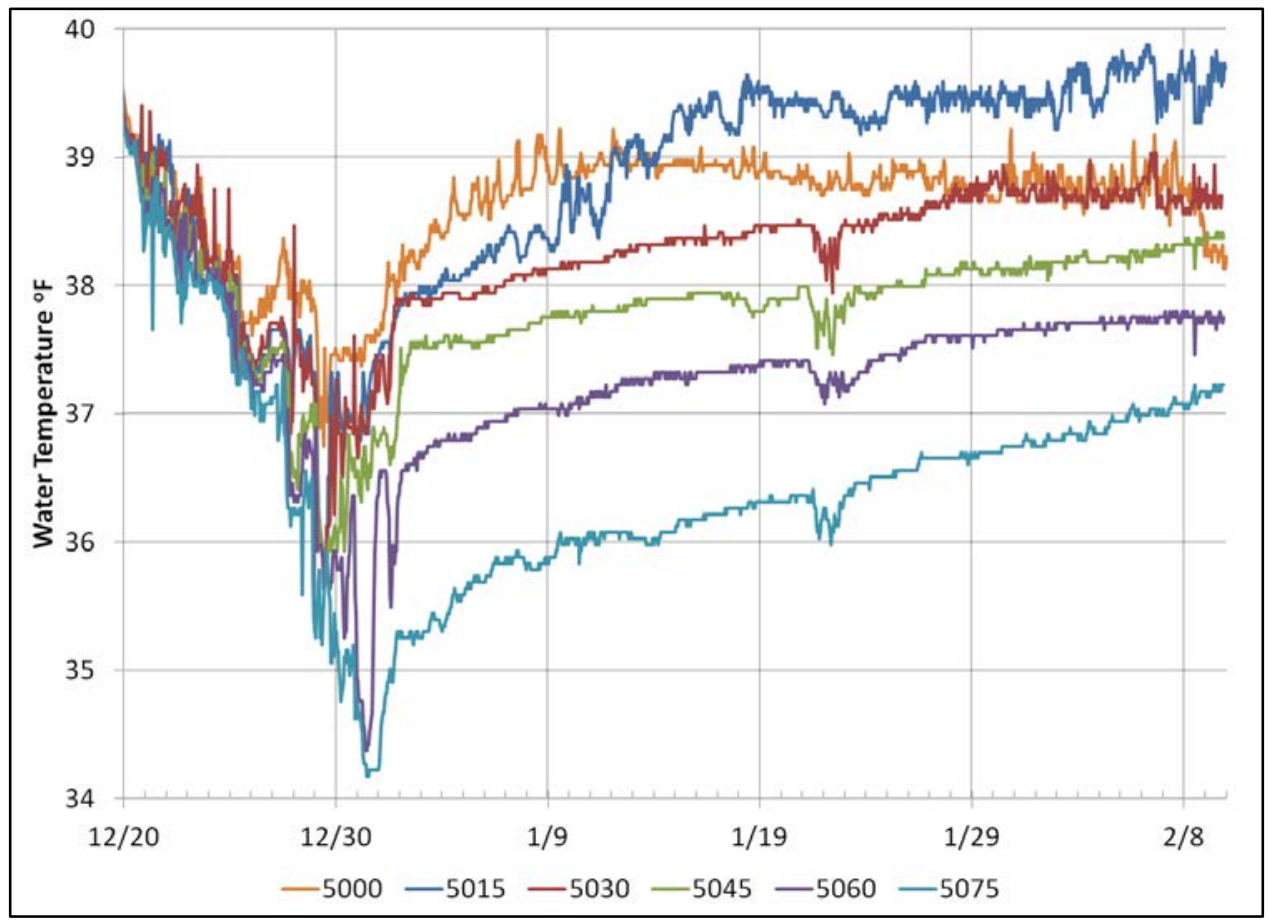

Figure 5. Ririe Dam reservoir water temperatures with depth. 


\subsection{Flow}

Figure 6 shows the releases from Ririe Reservoir throughout the fall and winter of 2012-2013. The releases from the reservoir were stopped on 19 November 2012 and were not started again until the Release Test started on 10 February 2013. Observations made on 8- 10 February 2013 in the Willow Creek channel prior to the arrival of the release flow determined that there was a small amount of flow in the canyon section of the natural channel. This flow probably originated partly from leakage around the Ririe Dam outflow gates and partly from ground water inflow. A small amount of leakage flow was observed at the Ririe Dam outlet prior to the Release Test. This flow allowed surface ice to form in this reach, as described in the next section. Some open areas upstream of the 115 th St. Bridge indicated groundwater inflow into the system. There was no flow observed at the $115^{\text {th }}$ St. Bridge. Prior to the Release Test, the channel was completely dry, although snow covered, downstream of the $115^{\text {th }}$ St. Bridge to the Outlet works at the Snake River.

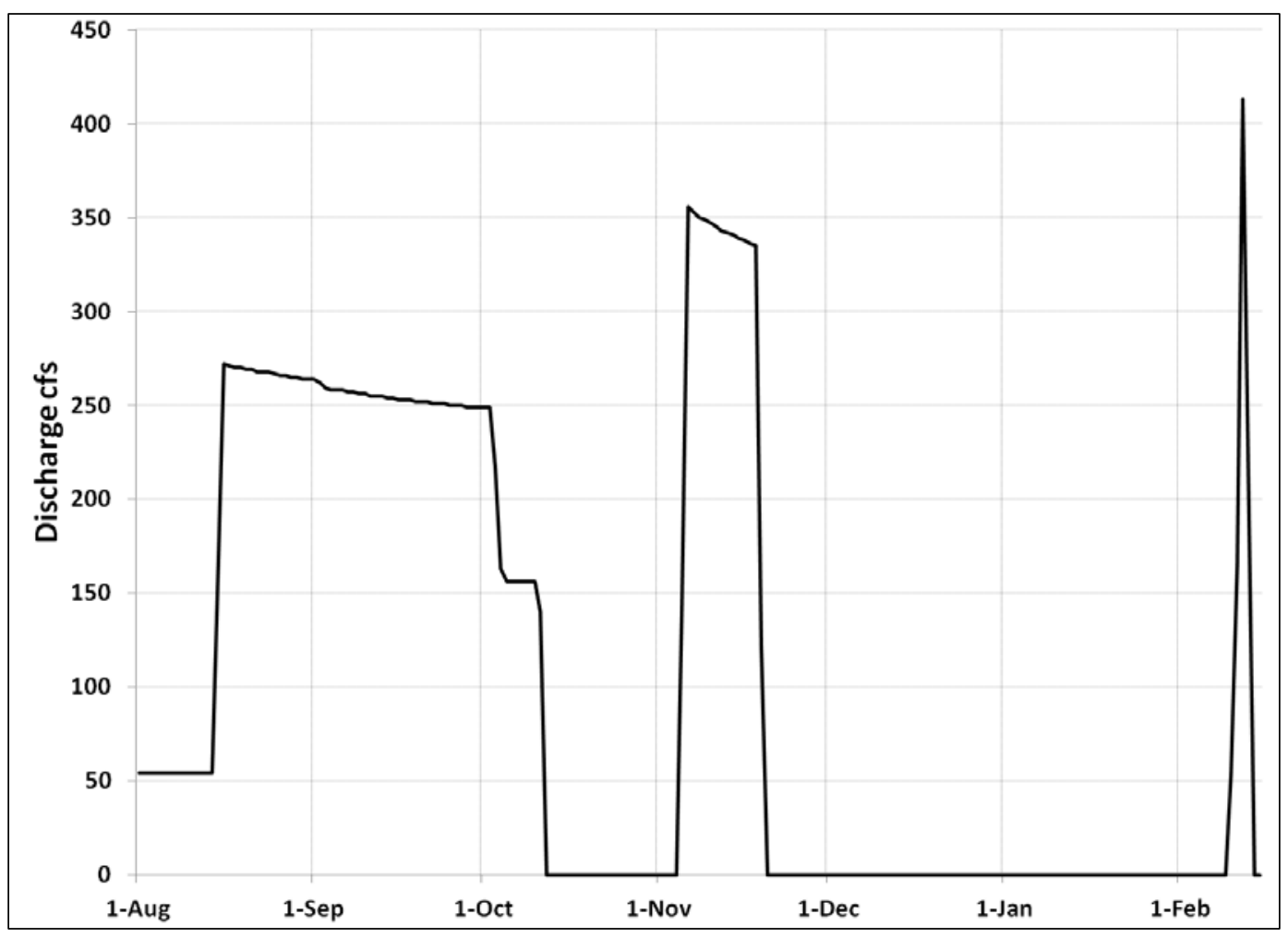

Figure 6. Ririe Dam discharges from 1 August 2012 until the end of the Release Test. 


\subsection{Snow and ice conditions}

\subsubsection{Ice}

As a result of the flow in the canyon section of the Willow Creek natural channel, an ice cover was in place on Willow Creek starting about 0.25 miles upstream of the $115^{\text {th }}$ St. Bridge and extending an unknown distance upstream. Holes drilled through the ice cover for ice fishing showed an ice thickness of 16 in. near the downstream end of the ice cover. A survey done on foot was conducted over a distance of approximately 1 mile upstream of the 115th St. Bridge (Fig. 7). Willow Creek ice covered over this entire 1mile reach. Approximately 0.5 upstream of the $115^{\text {th }}$ St. Bridge were the remains of a snow avalanche. The avalanche resulted from snow accumulation on a 50 to $75 \mathrm{ft}$ bluff on the southern bank of Willow Creek. The avalanche appeared to have broken through the channel ice cover and filled approximately half the channel. The upstream extent of the ice cover was not determined, although an ice cover was observed approximately 0.25 miles downstream of Ririe Dam. No ice cover was observed downstream of the $115^{\text {th }}$ St. Bridge.

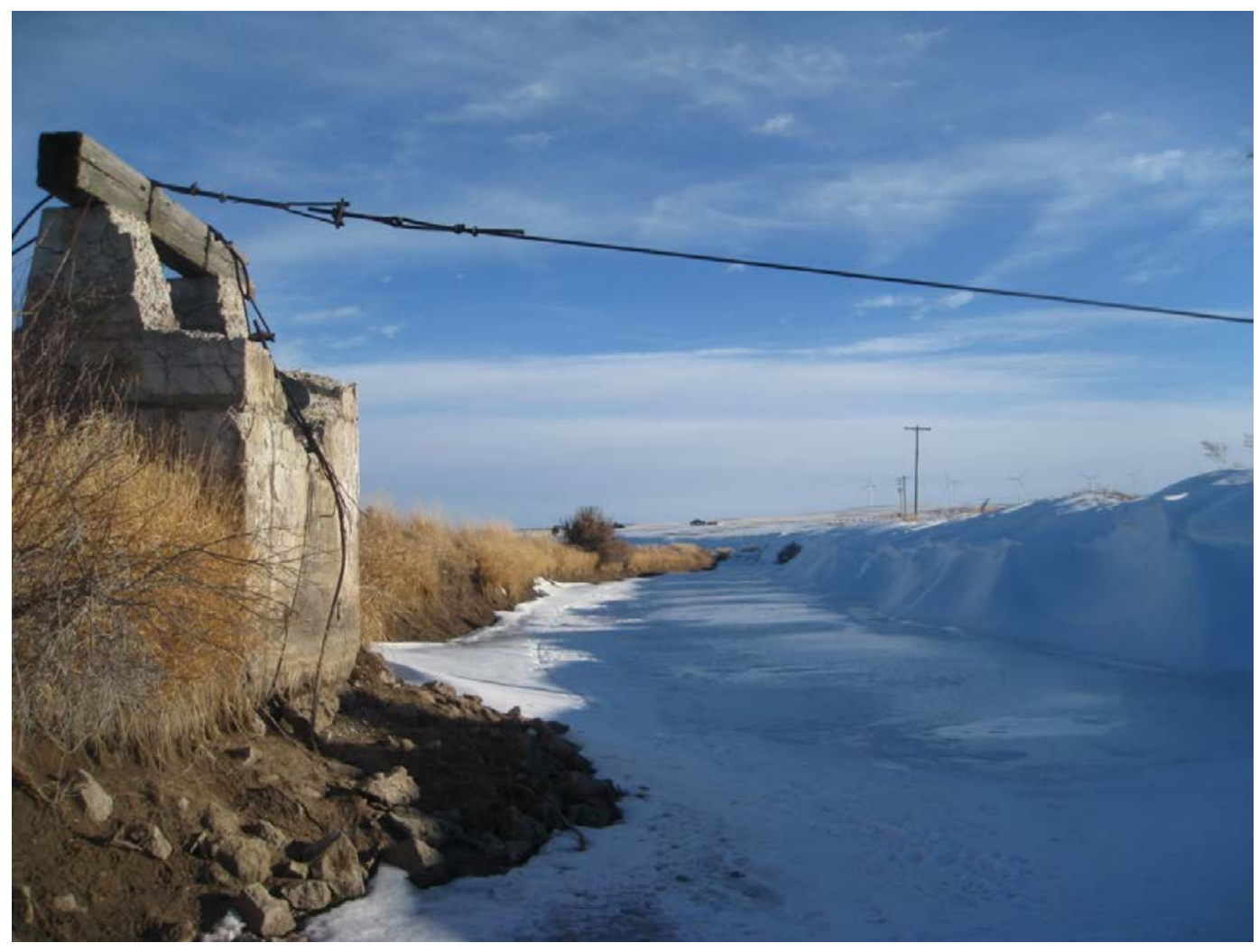

Figure 7. Ice cover in place upstream of $115^{\text {th }}$ St. Bridge prior to release. 


\subsubsection{Snow}

Table 1 shows the snow density and snow distribution surveyed at a number of locations. The snow surface was crusty at most locations. The snow density was measured using a CRREL snow density tube (Ueda et al. 1975). The snow density tube has a volume of $500 \mathrm{~cm}^{3}$. At each location, the tube was driven into the snow cover until completely full. The end of the snow tube was cleaned flat using a beveled flat plate, and rubber caps were then placed on the end to hold the snow in the tube. The tube, snow, and rubber caps were then weighed using a gram scale. The tare weight of the tube and caps was subtracted from the total weight to determine the weight of the snow. The density was found as the ratio of the snow mass to the snow volume. Table 1 lists these results. The measured snow density ranged between 0.260 and $0.318 \mathrm{~g} \mathrm{~cm}^{-3}$.

Figures 8 through 27 show the snow distribution across the channel at each cross section. (Note: the plots of the snow distribution are shown left to right looking downstream.) The snow depth was measured at intervals across the channel. In addition to the snow depth, the elevation of the channel substrate was measured relative to the channel invert at the same intervals. In general, the snow distribution across the channel was very non-uniform with the greater mass of snow accumulated on the south bank of the channel. In some locations, a snow cornice had formed at the top of the south bank. The northern bank of the channel was more or less completely snow free, especially throughout the Willow Creek Floodway Channel. The non-uniform distribution of the snow was probably the result of drifting from the prevailing winds combined with snow ablation on the south-facing northern channel bank. 
Table 1. Snow measurement summary.

\begin{tabular}{|c|c|c|c|c|}
\hline \multicolumn{5}{|c|}{8 February 2013} \\
\hline Time & Reach & Location & Action & Snow Density $\left(\mathrm{g} \mathrm{cm}^{-3}\right)$ \\
\hline $0800-1200$ & Floodway & $\begin{array}{l}5^{\text {th }} \text { St. to } \\
\text { Bifurcation }\end{array}$ & Inspection. & \\
\hline 1215-1245 & Ririe Dam & Outlet & Installed temp. probes. & \\
\hline 1318 & Agricultural & $95^{\text {th }}$ St. & Section Survey. & 0.272 \\
\hline 1405 & Agricultural & $85^{\text {th }} \mathrm{St}$. & Section Survey. & 0.280 \\
\hline 1440 & Floodway & $\begin{array}{l}\text { Downstream } \\
\text { (d/s) of } \\
\text { Bifurcation }\end{array}$ & Section Survey. & 0.264 \\
\hline 1507 & Floodway & $\begin{array}{l}\text { Near gaging } \\
\text { station }\end{array}$ & Section Survey. & \\
\hline 1525 & Floodway & $55^{\text {th }}$ St. & Section Survey. Installed temp. probes. & 0.284 (Top left bank) \\
\hline 1610 & Floodway & $\begin{array}{l}\text { 35th St. } \\
\text { (Yellowstone) }\end{array}$ & Section Survey. Installed temp. probes. & 0.260 \\
\hline 1650 & Floodway & $15^{\text {th }}$ St. & Section Survey. Installed temp. probes. & 0.318 (Center channel) \\
\hline 1716 & Floodway & $5^{\text {th }}$ St. West & Section Survey. Installed temp. probes. & 0.278 (Center channel) \\
\hline \multicolumn{5}{|c|}{9 February 2013} \\
\hline Time & Reach & Location & Action & Snow Density \\
\hline 0935 & Floodway & Outfall & Section Survey. & 0.258 \\
\hline \multirow[t]{2}{*}{1010} & Floodway & $15^{\text {th }}$ St. & Installed water level probe. & 0.280 (Center channel) \\
\hline & Floodway & $\begin{array}{l}\text { 35th St. } \\
\text { (Yellowstone) }\end{array}$ & Installed water level probe. & 0.284 \\
\hline 1105 & Floodway & $55^{\text {th }}$ St. & Installed water level probe. & $\begin{array}{l}0.290 \text { (Top left bank) } \\
0.272 \text { (Left bank) } \\
0.268 \text { (Center channel) }\end{array}$ \\
\hline \multicolumn{5}{|c|}{10 February 2013} \\
\hline Time & Reach & Location & Action & Snow Density \\
\hline 1455 & Canyon & $115^{\text {th }}$ St. & $\begin{array}{l}\text { Section Survey. Inspected upstream ice } \\
\text { conditions for } 1 \text { mile. Ice thickness } 16 \text { in. }\end{array}$ & 0.378 (Very crusty) \\
\hline
\end{tabular}




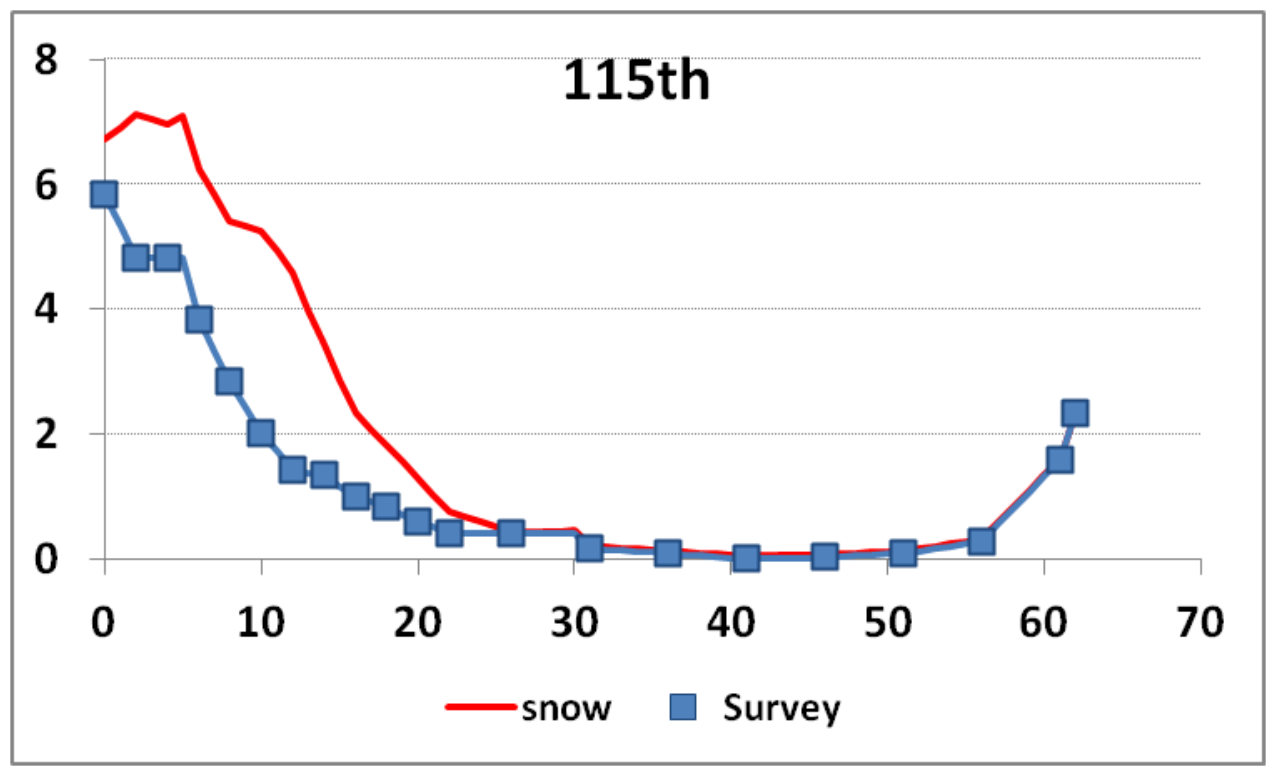

Figure 8. Snow depth and channel cross section (in feet) at the $115^{\text {th }}$ St. Bridge.

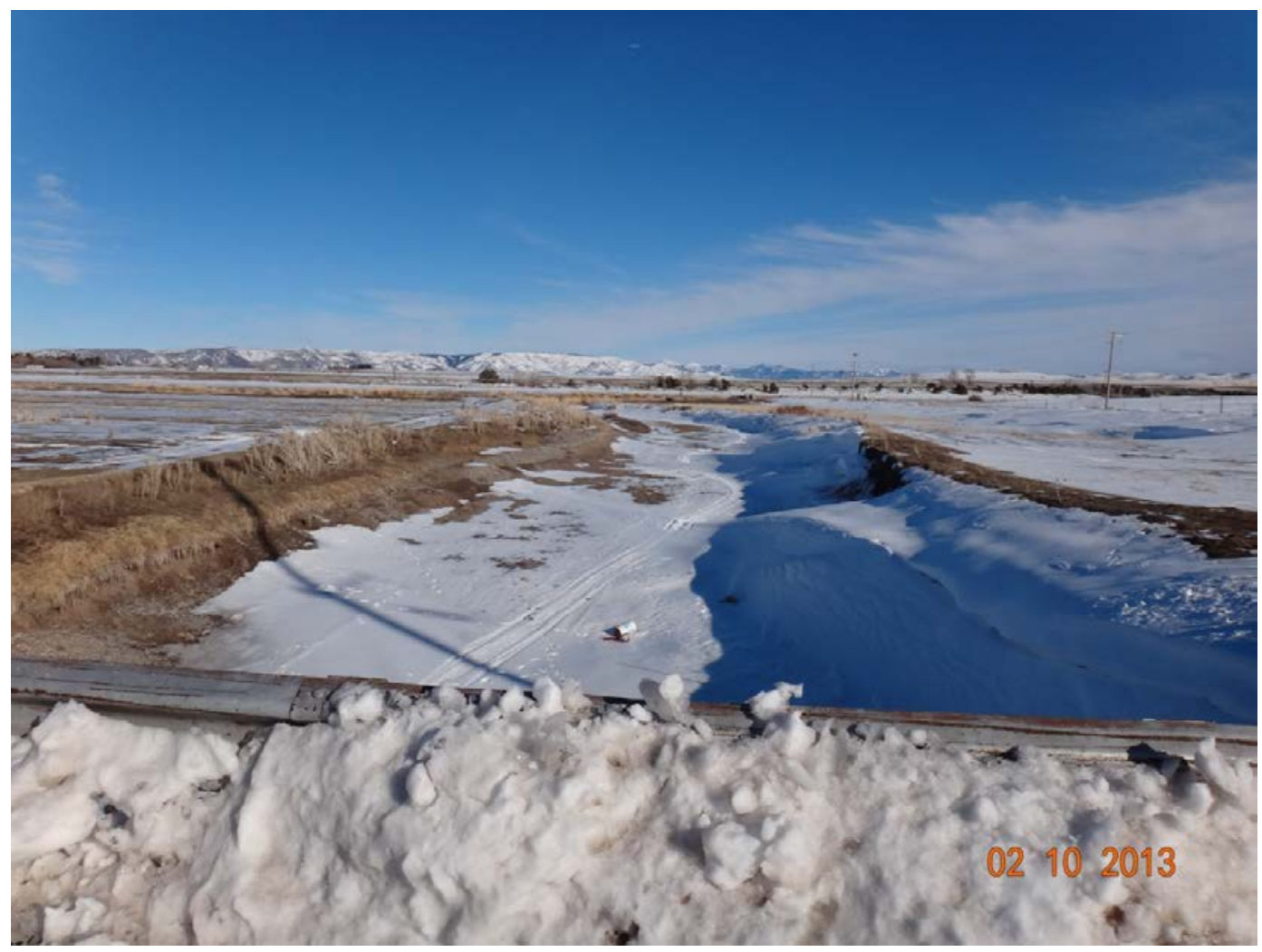

Figure 9. Looking upstream from the $115^{\text {th }}$ St. Bridge prior to release. 


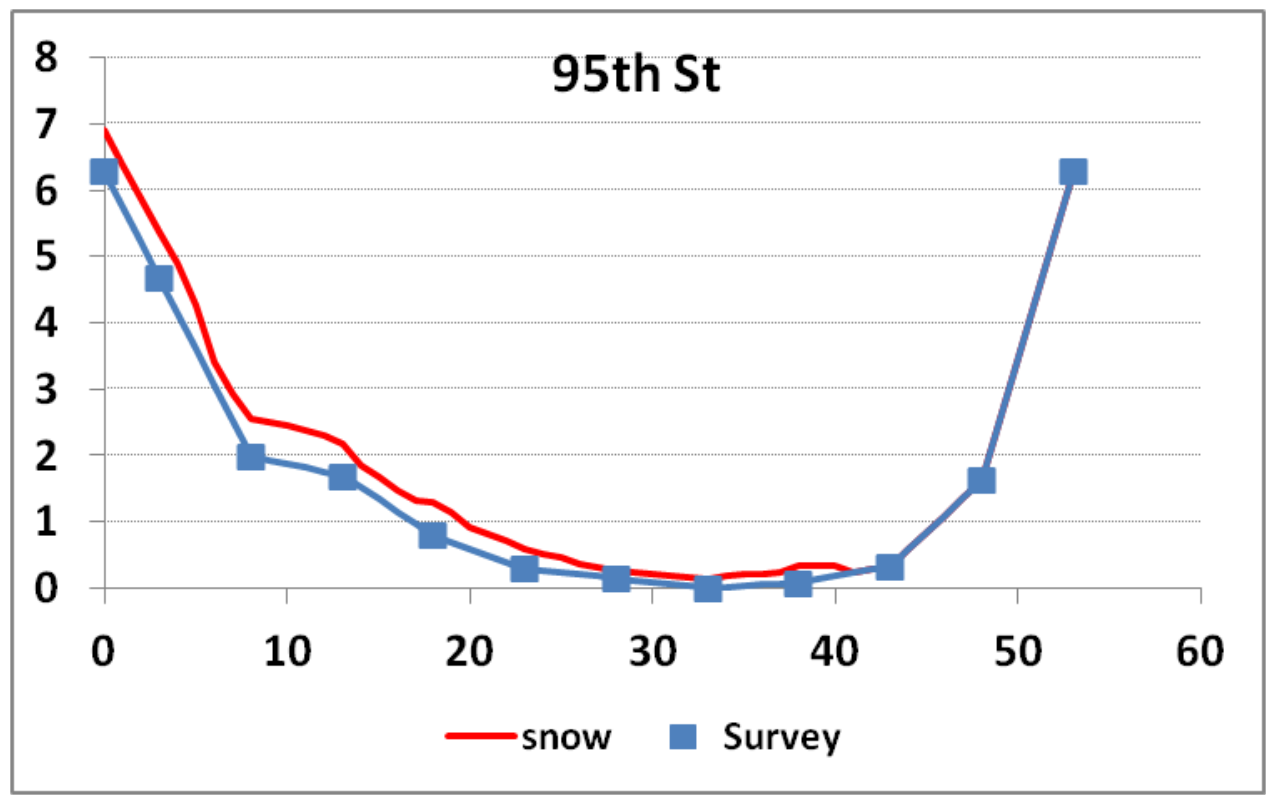

Figure 10. Snow depth and channel cross section (in feet) at the $95^{\text {th }}$ St. Bridge.

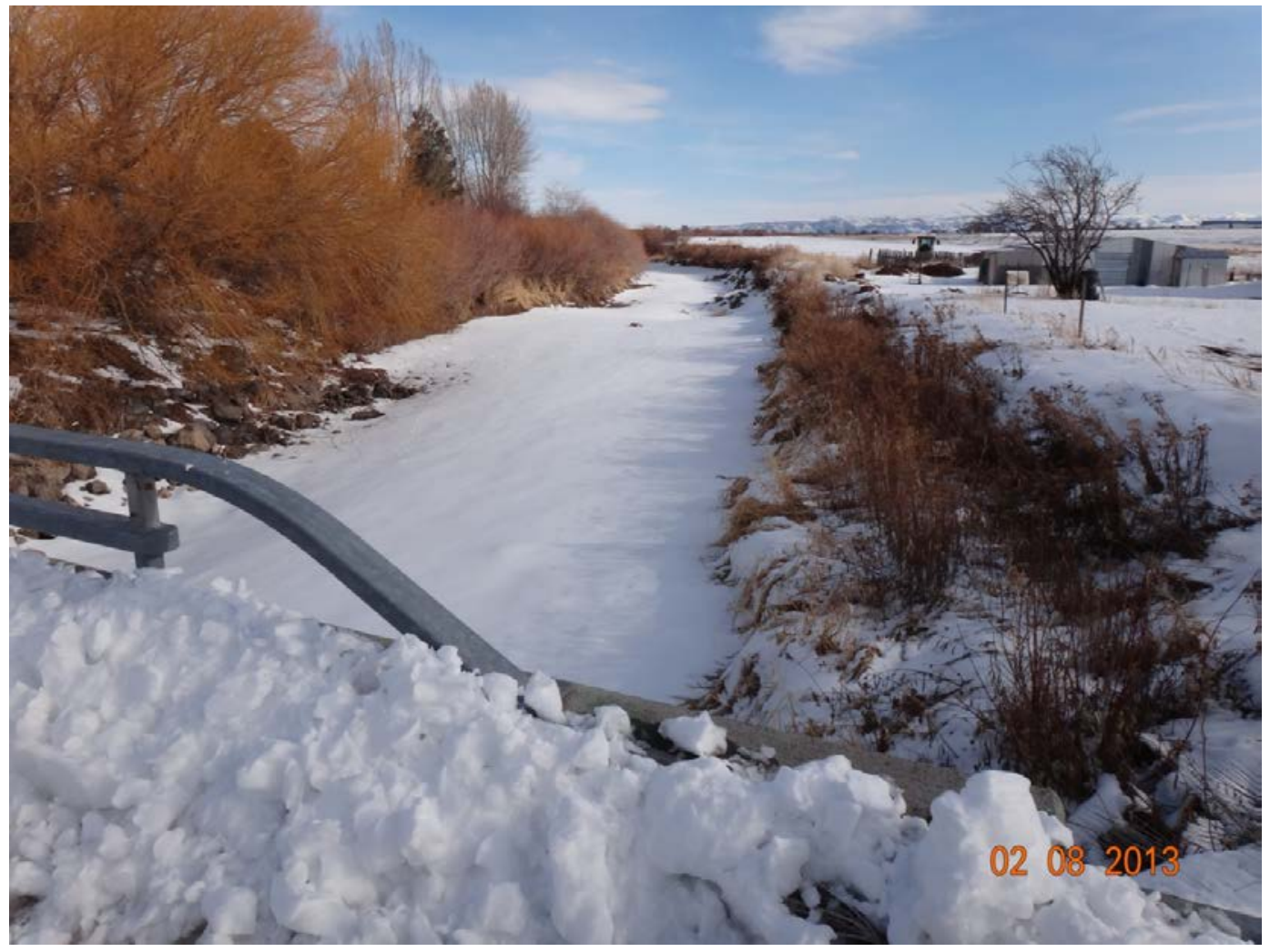

Figure 11. Looking upstream from the $95^{\text {th }}$ St. Bridge prior to release. 


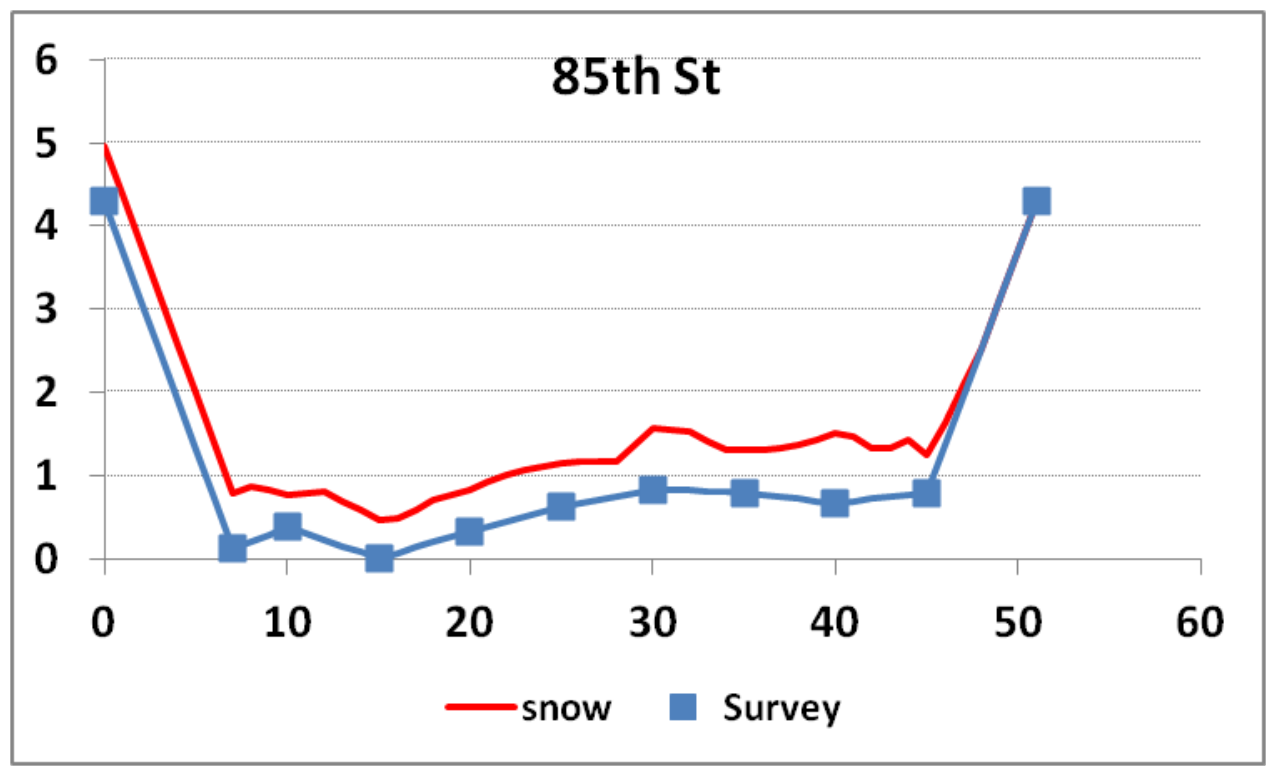

Figure 12. Snow depth and channel cross section (in feet) at the $85^{\text {th }}$ St. Bridge.

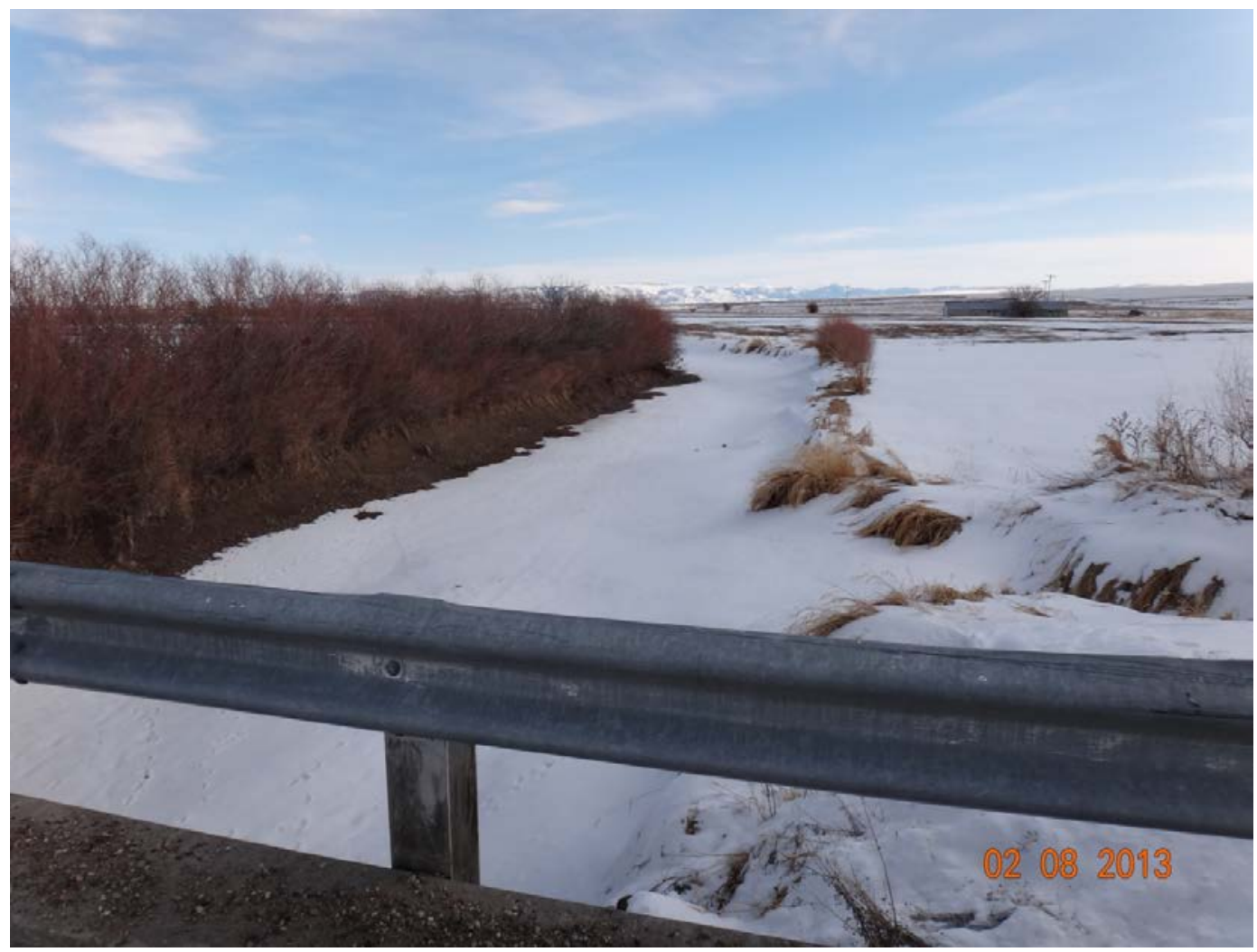

Figure 13. Looking upstream from the $85^{\text {th }}$ St. Bridge prior to release. 


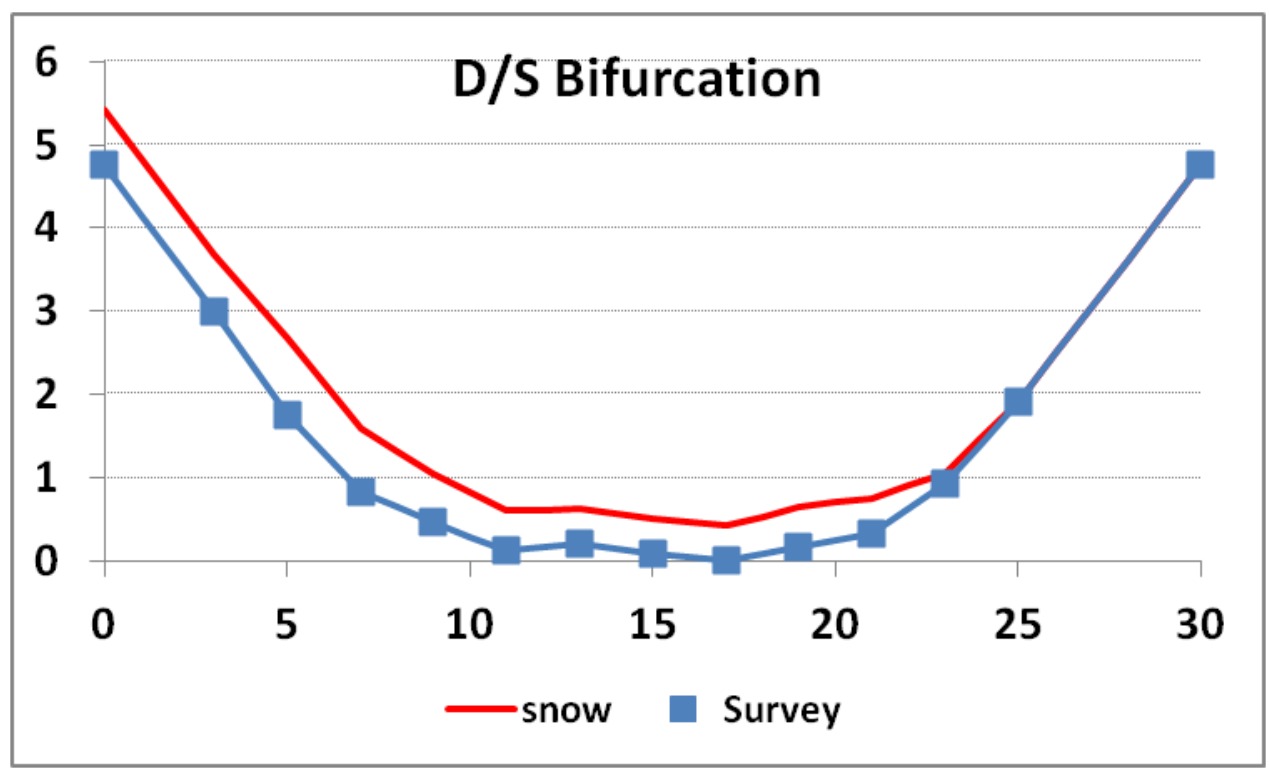

Figure 14. Snow depth and channel cross section (in feet) downstream of the Bifurcation.

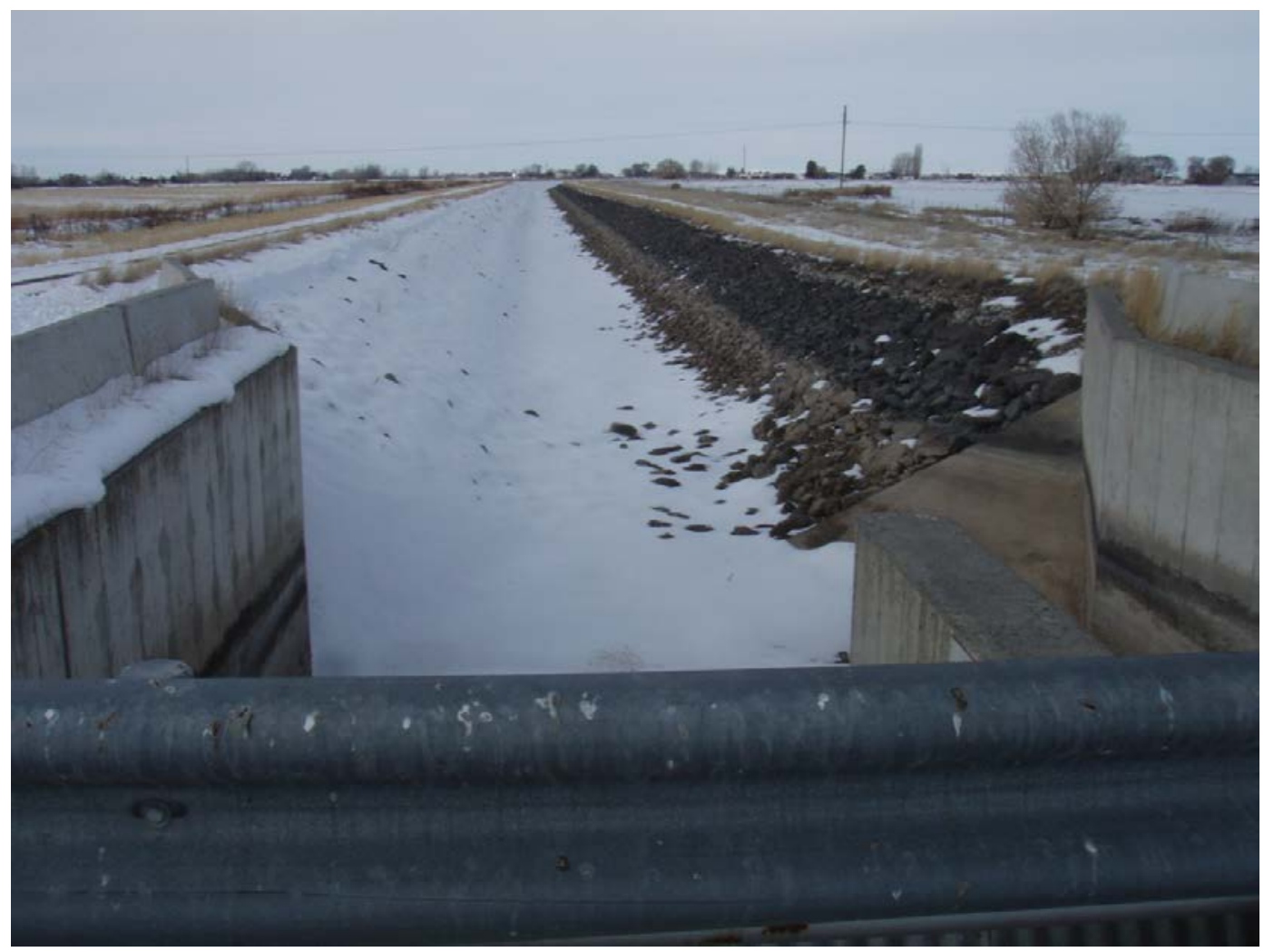

Figure 15. Looking downstream from the Bifurcation Control Structure prior to release. (Image by P. Cooper.) 


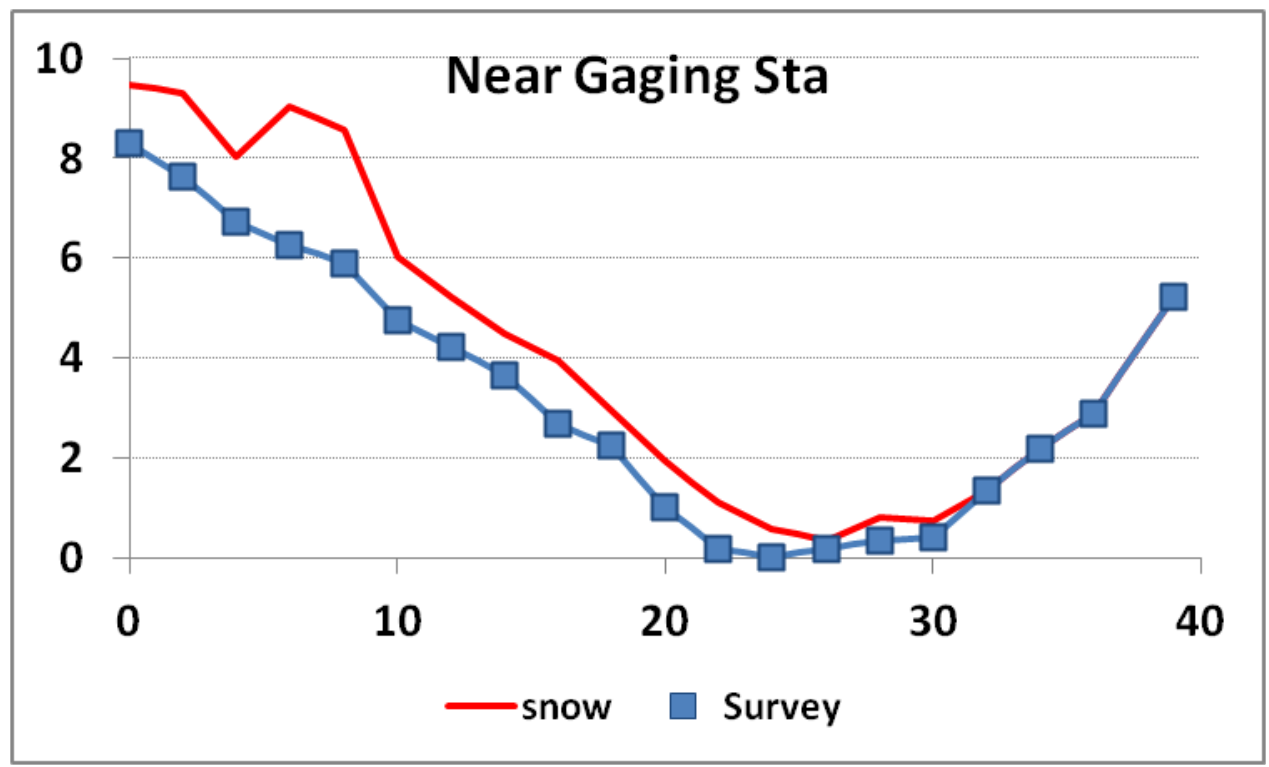

Figure 16. Snow depth and channel cross section (in feet) near the USGS Gaging Station.

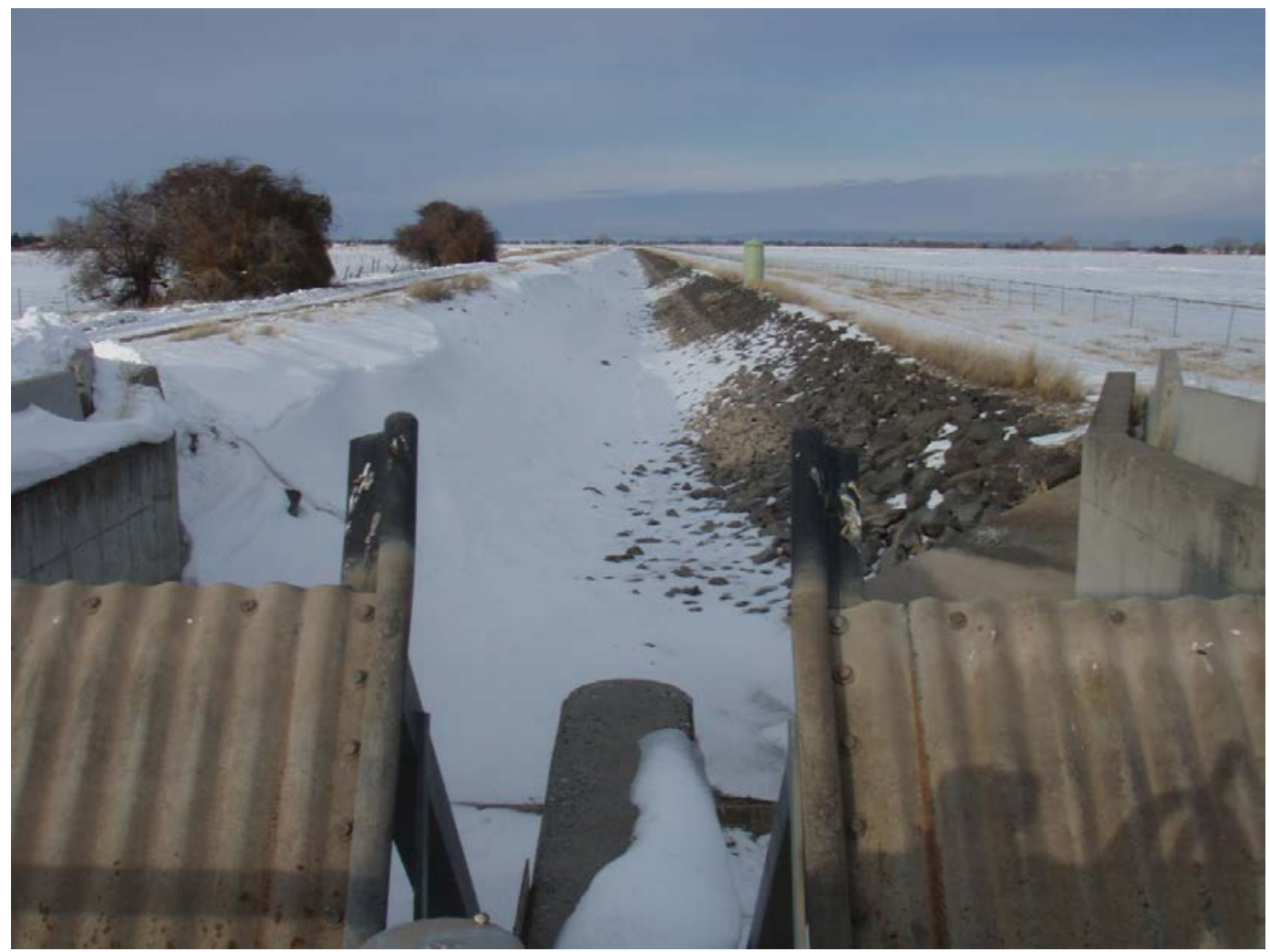

Figure 17. Looking downstream from the Willow Creek Head Gates prior to release. USGS gage is visible. (Image by P. Cooper.) 


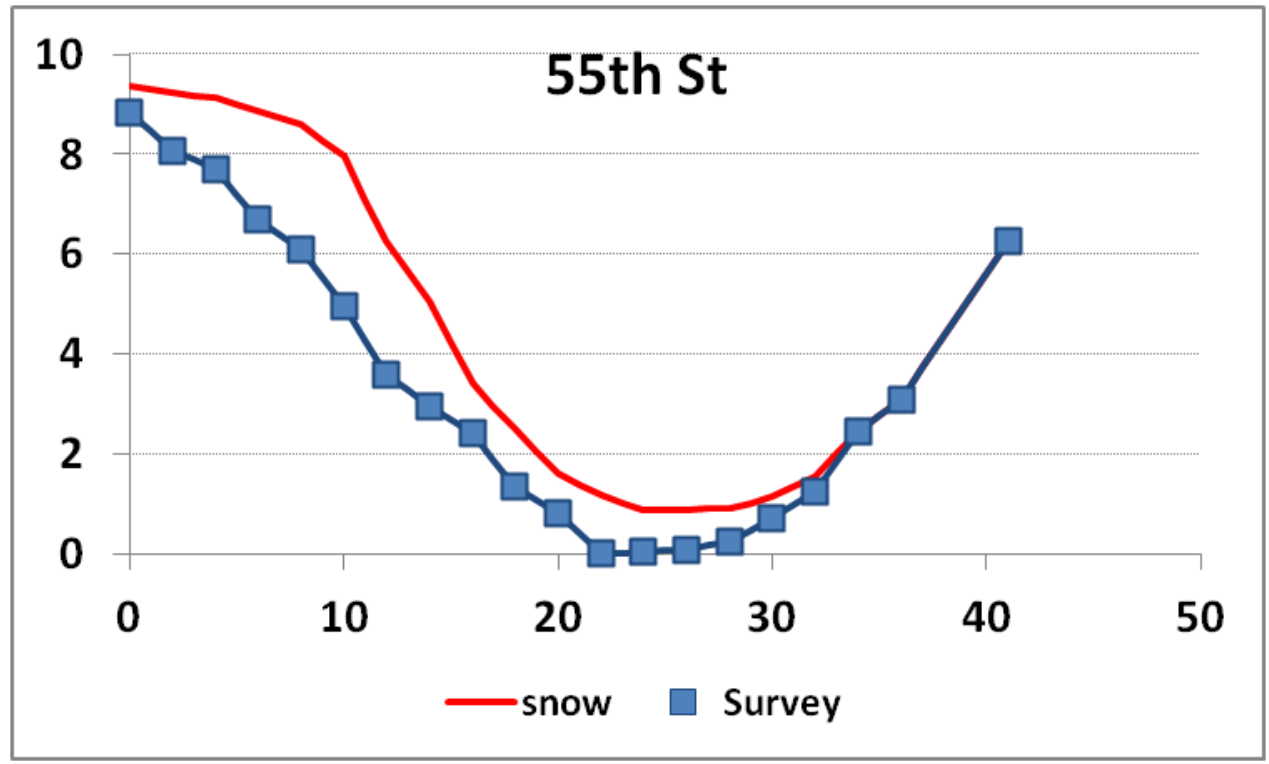

Figure 18. Snow depth and channel cross section (in feet) at the $55^{\text {th }}$ St. Bridge.

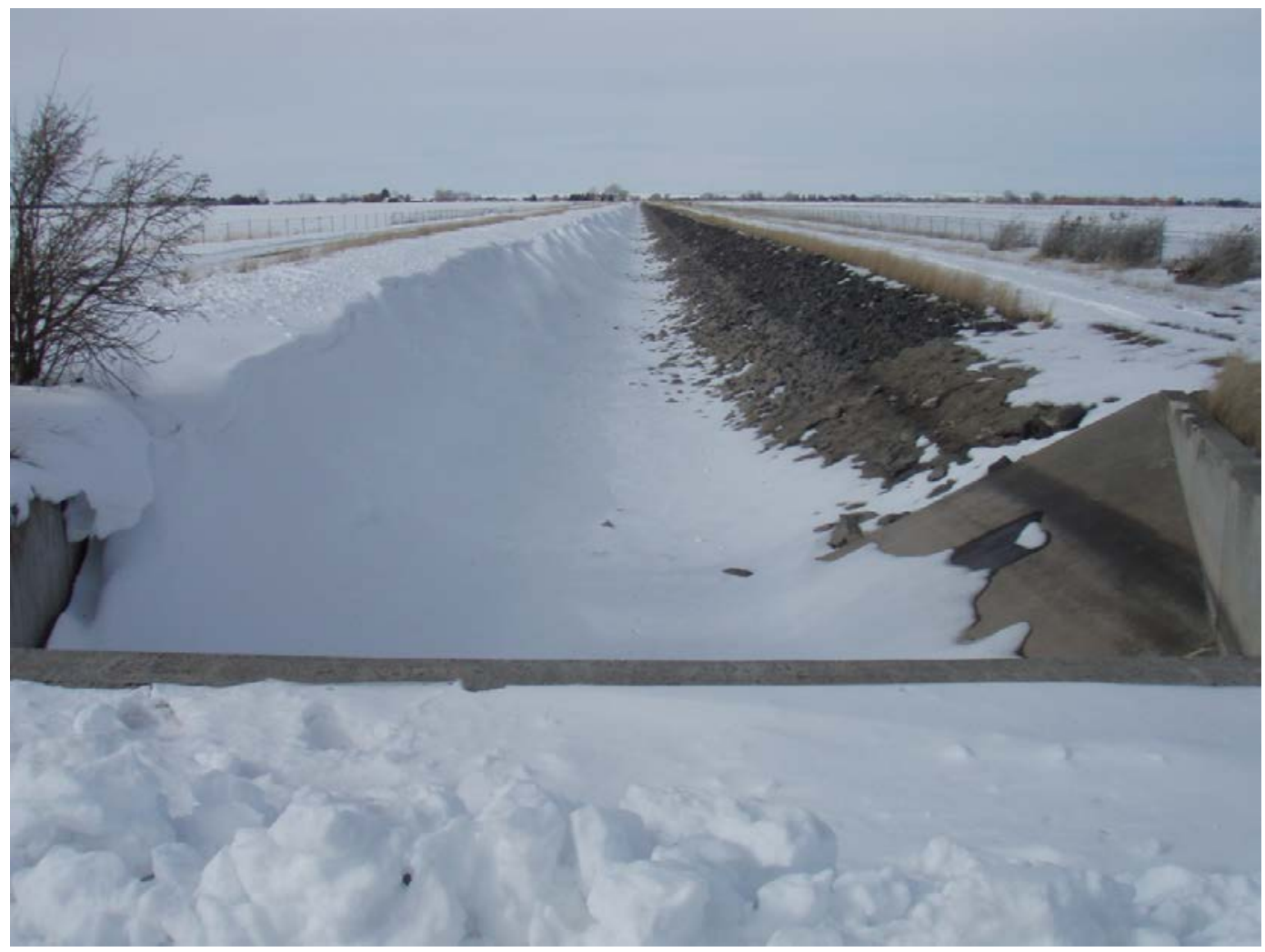

Figure 19. Looking downstream from the $55^{\text {th }}$ St. Bridge prior to release. (Image by P. Cooper.) 


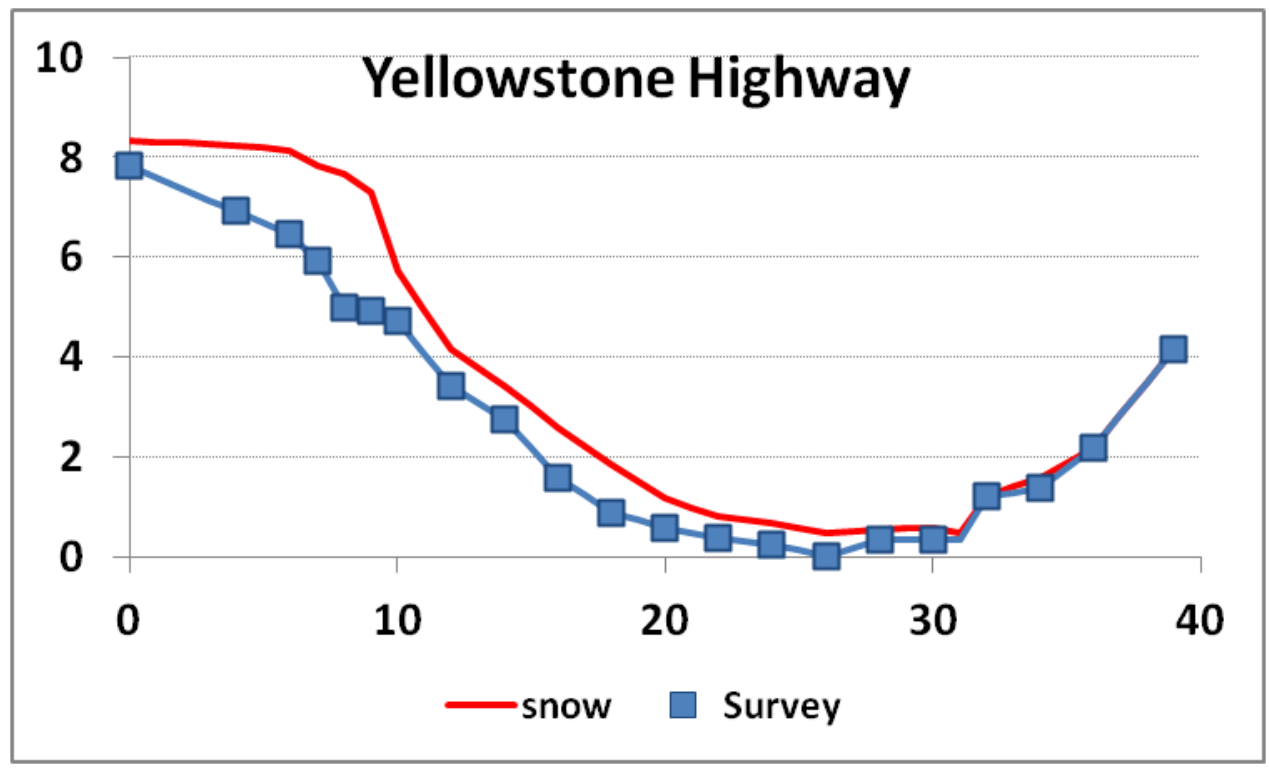

Figure 20. Snow depth and channel cross section (in feet) at the $35^{\text {th }}$ St. Bridge (Yellowstone Highway).

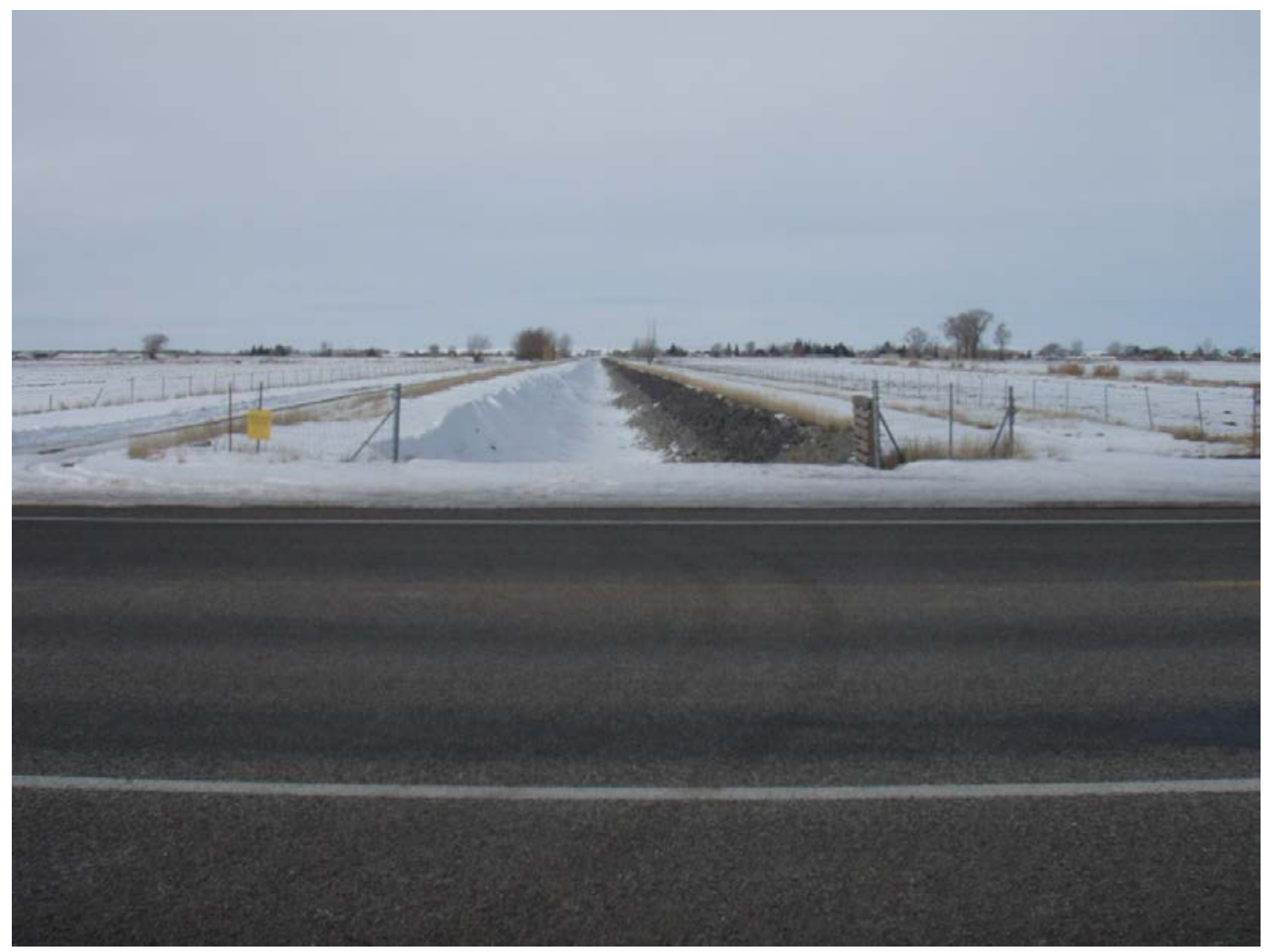

Figure 21. Looking downstream from the $35^{\text {th }}$ St. Bridge prior to release. (Image by P. Cooper.) 


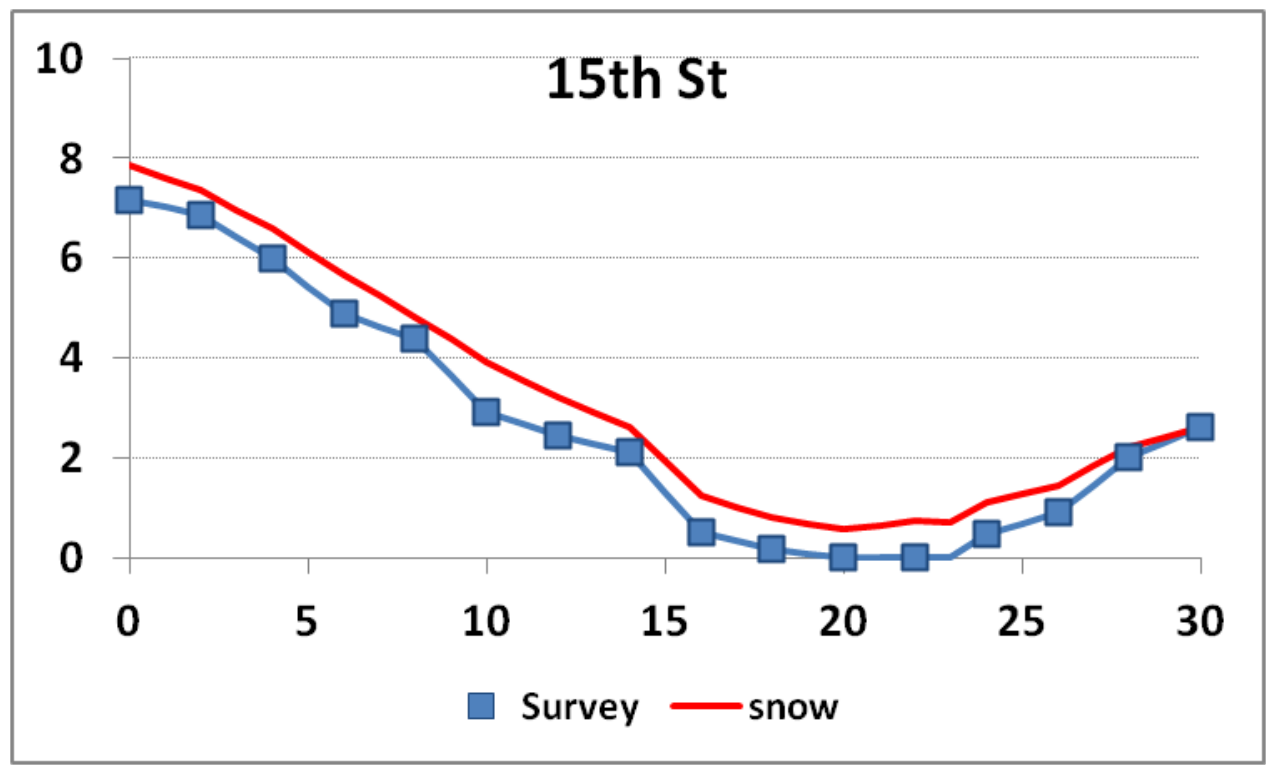

Figure 22. Snow depth and channel cross section (in feet) at the $15^{\text {th }}$ St. Bridge.

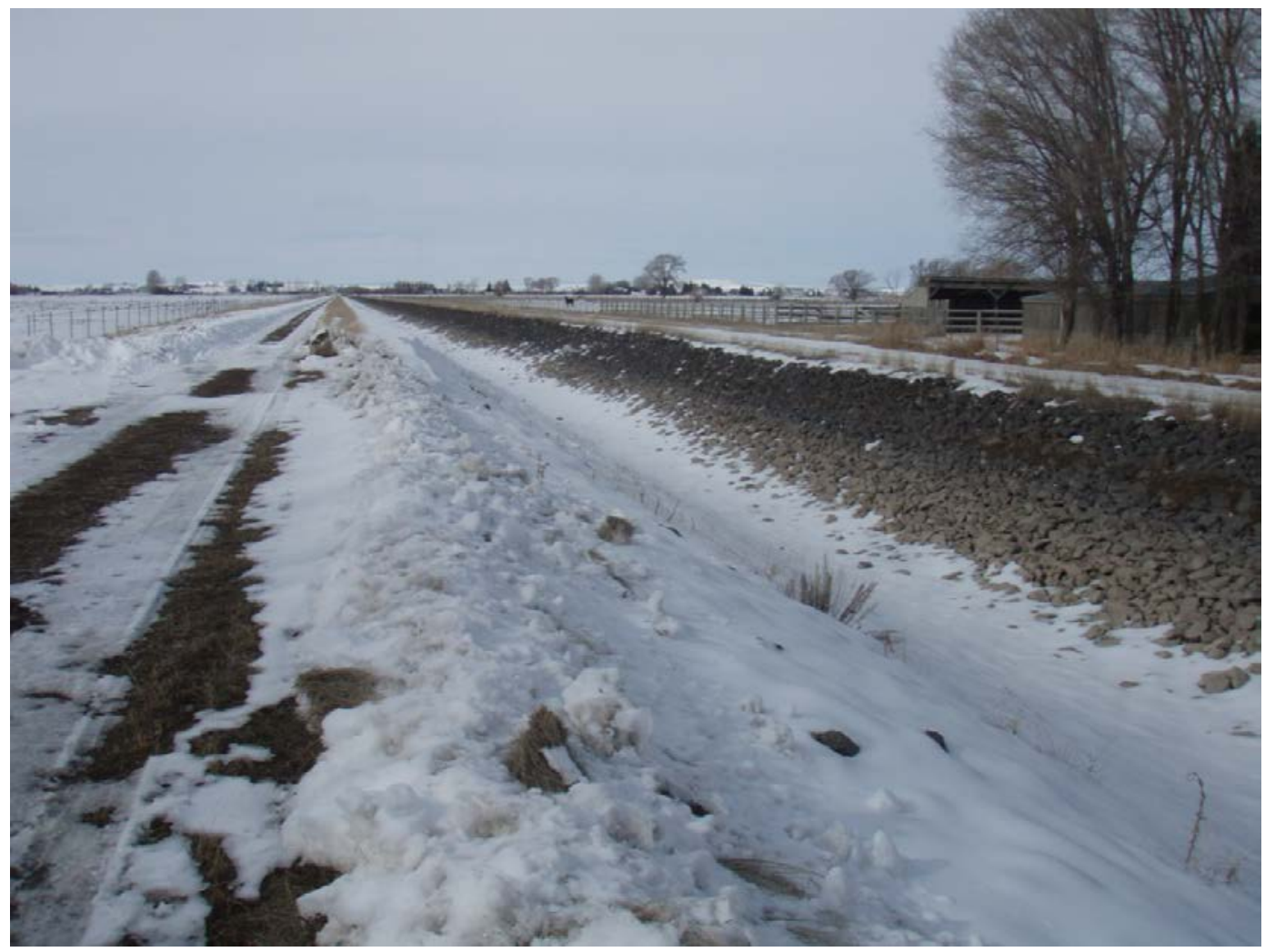

Figure 23. Looking downstream from the $15^{\text {th }}$ St. Bridge prior to release. (Image by P. Cooper.) 


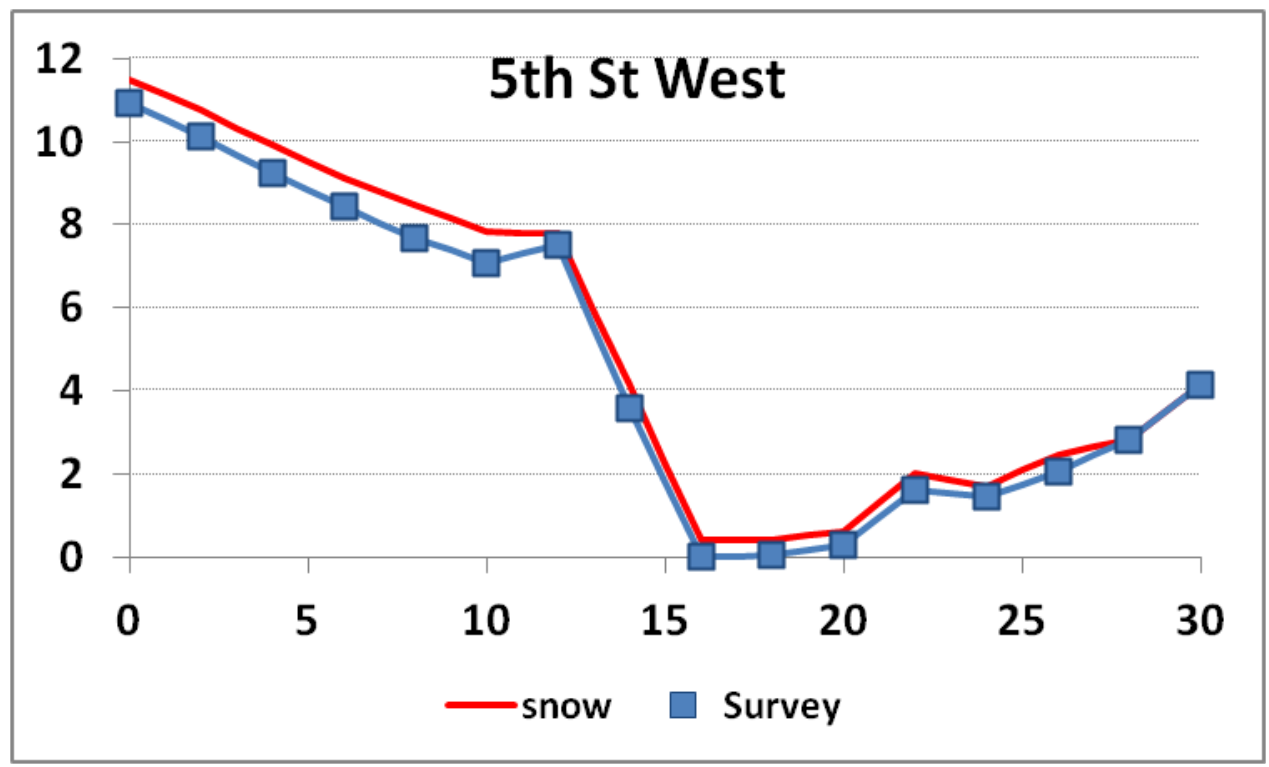

Figure 24. Snow depth and channel cross section (in feet) at the $5^{\text {th }}$ St. Bridge.

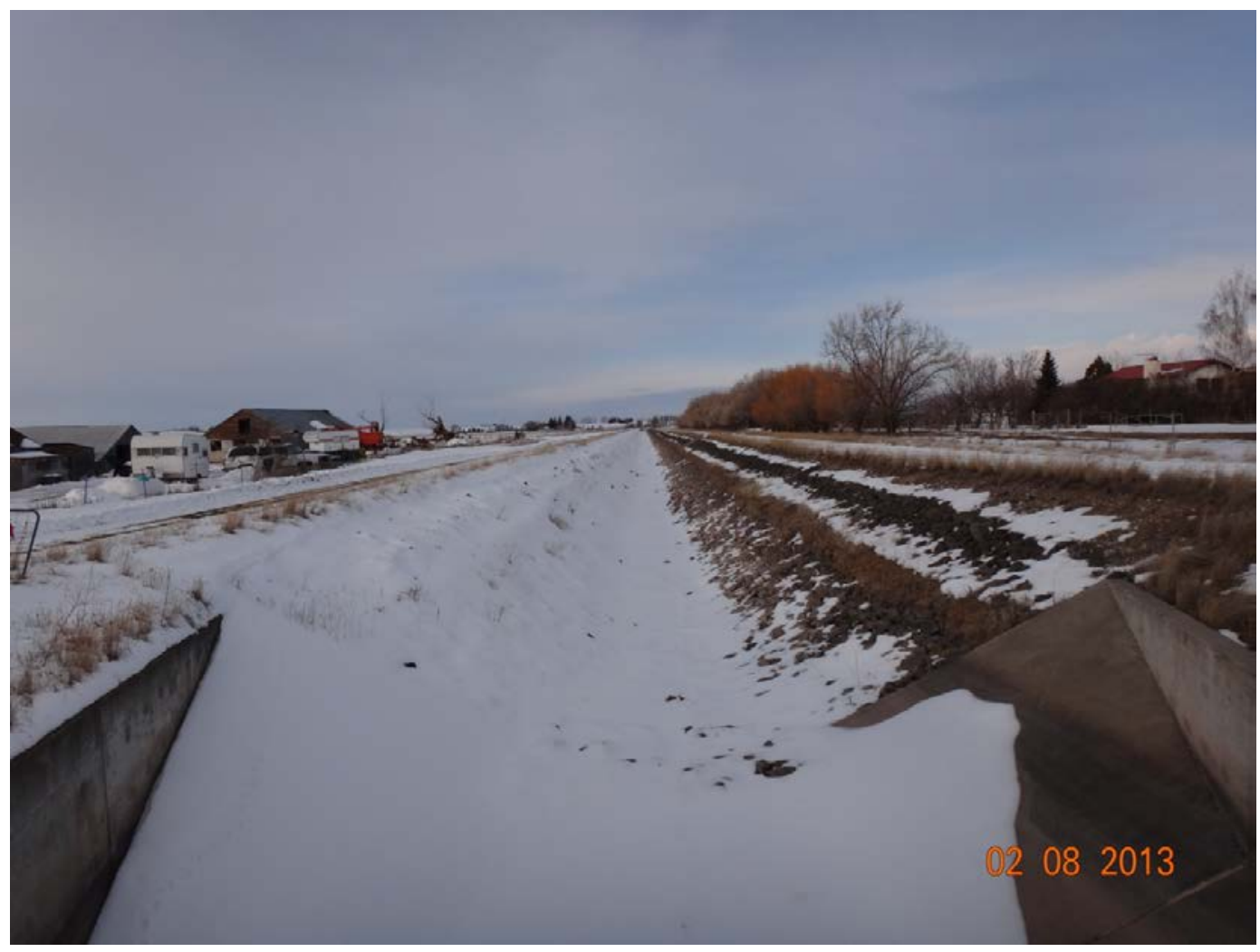

Figure 25. Looking downstream from the $5^{\text {th }}$ St. Bridge prior to release. 


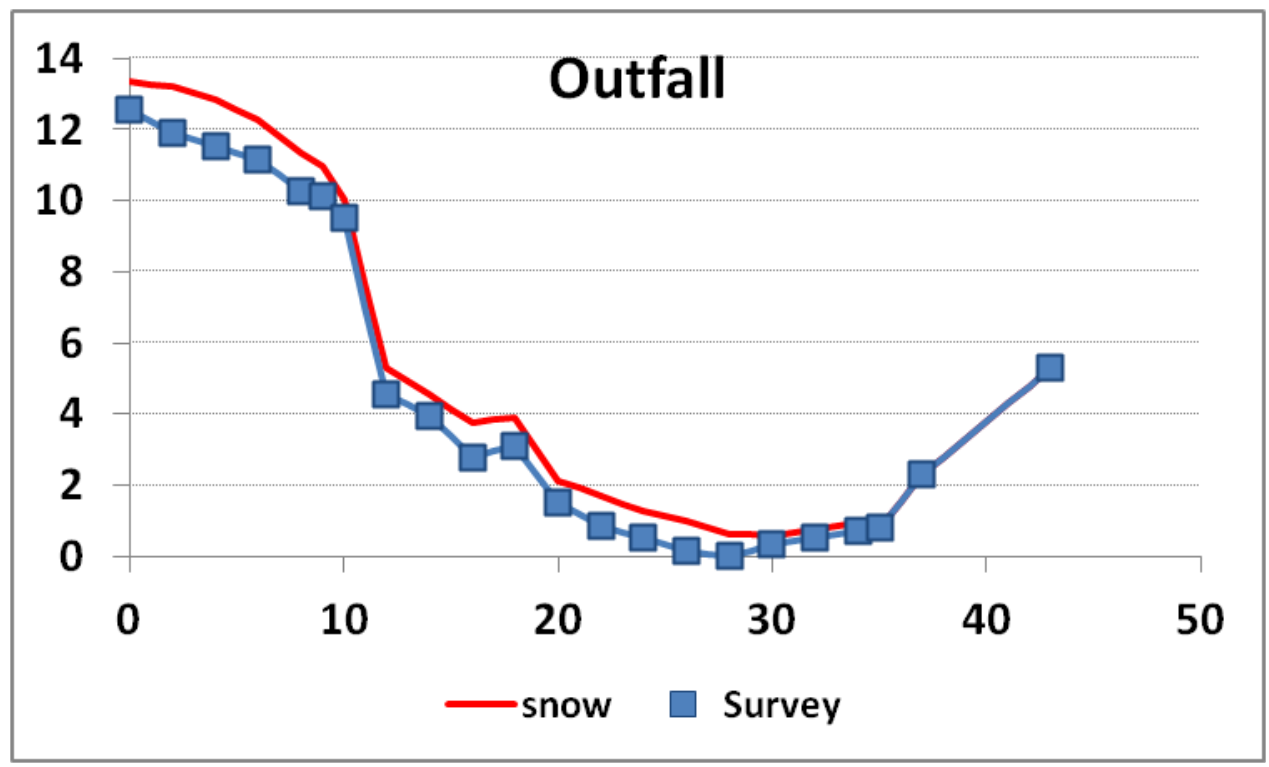

Figure 26. Snow depth and channel cross section (in feet) at the outfall.

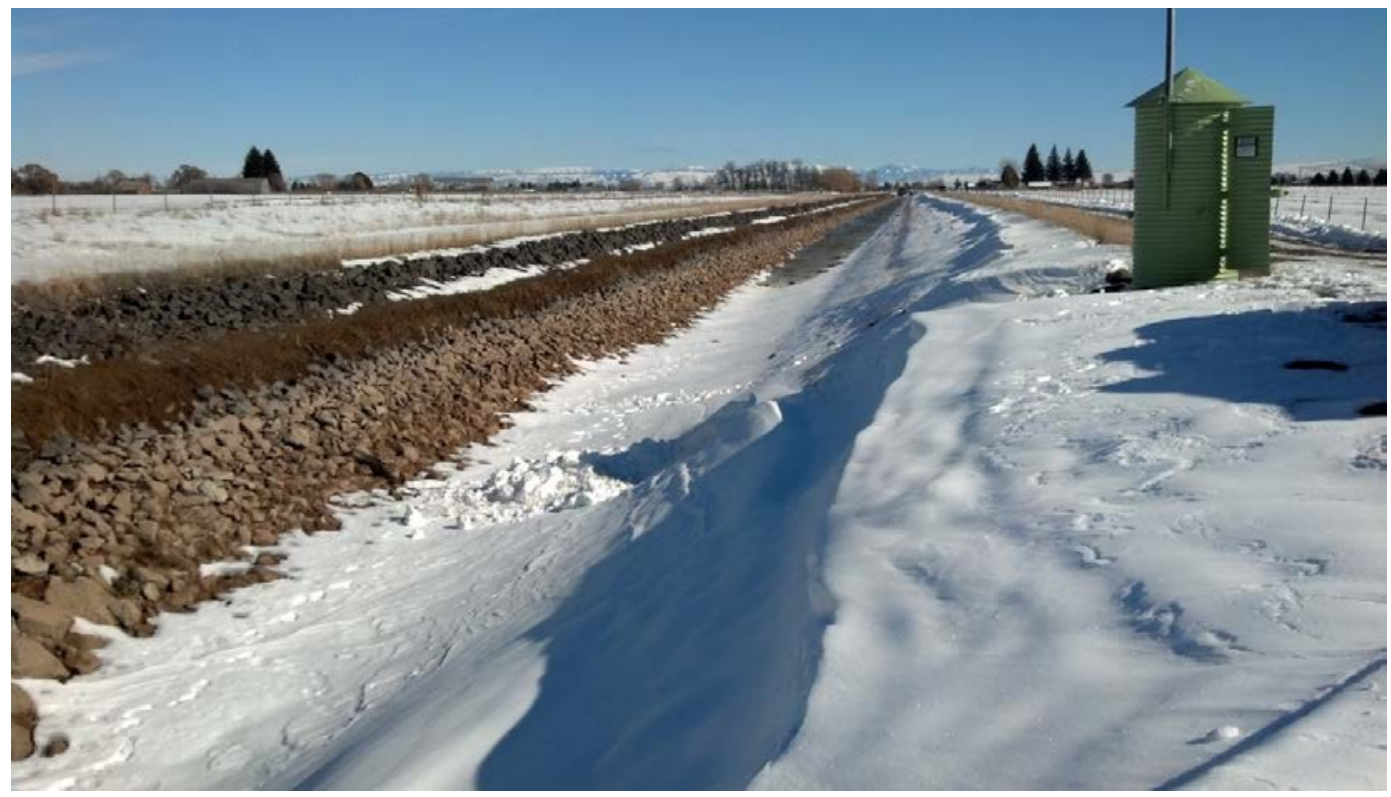

Figure 27. Looking upstream from the mouth of the Floodway Channel during release. 


\section{Release Test Observations}

Three USGS gages, 12 temporary water temperature recorders, and three temporary stage recorders installed by the Corps of Engineers made measurements of the flow conditions in Willow Creek during the Release Test; and personnel of the Corps and Idaho Department of Water Resources made visual observations. The Bureau of Reclamation made hourly air temperature measurements at Ririe Dam, and the National Weather Service (NWS) also made them hourly at the Idaho Falls Municipal Airport. This data collection program allowed the following to be determined:

- The propagation of the IRW from Ririe Dam along the dry channel to the mouth of the Willow Creek Outflow Channel at the Snake River.

- The propagation along Willow Creek of the changes in the outflow discharge from Ririe Dam.

- The timing, location, and extent of the dynamic ice cover development along the length of the Willow Creek.

- The melt-out of ice and snow in Willow Creek as the relatively warm water released by Ririe Dam was convected downstream.

This section describes the measurements and then discusses each of the above.

\subsection{Discharge}

There are three USGS gages in place on Willow Creek. Table 2 lists these gages and Figures 2 and 3 show their location. These are permanent gage locations in place for many years. The gages recorded stage at all three locations and water temperature at two locations every 15 min throughout the Release Test.

The USGS estimated the discharge at their sites using rating curves developed from previous flow and stage measurements. The extent to which the ice and snow in the channel affected the accuracy of the discharge estimates during the Release Test is not known.

Figure 28 shows the discharge estimates, and the gage at the outlet of Ririe Dam (USGS Gage 13058000) shows clearly the three discharge steps of 150 cfs, 300 cfs, and 500 cfs. The two downstream gages (USGS Gages 
13058520 and 13058529) show clearly the arrival of the IRW. A period of transient flow in which the apparent discharge at the two downstream gages varied above and below the $150 \mathrm{cfs}$ outflow rate followed the arrival of the Initial Release Wave. The increase to $300 \mathrm{cfs}$ followed before this transient settled out, and the start of the period of the $300 \mathrm{cfs}$ flow was not clearly visible at the two downstream gages. Both downstream gages reached a period of near steady flow after the wave of the 500 cfs release reached their location. Tables 4 and 5 list the arrival times of the IRW, the 300 cfs flow, and the 500 cfs flow at each of the USGS gages. They list separately the leading edge of each increase, when the discharge was observed to increase, and the actual time when the outlet flow was reached.

It is interesting to note that the final steady flow during this period averaged 464 cfs at the mouth of the Willow Creek Outflow Channel (USGS Gage 13058520) and 480 cfs at the upstream gage near the Willow Creek headworks (USGS Gage 13058529). This suggests that some flow in the Willow Creek channel was lost to groundwater recharge, leakage through control gates, or other causes during the Release Test.

Table 2. USGS gages.

\begin{tabular}{|l|l|l|l|l|l|}
\hline $\begin{array}{l}\text { Distance from } \\
\text { Mouth (ft) }\end{array}$ & $\begin{array}{l}\text { Gage } \\
\text { Number }\end{array}$ & Gage Name & Approximate Location & Data & $\begin{array}{l}\text { Start } \\
\text { Year }\end{array}$ \\
\hline 120,000 & 13058000 & WILLOW CREEK NR RIRIE ID & 0.25 miles below Ririe Dam & Temp., Flow & 1903 \\
\hline 36,000 & 13058520 & $\begin{array}{l}\text { WILLOW CREEK FLOODWAY } \\
\text { CHANNEL NR UCON ID }\end{array}$ & $\begin{array}{l}300 \mathrm{ft} \text { below Willow Creek } \\
\text { channel diversion structure }\end{array}$ & Flow & 1978 \\
\hline 80 & 13058529 & $\begin{array}{l}\text { WILLOW CR FLOODWAY } \\
\text { CHANNEL AT MOUTH NR ID } \\
\text { FALLS ID }\end{array}$ & $\begin{array}{l}80 \mathrm{ft} \text { upstream (u/s) of } \\
\text { mouth }\end{array}$ & Temp., Flow & 1987 \\
\hline
\end{tabular}




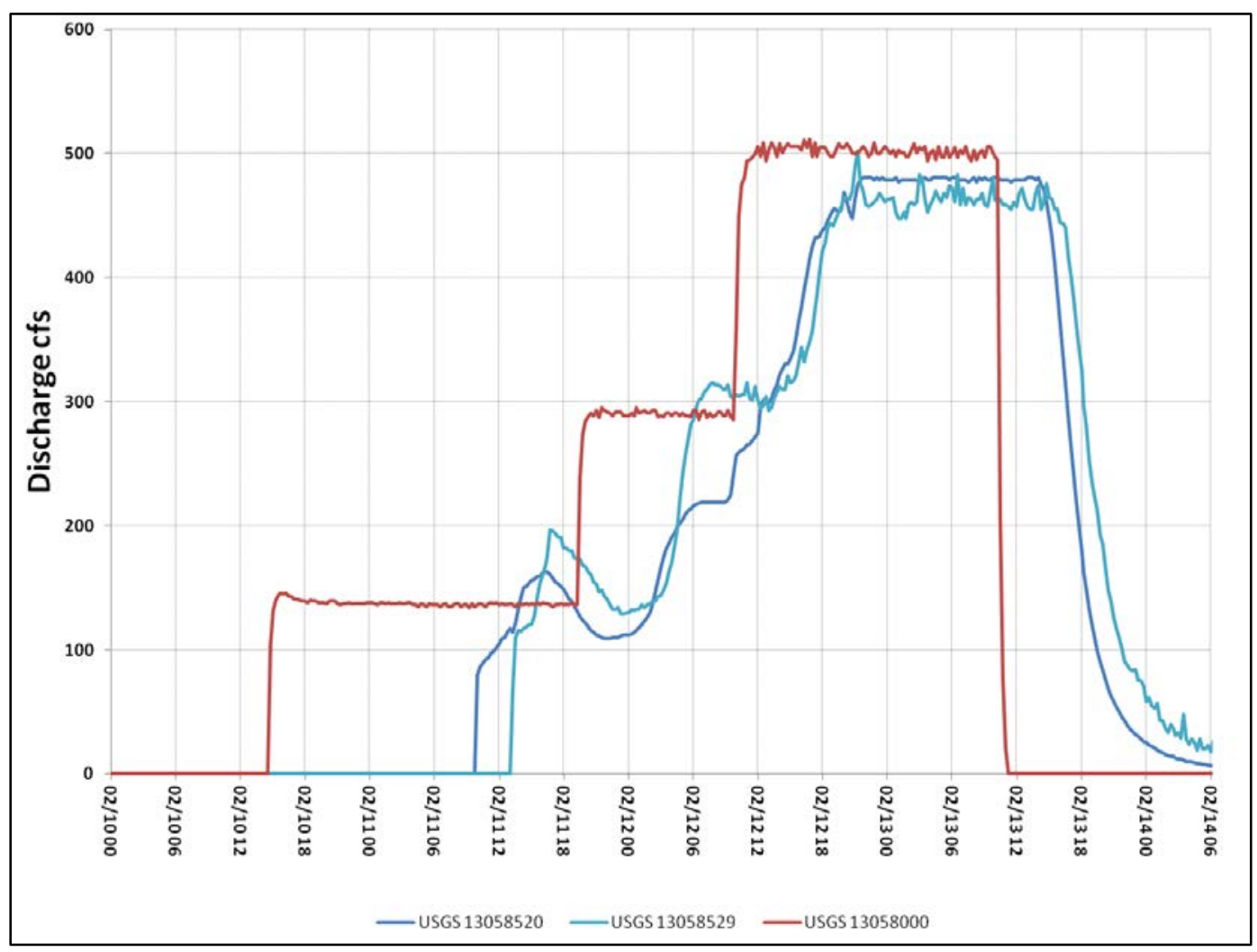

Figure 28. Observed discharge at the USGS gages during the Release Test.

\subsection{Water temperature}

The USGS made water temperature measurements at two of their gages (USGS Gages 13058000 and 13058529). Water temperature measurements were also made at six other locations using temporary water temperature sensors installed by the Corps (Table 3). The Corps installed two temperature sensors at the six locations providing a total of twelve time series of temperature. Each of these locations was immediately downstream of the bridge crossing listed in Table 3. The USGS data were recorded at 15-min intervals and the Corps data at 10-min intervals. In addition, at three locations, the Corps installed pressure sensors for stage measurement that also recorded water temperature (Table 3). These sensors recorded data every $30 \mathrm{~s}$. In total, there were 17 time series of water temperature data recorded at seven different locations along Willow Creek. In every case, there was very little difference between the water temperature measurements made by different sensors at any one location.

The water temperature sensors installed at the outlet of Ririe Dam were underwater during the entire Release Test and recorded the outlet water temperature as shown in Figure 29. The outlet temperature held very 
steady with only a slight decline from $3.8^{\circ} \mathrm{C}\left(38.8^{\circ} \mathrm{F}\right)$ to $3.5^{\circ} \mathrm{C}\left(38.3^{\circ} \mathrm{F}\right)$ over the course of the Release Test. The remaining temperature sensors were exposed to the air and recorded the air temperature prior to the arrival of the IRW. The air temperatures were relatively low in the hours leading up to the arrival of the IRW, with air temperatures dropping down to $-15^{\circ} \mathrm{C}\left(5^{\circ} \mathrm{F}\right)$. The temperature sensors detected the arrival of the IRW at a specific location when the water temperature jumped abruptly to $0^{\circ} \mathrm{C}$ $\left(32^{\circ} \mathrm{F}\right)$. Figure 29 clearly shows these jumps, and Table 3 lists the data and time of the IRW. After the arrival of the IRW, the water temperature remained at a constant value of $0^{\circ} \mathrm{C}\left(32^{\circ} \mathrm{F}\right)$ for a period. During this time, both ice and liquid water existed in the channel. Once the ice in the channel upstream of a specific location had effectively melted, the water temperature could rise towards the temperature of the water released from Ririe Dam. The actual temperature recorded at any site after the ice had melted resulted from the balance between the heat input from Ririe Dam and the heat loss/gain through the water surface to the atmosphere. As the air temperatures were generally below $0^{\circ} \mathrm{C}\left(32^{\circ} \mathrm{F}\right)$ for almost all of the $\mathrm{Re}$ lease Test, there was a heat loss from the water surface. This is also indicated by the slightly lower temperatures at each successive site moving downstream.

Table 3. Corps of Engineers water temperature data summary.

\begin{tabular}{|c|c|c|c|}
\hline \multicolumn{4}{|c|}{ HOBO Water Temperature Pro v2 Data Logger-U22-001 } \\
\hline Serial Number & Location & Release Wave Arrival & Above $0^{\circ} \mathrm{C}$ \\
\hline 10120108 & Ririe outfall (2) & \multirow[t]{2}{*}{$2 / 10 / 2013$ at 1440} & \multirow[t]{2}{*}{$2 / 10 / 2013$ at 1440} \\
\hline 9937334 & Ririe outfall (1) & & \\
\hline 9937335 & 95th St. (2) & \multirow[t]{2}{*}{$2 / 11 / 2013$ at 0330} & \multirow[t]{2}{*}{$2 / 12 / 2013$ at 1410} \\
\hline 10120114 & 95th St. (1) & & \\
\hline 10120115 & $55^{\text {th }}$ St. (2) & \multirow[t]{2}{*}{$2 / 11 / 2013$ at 1010} & \multirow[t]{2}{*}{$2 / 12 / 2013$ at 2120} \\
\hline 10120111 & $55^{\text {th }}$ St. (1) & & \\
\hline 9737377 & $35^{\text {th }}$ St. (2) & \multirow[t]{2}{*}{$2 / 11 / 2013$ at 1110} & \multirow[t]{2}{*}{$2 / 12 / 2013$ at 2240} \\
\hline 10120119 & 35th St. (1) & & \\
\hline 9937331 & $15^{\text {th }}$ St. (2) & \multirow[t]{2}{*}{$2 / 11 / 2013$ at 1200} & \multirow[t]{2}{*}{$2 / 12 / 2013$ at 2350} \\
\hline 10120116 & $15^{\text {th }}$ St. (2) & & \\
\hline 10120112 & $5^{\text {th }}$ St. West (2) & & \multirow[t]{2}{*}{$2 / 13 / 2013$ at 0130} \\
\hline 10120113 & $5^{\text {th }}$ St. West (1) & & \\
\hline \multicolumn{4}{|c|}{ HOBO Pressure Sensors that also recorded water temperature } \\
\hline Serial Number & Location & Release Wave Arrival & Above $0^{\circ} \mathrm{C}$ \\
\hline 2414446 & $55^{\text {th }}$ St. & $2 / 11 / 2013$ & $2 / 12 / 2013$ at 2120 \\
\hline 2414447 & $35^{\text {th }}$ St. & $2 / 11 / 2013$ & $2 / 12 / 2013$ at 2231 \\
\hline 2428956 & $15^{\text {th }}$ St. & $2 / 11 / 2013$ & $2 / 12 / 2013$ at 2355 \\
\hline
\end{tabular}




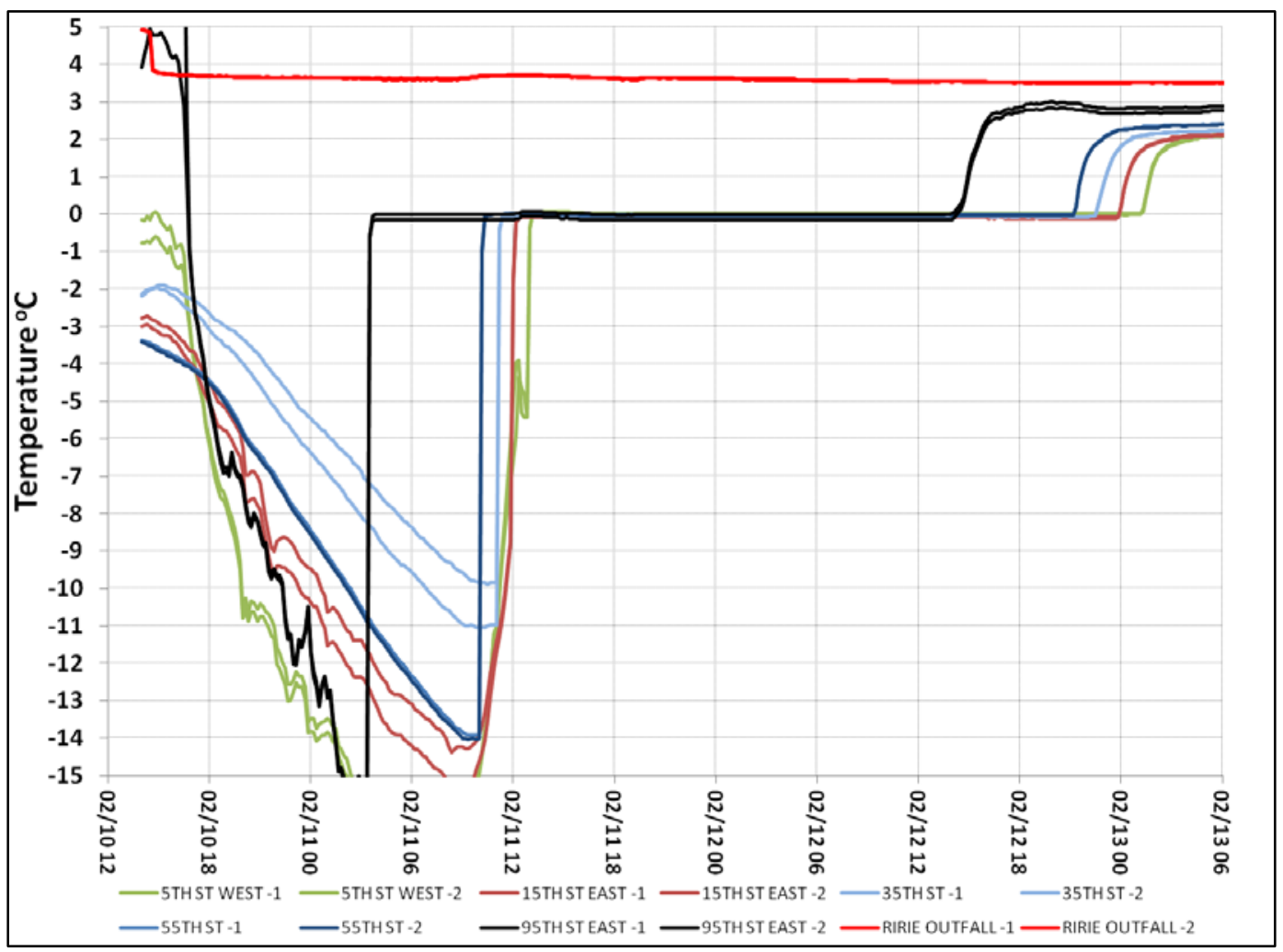

Figure 29. Observed water temperatures.

\subsection{Air temperature}

The Bureau of Reclamation made hourly air temperature measurements at the Ririe Dam, and the NWS made hourly measurements at the Idaho Falls Municipal Airport. Figure 30 shows the air temperature record over the course of the Release Test. The coldest air temperatures were recorded around 0700 on 11 February when the air temperature ranged between $5^{\circ} \mathrm{F}\left(-15^{\circ} \mathrm{C}\right)$ and $0^{\circ} \mathrm{F}\left(-17.8^{\circ} \mathrm{C}\right)$. Over the course of the Release Test, the air temperatures remained below $0^{\circ} \mathrm{C}\left(32^{\circ} \mathrm{F}\right)$ but were fairly moderate. 


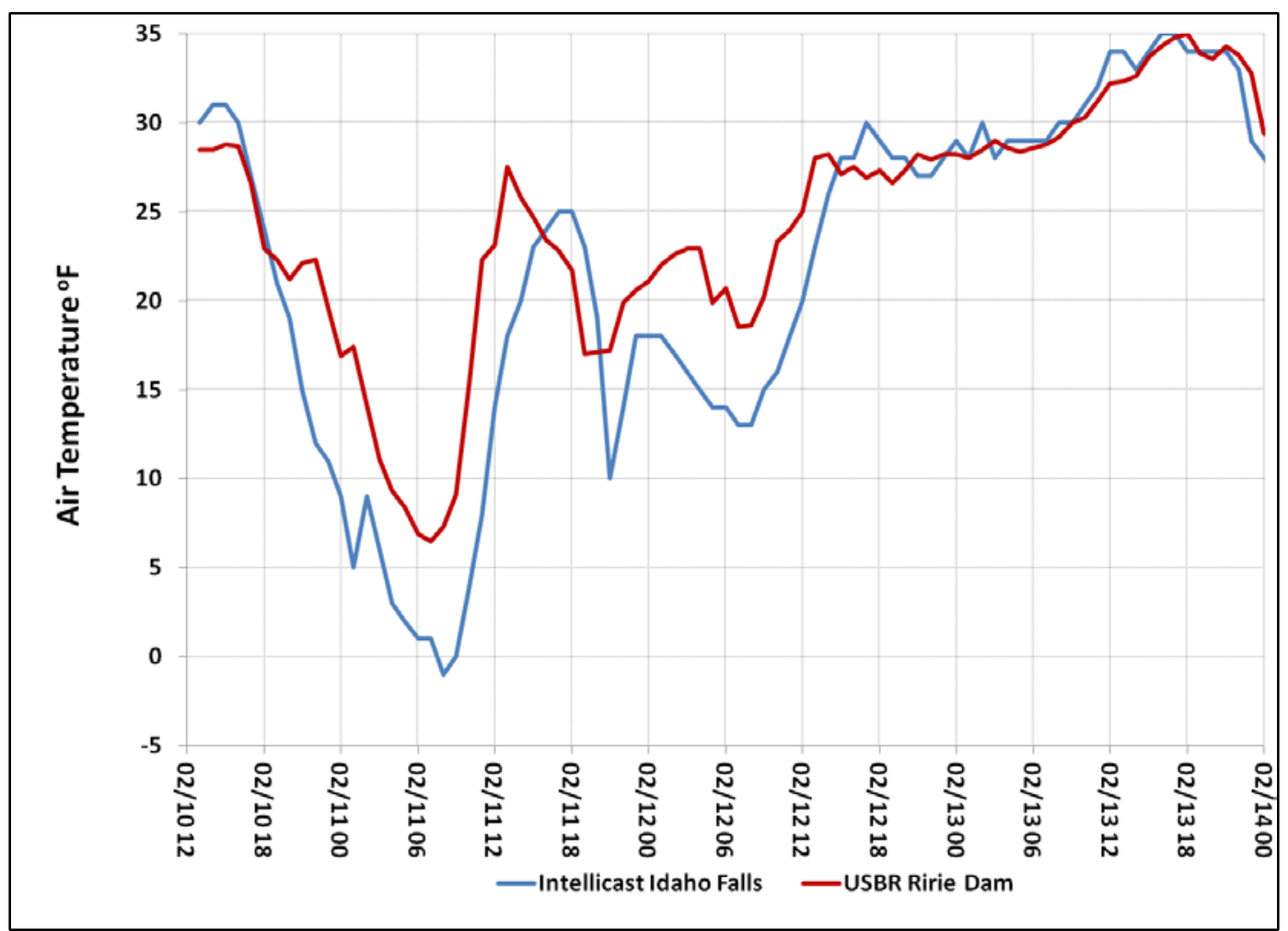

Figure 30. Observed air temperature.

\subsection{Stage}

Three temporary pressure gages installed by the Corps made stage measurements at the USGS gages. The Corps installed gages at the locations listed in Table 3. Figure 31 shows the measured stages. The stages at the USGS gages are shown relative to the stage immediately before the arrival of the IRW and not relative to the gage datum. The stage at the USGS gage immediately downstream of Ririe Dam is not shown. One can clearly see the arrival of the IRW at each of the locations and the transient flow that followed. Unfortunately, as Figure 31 shows, two of the Corps gages (labeled probes) apparently moved during the course of the Release Test. These gages probably provided an accurate measurement of the water stage prior to the time that the gages moved. 


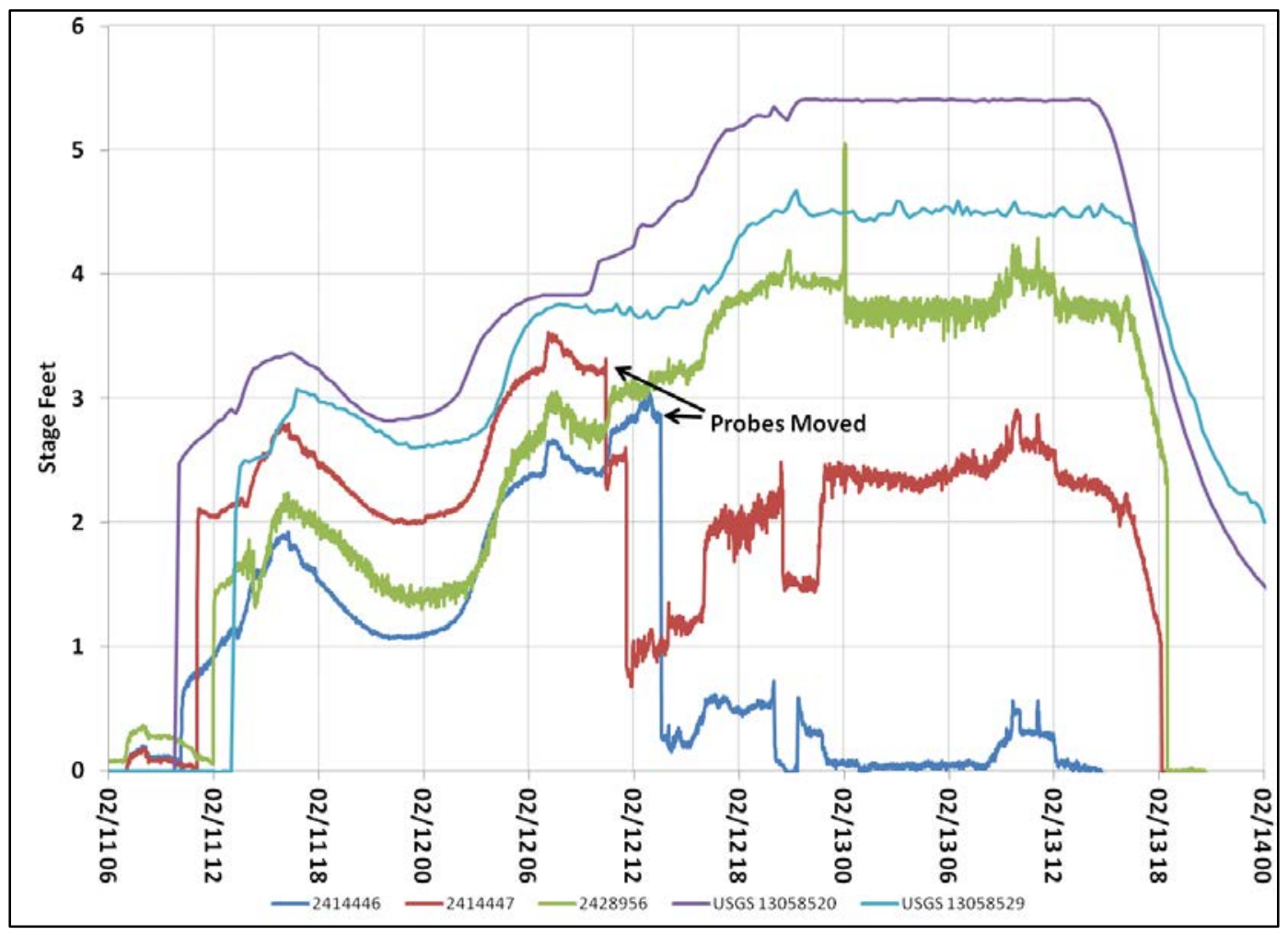

Figure 31. Observed stages.

\subsection{Willow Creek hydraulic conditions}

\subsubsection{Initial Release Wave propagation}

The IRW began at approximately 1420 on 10 February 2013 when the $\mathrm{Bu}$ reau of Reclamation opened the gates of Ririe Dam to allow a flow of 150 cfs to pass. This release wave propagated downstream and arrived at the Snake River at 1315 on 11 February 2013, for a travel time of $22 \mathrm{hr}$ and 55 $\mathrm{min}$. The propagation of the IRW was tracked in three ways: by noting the arrival time at the USGS gages, by the abrupt change of temperature at the Corps water temperature sensors, and by on-site personnel's observations. Table 4 and Figure 32 show the IRW propagation results. The IRW traveled at an overall average velocity of $1.45 \mathrm{fps}$. It moved faster in the Floodway Channel than in the natural channel sections upstream. At every section observed, the snow in the channel remained in place during and after the IRW traveled through each section. The IRW did not significantly remove, dislodge, or erode away the snow that was in place prior to the $\mathrm{Re}$ lease Test. This required the IRW to travel on top of the snow and around any snow drifts in place and indicates that only part of the channel area was available for conveyance. 
Table 4. Summary of the Initial Release Wave propagation. (Average velocity is the average propagation speed from Ririe Dam to that point.)

\begin{tabular}{|c|c|c|c|c|c|c|}
\hline $\begin{array}{l}\text { Distance } \\
\text { (ft) }\end{array}$ & Location & $\begin{array}{l}\text { Observation } \\
\text { Type }\end{array}$ & $\begin{array}{c}\text { Arrival } \\
\text { Date Time }\end{array}$ & $\begin{array}{l}\text { Total Travel } \\
\text { Time }\end{array}$ & $\begin{array}{c}\text { Average } \\
\text { Velocity } \\
\text { (fps) }\end{array}$ & $\begin{array}{c}\text { Velocity } \\
\text { (between } \\
\text { sites) }\end{array}$ \\
\hline 119,880 & Ririe Dam & Temp, Stage & $2 / 10 / 2013$ at 1420 & $0 \mathrm{hr}$ & & \\
\hline 84,480 & $115^{\text {th }}$ St. Bridge & & & & & \\
\hline 74,700 & Ferguson Bridge & On-site obs. & $2 / 11 / 2013$ at 0030 & $10 \mathrm{hr} 10 \mathrm{~min}$ & 1.23 & 1.23 \\
\hline 64,700 & N 95 th $E$ & Temp & $2 / 11 / 2013$ at 0330 & $13 \mathrm{hr} 10 \mathrm{~min}$ & 1.16 & 0.93 \\
\hline 47,500 & $N 85^{\text {th }} E$ & & & & & \\
\hline 40,900 & Bifurcation & On-site obs. & $2 / 11 / 2013$ at 0910 & $18 \mathrm{hr} 50 \mathrm{~min}$ & 1.16 & 1.17 \\
\hline 37,700 & $\begin{array}{l}26^{\text {th }} \text { St. Highway } \\
\text { Bridge }\end{array}$ & On-site obs. & $2 / 11 / 2013$ at 0935 & 19 hr 15 min & 1.19 & 2.13 \\
\hline 36,000 & USGS gage & Stage & $2 / 11 / 2013$ at 1000 & 19 hr 42 min & 1.18 & 1.13 \\
\hline 33,020 & 55th St. Bridge & $\begin{array}{l}\text { On-site obs., } \\
\text { Temp }\end{array}$ & $2 / 11 / 2013$ at 1002 & $19 \mathrm{hr} 44 \mathrm{~min}$ & 1.22 & 2.89 \\
\hline 27,780 & $45^{\text {th }}$ St. Bridge & On-site obs. & $2 / 11 / 2013$ at 1033 & $20 \mathrm{hr} 13 \mathrm{~min}$ & 1.27 & 2.82 \\
\hline 22,430 & Highway 42 Bridge & $\begin{array}{l}\text { On-site obs., } \\
\text { Temp }\end{array}$ & $2 / 11 / 2013$ at 1103 & $20 \mathrm{hr} 43 \mathrm{~min}$ & 1.31 & 2.97 \\
\hline 17,010 & $25^{\text {th }}$ St. Bridge & On-site obs. & $2 / 11 / 2013$ at 1125 & $21 \mathrm{hr} 5 \mathrm{~min}$ & 1.36 & 4.11 \\
\hline 11,850 & $15^{\text {th }}$ St. Bridge & $\begin{array}{l}\text { On-site obs., } \\
\text { Temp }\end{array}$ & $2 / 11 / 2013$ at 1155 & 21 hr 35 min & 1.39 & 2.87 \\
\hline 6520 & $5^{\text {th }}$ St. East Bridge & On-site obs. & $2 / 11 / 2013$ at 1224 & $22 \mathrm{hr} 4 \mathrm{~min}$ & 1.43 & 3.06 \\
\hline \multirow[t]{2}{*}{3100} & Siphon & On-site obs. & $2 / 11 / 2013$ at 1246 & 22 hr $26 \min$ & 1.45 & 2.59 \\
\hline & $5^{\text {th }}$ St. West Bridge & $\begin{array}{l}\text { On-site obs., } \\
\text { Stage }\end{array}$ & & & & \\
\hline 80 & Mouth & Stage & $2 / 11 / 2013$ at 1315 & 22 hr 55 min & 1.45 & 1.74 \\
\hline
\end{tabular}

\subsubsection{Propagation of discharge modifications made after the Initial Release Wave}

The initial outlet discharge of 150 cfs was held constant for $29 \mathrm{hr}$ and 10 min and then was increased rapidly to 300 cfs at 1930 on 11 February 2013. It is difficult to discern exactly the arrival of the $300 \mathrm{cfs}$ discharge wave at the downstream USGS gages for two reasons. One, the transient set in motion following the propagation downstream of the IRW obscures the arrival of the step increase to $300 \mathrm{cfs}$. The second reason is that the sharp front of the step increase to $300 \mathrm{cfs}$ tended to flatten out as it traveled downstream. Given these difficulties, the arrival of the step increase to $300 \mathrm{cfs}$ was determined by two events: the arrival of the leading edge and the arrival of the flow increase itself. The leading edge was identified as the point where the discharge at the downstream gages began to in- 
crease steadily above the low point of the transient. The wave arrival was identified by the point when the discharge at the gages reached approximately 300 cfs. The 300 cfs flow release propagated at a faster velocity than the IRW. The step increase to 300 cfs arrived at the mouth of Willow Creek at 0730 on 12 February 2013 after a travel time of $12 \mathrm{hr}$ and an average wave celerity of $2.8 \mathrm{fps}$. Table 5 and Figure 32 (red lines) show the step increase to 300 cfs.

The 300 cfs outflow was held constant for $14 \mathrm{hr}$ and $30 \mathrm{~min}$ and then was increased rapidly to $500 \mathrm{cfs}$ at 1000 on 12 February 2013. The $500 \mathrm{cfs}$ flow release propagated at a faster velocity than the IRW and at a slightly faster velocity than the step increase to $300 \mathrm{cfs}$. The step increase to $500 \mathrm{cfs}$ arrived at the mouth of Willow Creek at 2115 on 12 February 2013 after a travel time of $11 \mathrm{hr}$ and $15 \mathrm{~min}$ and an average wave celerity of $3.0 \mathrm{fps}$. Table 5 and Figure 32 (blue lines) show the step increase to 500 cfs.

The 500 cfs outflow was held constant for $24 \mathrm{hr}$ and $30 \mathrm{~min}$, and then the flow out of Ririe Dam was shut off at 1030 on 13 February 2013. The arrival of the shutoff at the downstream gages was determined as the time when the discharge began to drop below the approximately 500 cfs constant discharge recorded at the gages. The shutoff propagated at a faster velocity than the IRW and a faster velocity than either of the two previous step increases. The shutoff arrived at the mouth of Willow Creek at 1645 on 13 February 2013 after a travel time of $6 \mathrm{hr}$ and $15 \mathrm{~min}$ and an average wave celerity of $5.3 \mathrm{fps}$. Table 5 and Figure 32 (black lines) also show the shutoff. 
Table 5. Summary of propagation of discharge modifications made after the IRW.

\begin{tabular}{|c|c|c|c|c|c|c|c|}
\hline \multicolumn{8}{|c|}{$300 \mathrm{cfs}$} \\
\hline $\begin{array}{c}\text { Distance } \\
\text { (ft) }\end{array}$ & USGS Gage & Leading Edge Arrival & Wave Arrival & $\begin{array}{c}\text { Total Travel } \\
\text { Time }\end{array}$ & \multicolumn{2}{|c|}{$\begin{array}{c}\text { Average } \\
\text { Velocity (fps) }\end{array}$} & $\begin{array}{c}\text { Velocity } \\
\text { (between gages) }\end{array}$ \\
\hline 120,000 & 13058000 & $2 / 11 / 2013$ at 1930 & $2 / 11 / 2013$ at 1930 & & & & \\
\hline 36,000 & 13058520 & $2 / 12 / 2013$ at 0045 & $2 / 12 / 2013$ at 0630 & $11 \mathrm{hr}$ & 2.1 & & 2.1 \\
\hline 80 & 13058529 & $2 / 12 / 2013$ at 0330 & $2 / 12 / 2013$ at 0730 & $12 \mathrm{hr}$ & 2.8 & & 10.0 \\
\hline \multicolumn{8}{|c|}{$500 \mathrm{cfs}$} \\
\hline $\begin{array}{c}\text { Distance } \\
\text { (ft) }\end{array}$ & USGS Gage & Leading Edge Arrival & Wave Arrival & $\begin{array}{l}\text { Total Travel } \\
\text { Time }\end{array}$ & \multicolumn{2}{|c|}{$\begin{array}{c}\text { Average } \\
\text { Velocity (fps) }\end{array}$} & $\begin{array}{c}\text { Velocity } \\
\text { (between gages) }\end{array}$ \\
\hline 120,000 & 13058000 & $2 / 12 / 2013$ at 1000 & $2 / 12 / 2013$ at 1000 & & & & \\
\hline 36,000 & 13058520 & $2 / 12 / 2013$ at 1300 & $2 / 12 / 2013$ at 2000 & $10 \mathrm{hr}$ & \multicolumn{2}{|l|}{2.3} & 2.3 \\
\hline 80 & 13058529 & $2 / 12 / 2013$ at 1400 & $2 / 12 / 2013$ at 2115 & $11.25 \mathrm{hr}$ & \multicolumn{2}{|l|}{3.0} & 8.0 \\
\hline \multicolumn{8}{|c|}{ Shutoff } \\
\hline $\begin{array}{c}\text { Distance } \\
\text { (ft) }\end{array}$ & USGS Gage & Leading Edge Arrival & Total Travel Time & \multicolumn{2}{|c|}{ Average Velocity (fps) } & \multicolumn{2}{|c|}{$\begin{array}{c}\text { Velocity } \\
\text { (between gages) }\end{array}$} \\
\hline 120,000 & 13058000 & $2 / 13 / 2013$ at 1030 & & & & & \\
\hline 36,000 & 13058520 & $2 / 13 / 2013$ at 1445 & $4 \mathrm{hr} 15 \mathrm{~min}$ & \multicolumn{2}{|l|}{5.5} & \multicolumn{2}{|l|}{5.5} \\
\hline 80 & 13058529 & $2 / 13 / 2013$ at 1645 & $6 \mathrm{hr} 15 \mathrm{~min}$ & \multicolumn{2}{|l|}{5.3} & \multicolumn{2}{|l|}{5.0} \\
\hline
\end{tabular}

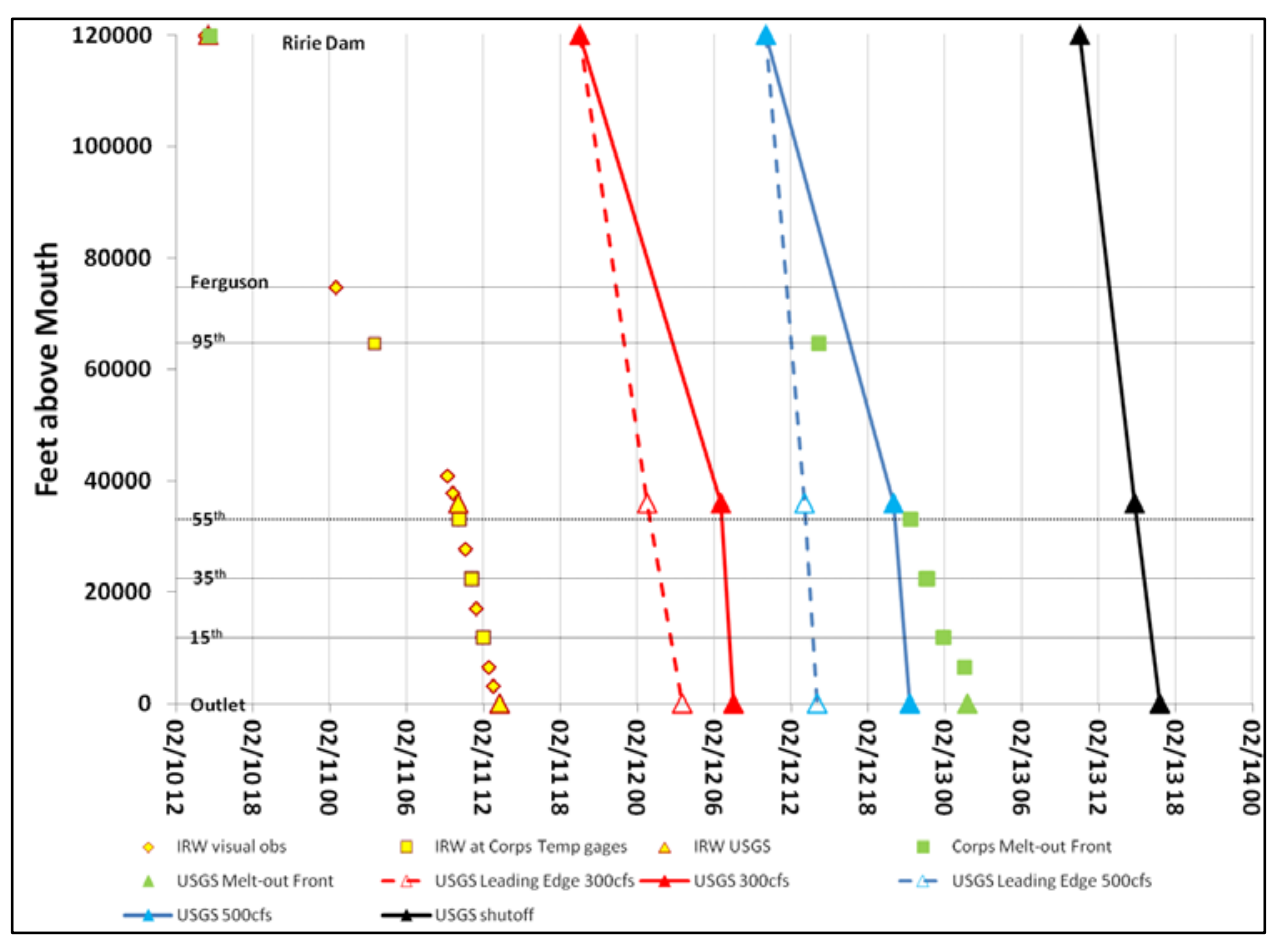

Figure 32. Observed Initial Release Wave, flow changes, and the advance of the melt-out front. 


\subsection{Ice conditions}

The snow and ice conditions in Willow Creek during the Release Test can be divided into two phases: an ice and water phase, when ice and water coexisted, and a melt-out phase, when the warm water released from Ririe Dam had melted out the snow and ice in the channel. The ice and water phase followed passage of the IRW and continued while the water temperature remained at $32^{\circ} \mathrm{F}\left(0^{\circ} \mathrm{C}\right)$. During this phase, the ice and snow cover in place prior to the Release Test remained in place; slush ice traveled at the surface of the flowing water; heat transfer from the water surface to the atmosphere generated new ice; and floating ice collected at the Ferguson Road Bridge, the check dam upstream of the Bifurcation, and to a lesser extent, at the Siphon. It is during this phase that significant blockages to flow by snow and ice could occur.

The melt-out phase was occurring in all sub-reaches of the channel upstream of the $32^{\circ} \mathrm{F}\left(0^{\circ} \mathrm{C}\right)$ water temperature isotherm. As described above, the water temperature of the outflow from Ririe Dam was higher than $38.4^{\circ} \mathrm{F}\left(3.54^{\circ} \mathrm{C}\right)$ throughout the Release Test. However, contact with ice and snow in the channel lowered this water temperature to $32^{\circ} \mathrm{F}\left(0^{\circ} \mathrm{C}\right)$. As the ice and snow melted out, the leading edge of the warm water $\left(\right.$ the $32^{\circ} \mathrm{F}$ $\left[0^{\circ} \mathrm{C}\right]$ isotherm) was convected further and further downstream. Upstream of the $32^{\circ} \mathrm{F}\left(0^{\circ} \mathrm{C}\right)$ isotherm, the snow and ice had melted out; and the channel was effectively ice free. Downstream of the $32^{\circ} \mathrm{F}\left(0^{\circ} \mathrm{C}\right)$ isotherm, snow and ice remained in the channel. The $32^{\circ} \mathrm{F}\left(0^{\circ} \mathrm{C}\right)$ isotherm reached the mouth of Willow Creek Floodway Channel at 0145 on 13 February 2013 after a travel time of $59 \mathrm{hr}$ and $15 \mathrm{~min}$. After this time, the entire Willow Creek flood control system was effectively ice free.

\subsubsection{Ice and water phase}

As noted above, the snow in the channel remained in place during and after the IRW traveled through each section. Neither the IRW nor the subsequent flow significantly removed, dislodged, or eroded away the snow that was in place prior to the Release Test. This required the IRW and all subsequent flow to travel on top of the snow and around any snow drifts in place. This condition remained at each section until the arrival of warm water, which melted out the snow at that location. It may be that some of the slush ice that floated on the water surface after the IRW had propagated through a section had originated from the snow that was in place prior to the Release Test. However, this floating slush ice could have also origi- 
nated through ice formation resulting from heat transfer during the period of frigid air temperatures (Fig. 30).

The snow in the channel remained in place and did not change with time until the warm water arrived. This snow was a static obstruction to the flow. However, the floating ice conditions in the channel did change dynamically with time. Appendix B lists observations of the ice conditions. Figure 33 displays these observations and shows the percentage of the water surface covered by ice. All ice observations were of moving slush ice except upstream of the $115^{\text {th }}$ St. Bridge (88,480 $\mathrm{ft}$ above the mouth), at the Ferguson Bridge (74,700 ft), and the check dam $(42,200 \mathrm{ft})$. At these three locations, the ice was stationary, as described below.

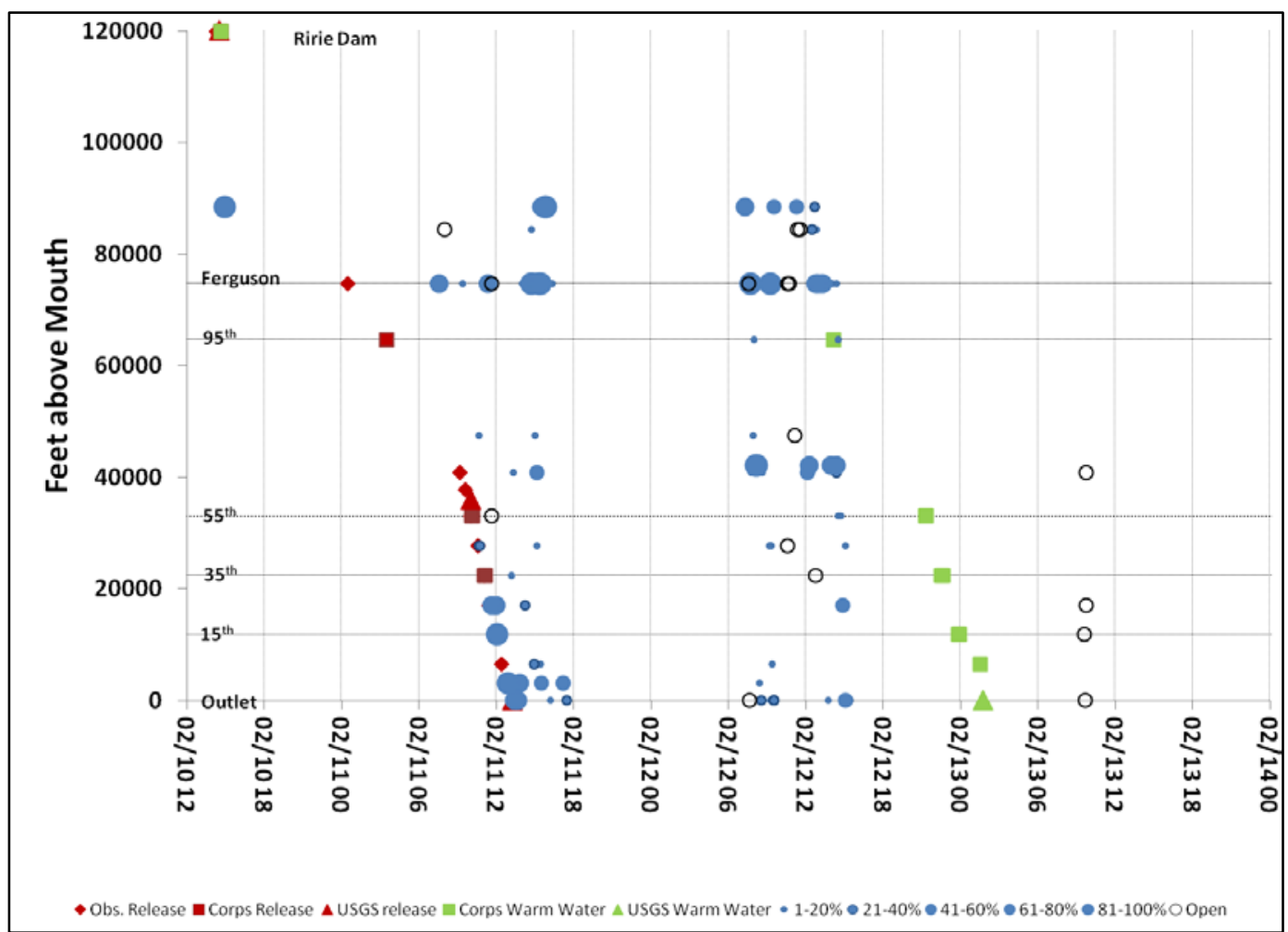

Figure 33. Ice observation summary. 


\subsubsection{Upstream of the $115^{\text {th }}$ St. Bridge}

As described above, an ice cover was in place in the canyon section of the Willow Creek natural channel prior to the Release Test. The reach is located downstream of Ririe Dam and upstream of the $115^{\text {th }}$ St. Bridge. When the IRW passed through this section, it caused the ice cover to fracture as the ice along the channel centerline was lifted and the ice at the banks remained frozen in place. The portion of the ice cover nearest to the banks became submerged while the middle third remained above water (Fig. 34). In general, a single longitudinal crack that ran down the center of the channel ice cover fractured the ice cover. At wider locations, two longitudinal cracks were observed, each spaced about one quarter to one third of the channel width from the channel banks. When the melt-out front reached this ice, the ice generally melted in place, although the front transported some small percentage of the ice cover downstream.

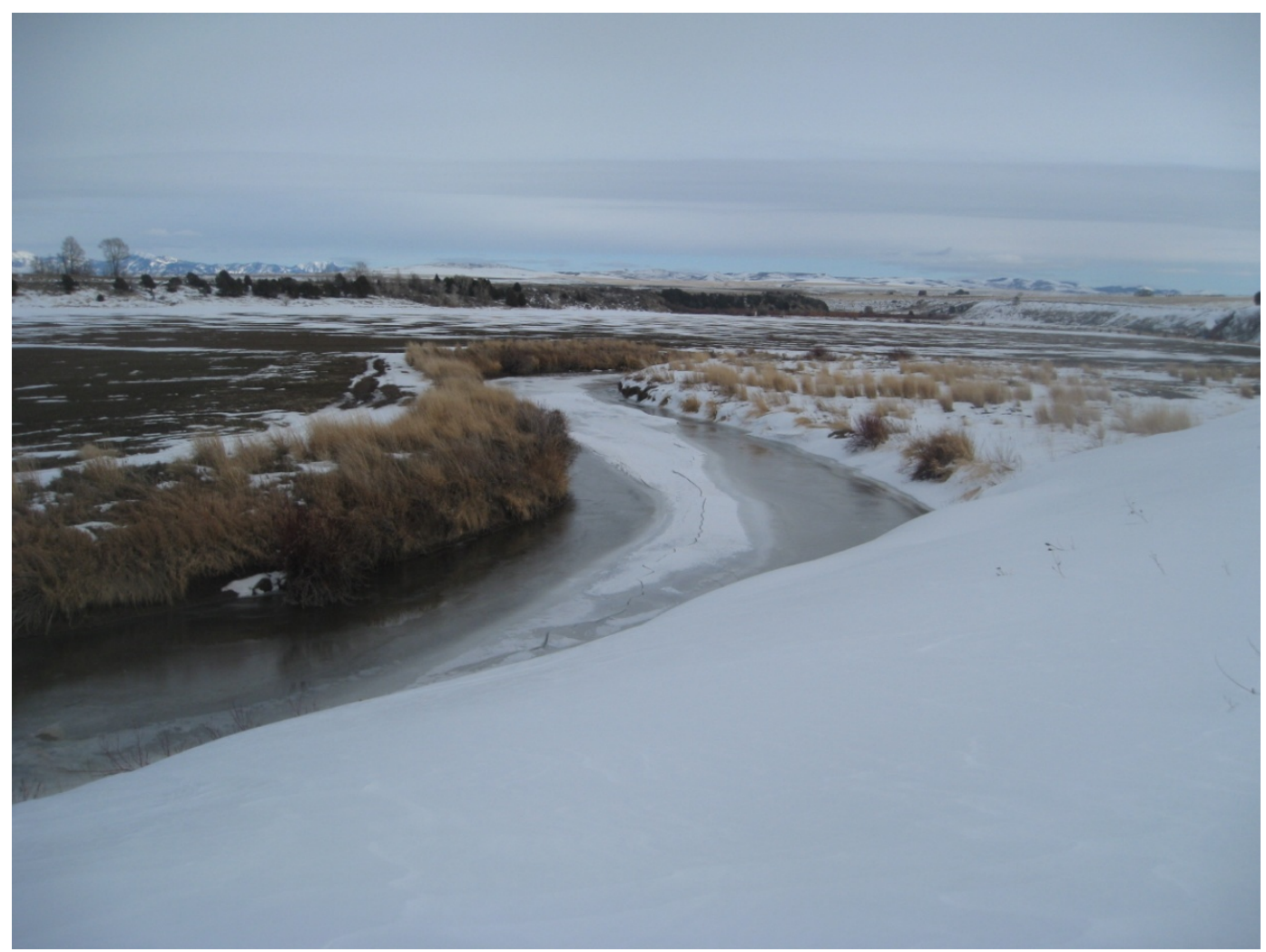

Figure 34. Ice cover upstream of the $115^{\text {th }}$ St. Bridge after passage of the IRW. Note portions near banks flooded and central longitudinal crack. 


\subsubsection{Immediately downstream of the Ferguson St. Bridge}

A large depression covering the width of the Willow Creek channel and having strong downstream control existed in this location. This reduced the flow velocity in this reach and provided a location where slush ice could accumulate. A hanging dam-type ice formation formed and grew at this location. When the melt-out front reached this location, the hanging dam melted in place although the front transported a small percentage of the ice cover downstream. Figure 35 displays the steps in the evolution of the floating ice at this location. This ice cover did cause the upstream water levels to rise but did not produce any out of bank flooding.

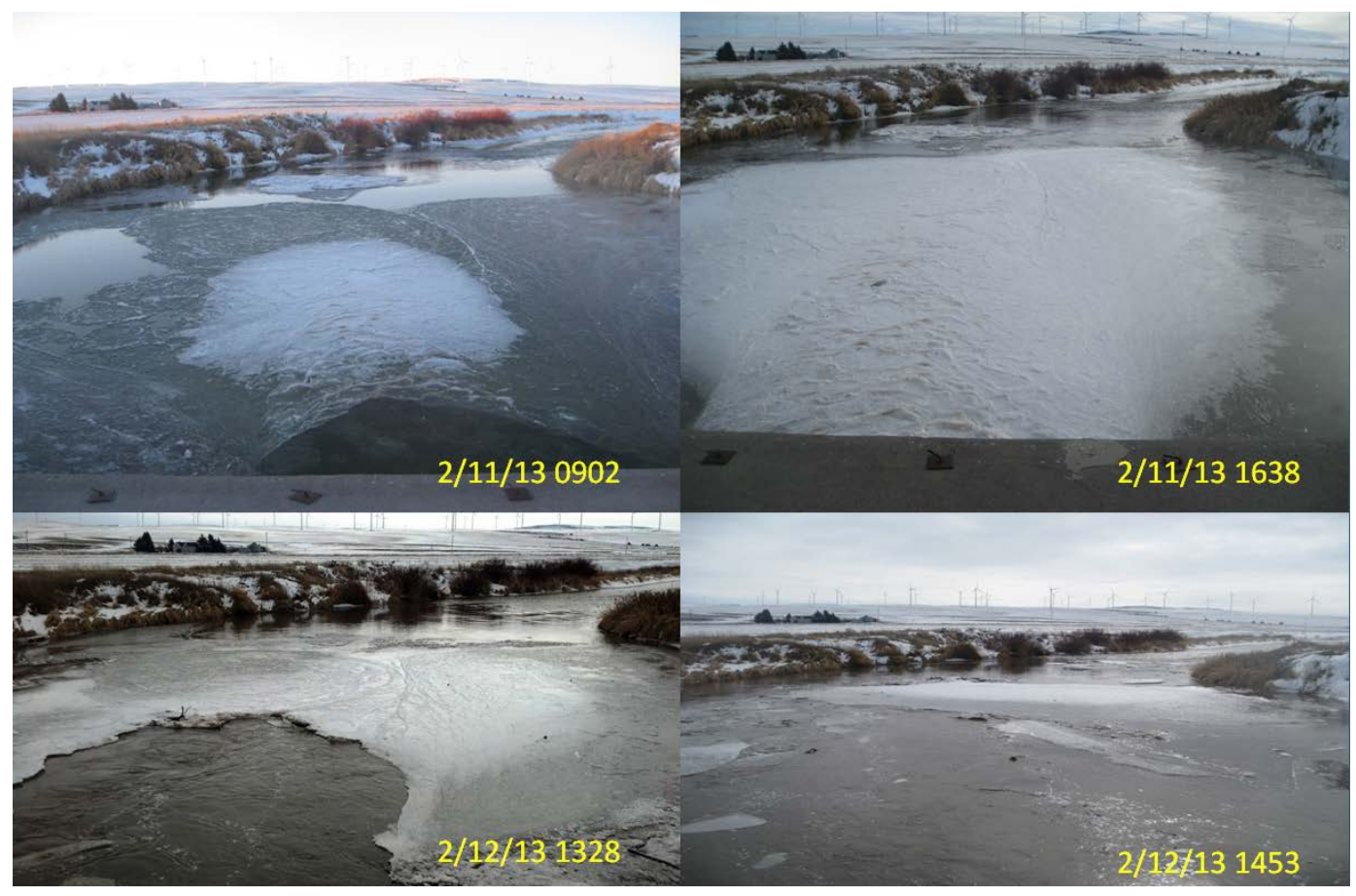

Figure 35. Evolution of the hanging ice dam immediately downstream of the Ferguson Bridge.

\subsubsection{The check dam}

A rock check dam extends across the entire width of Willow Creek about 0.4 miles upstream of the Bifurcation. This check dam raises the upstream water level about $3 \mathrm{ft}$. Floating slush ice accumulated upstream of the check dam, and accumulation extended upstream about 0.25 miles (Fig. 36). This ice melted in place when the melt-out front reached this location. 


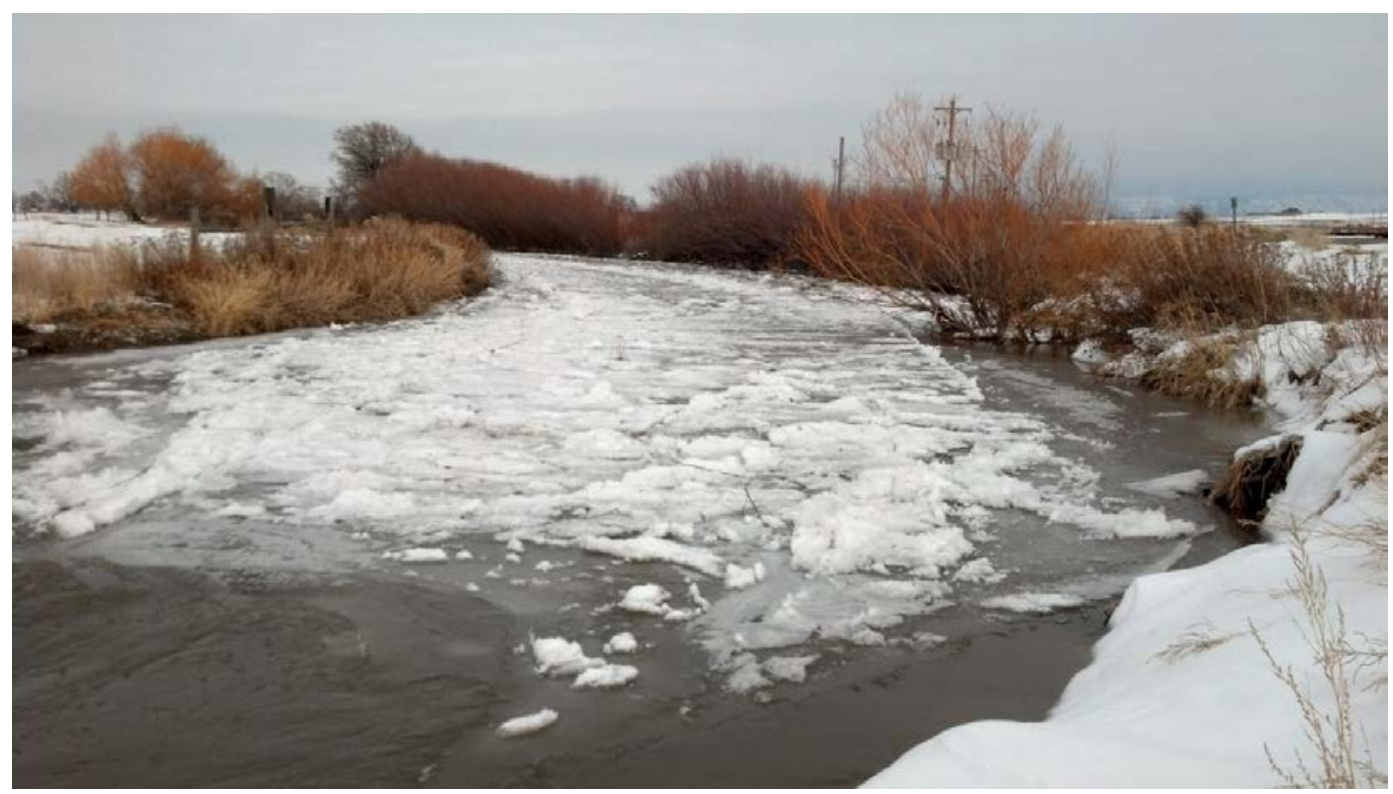

Figure 36. Ice cover in place upstream of the check dam (looking upstream).

\subsubsection{The siphon}

Slush ice accumulated at the siphon when the IRW first inundated the siphon passage (Fig. 37). No ice was observed to exit the siphon for approximately 10 to $15 \mathrm{~min}$ after the IRW reached this location. After this time, slush ice appeared to transit the siphon without difficulty and not to accumulate further.

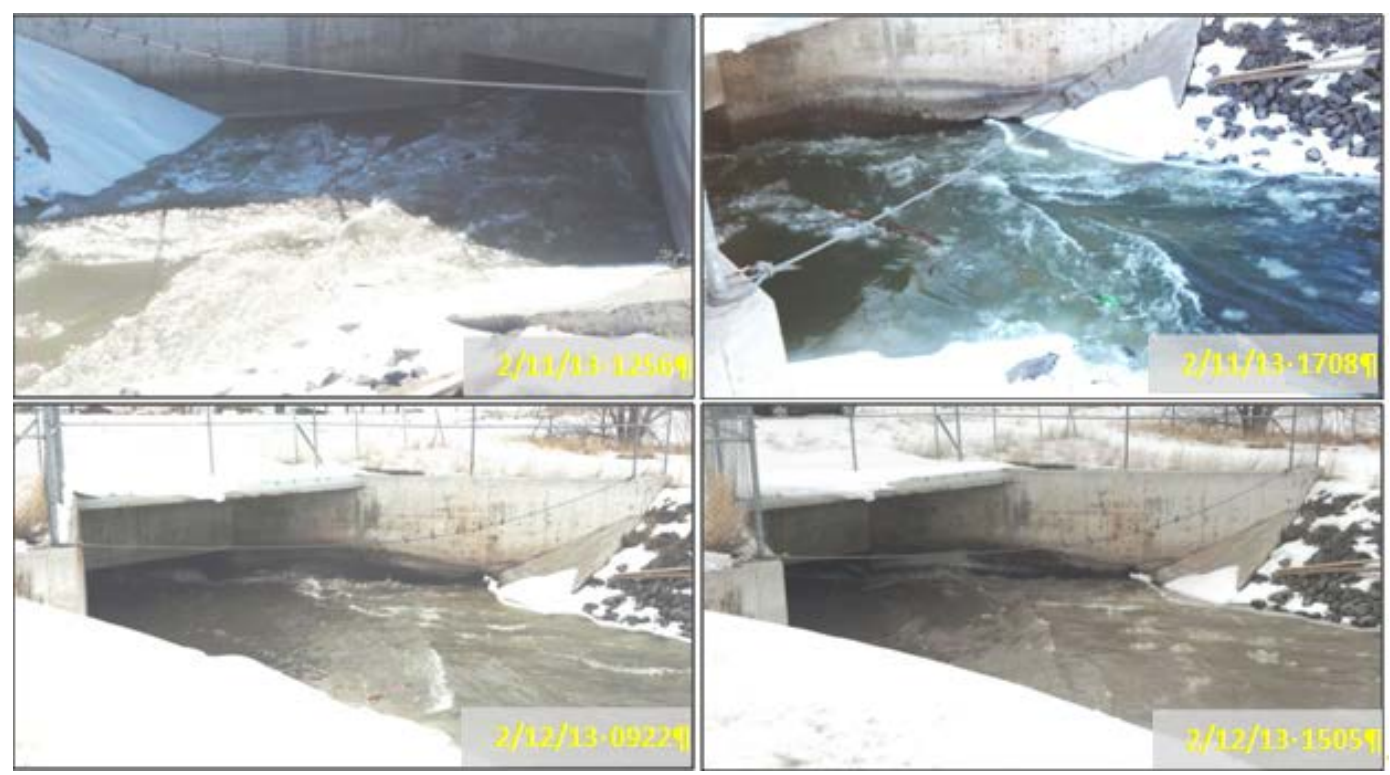

Figure 37. Ice upstream of the siphon. 


\subsubsection{The mouth of Willow Creek at the Snake River}

Immediately after the arrival of the IRW, a large snow drift located immediately downstream of the weir crest located at the downstream end of Willow Creek impeded the passage of water out of the Willow Creek Outflow Channel into the Snake River. This snow drift took almost an hour to erode away even though the flow dropped from the weir crest directly onto the drift at high velocity. It is likely that while the drift was in place, it increased upstream water levels.

At the time of the Release Test, a competent, intact, and level ice cover that extended from bank to bank and for a considerable distance upstream and downstream covered the Snake River. The flow from Willow Creek out onto the Snake River ice cover went through several stages. Initially, the water flowed out over the Snake River and inundated a wide area reaching past the center of the channel and for some distance up and downstream. The flow then apparently found (or created) several passages through the ice cover, and the inundated area was reduced in size. Eventually, the inundated area was reduced to an area located right at the mouth of the Outflow Channel (Fig. 38). When the melt-out front reached the mouth, it melted out a relatively compact opening in the Snake River ice cover immediately at the mouth of Willow Creek. Following this, all the flow passed through this opening. 


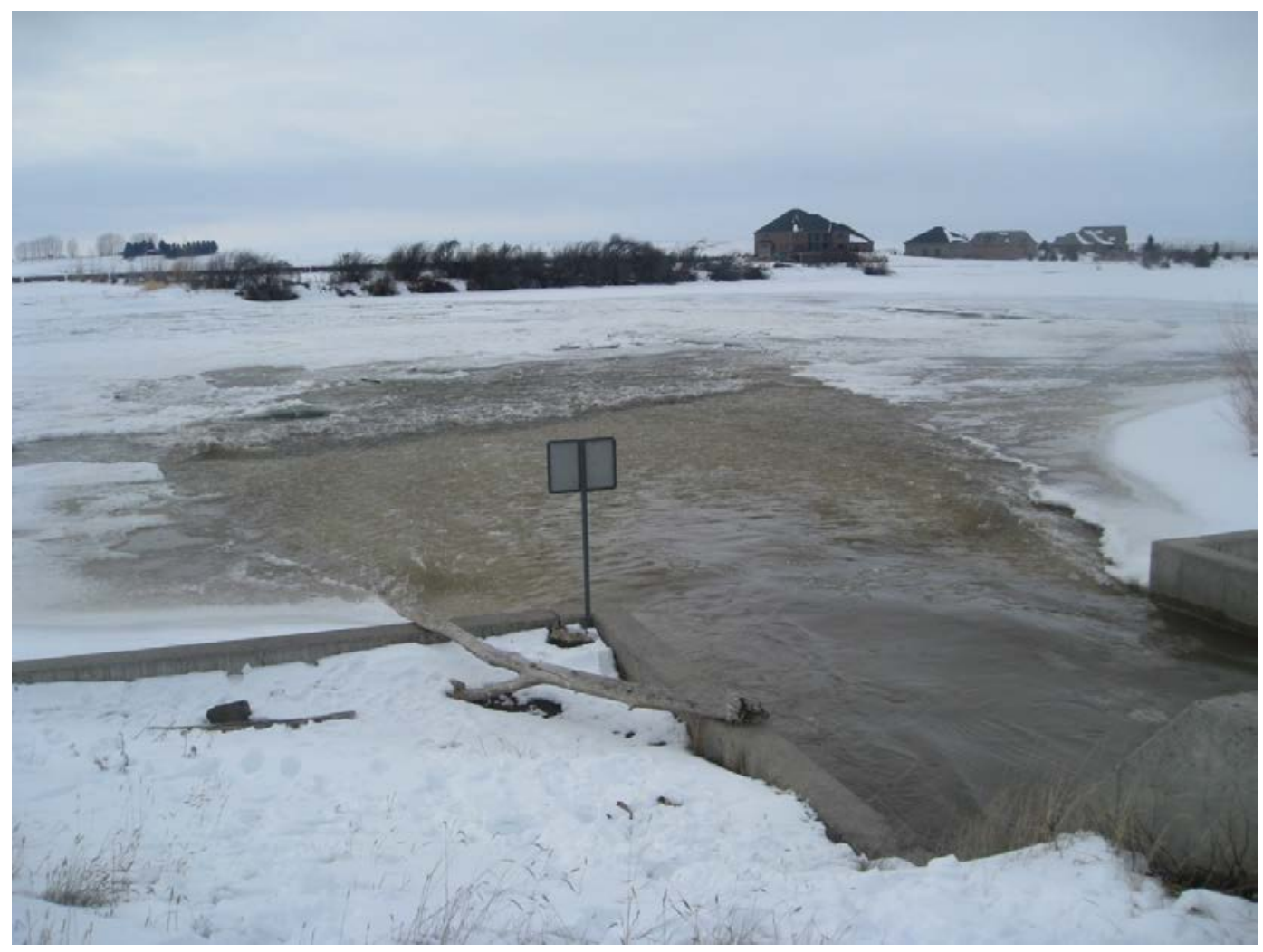

Figure 38. Willow Creek flow through Snake River ice cover, 12 February 2012 at 1630.

\subsubsection{Melt-out phase}

The melt-out phase began immediately downstream of Ririe Dam at the start of the Release Test. The melt-out phase describes all reaches of the channel upstream of the melt-out front defined by the $32^{\circ} \mathrm{F}\left(0^{\circ} \mathrm{C}\right)$ water temperature isotherm. The rate of advance of the melt-out front depended on the outflow rate, the outflow water temperature, the amount of snow and ice in the channel, and the rate of heat transfer to the air. The more snow and ice in the channel and the greater the heat loss to the atmosphere, the slower the melt-out front would advance downstream. It is possible that if the air temperatures were cold enough or the reservoir temperatures were cold enough, the melt-out front would stop advancing downstream and could even retreat.

Table 6 provides a summary of the data describing the advancement of the melt-out front down the channel and Figure 32 displays the melt-out front advancement. The melt-out front advanced slowly in the upstream canyon section of the natural channel sub-reach of Willow Creek where the rate of progress was roughly $0.32 \mathrm{fps}$. This slow rate probably reflected the balance between the heat released by Ririe Dam and heat either absorbed by 
the melting ice cover (measured at 16 in. thick) or lost to the cold air above. Observations of the ice cover on 12 February in this section indicated that the ice cover was in fact melting out. When the $32^{\circ} \mathrm{F}\left(0^{\circ} \mathrm{C}\right)$ water temperature isotherm reached the Floodway Channel, its advance rate was generally faster. This reflected the fact that the snow cover in place represented less ice to melt, and the air temperatures were generally warmer during this period. Images taken of the Willow Creek channel after the completed Release Test confirm that the snow and ice in the channel had indeed melted out by the end of the Release Test (Fig. 39 and 40).

Table 6. Summary of melt-out front advance.

\begin{tabular}{|l|l|l|l|l|l|}
\hline $\begin{array}{c}\text { Distance } \\
(\mathrm{ft})\end{array}$ & \multicolumn{1}{|c|}{ Location } & \multicolumn{1}{|c|}{$\begin{array}{c}\text { Arrival } \\
\text { Date Time }\end{array}$} & $\begin{array}{c}\text { Total Travel } \\
\text { Time }\end{array}$ & $\begin{array}{c}\text { Average } \\
\text { Velocity } \\
\text { (fps) }\end{array}$ & $\begin{array}{c}\text { Velocity } \\
\text { (Between } \\
\text { sites) }\end{array}$ \\
\hline 119,880 & Ririe Dam & $2 / 10 / 2013$ at 1440 & $0 \mathrm{hr}$ & & \\
\hline 64,700 & $\mathrm{~N} 95^{\text {th }} \mathrm{E}$ & $2 / 12 / 2013$ at 1410 & $47 \mathrm{hr} 30 \mathrm{~min}$ & 0.32 & 0.32 \\
\hline 33,020 & $55^{\text {th }}$ St. Bridge & $2 / 12 / 2013$ at 2120 & $54 \mathrm{hr} 40 \mathrm{~min}$ & 0.44 & 1.23 \\
\hline 22,430 & Highway 42 Bridge & $2 / 12 / 2013$ at 2240 & $56 \mathrm{hr} 00 \mathrm{~min}$ & 0.48 & 2.21 \\
\hline 11,850 & $15^{\text {th }}$ St. Bridge & $2 / 12 / 2013$ at 2350 & $57 \mathrm{hr} 10 \mathrm{~min}$ & 0.52 & 2.52 \\
\hline 6520 & $5^{\text {th }}$ St. East Bridge & $2 / 13 / 2013$ at 0130 & $58 \mathrm{hr} 50 \mathrm{~min}$ & 0.54 & 0.89 \\
\hline 80 & Mouth & $2 / 11 / 2013$ at 0145 & $59 \mathrm{hr} 15 \mathrm{~min}$ & 0.56 & 0.32 \\
\hline
\end{tabular}




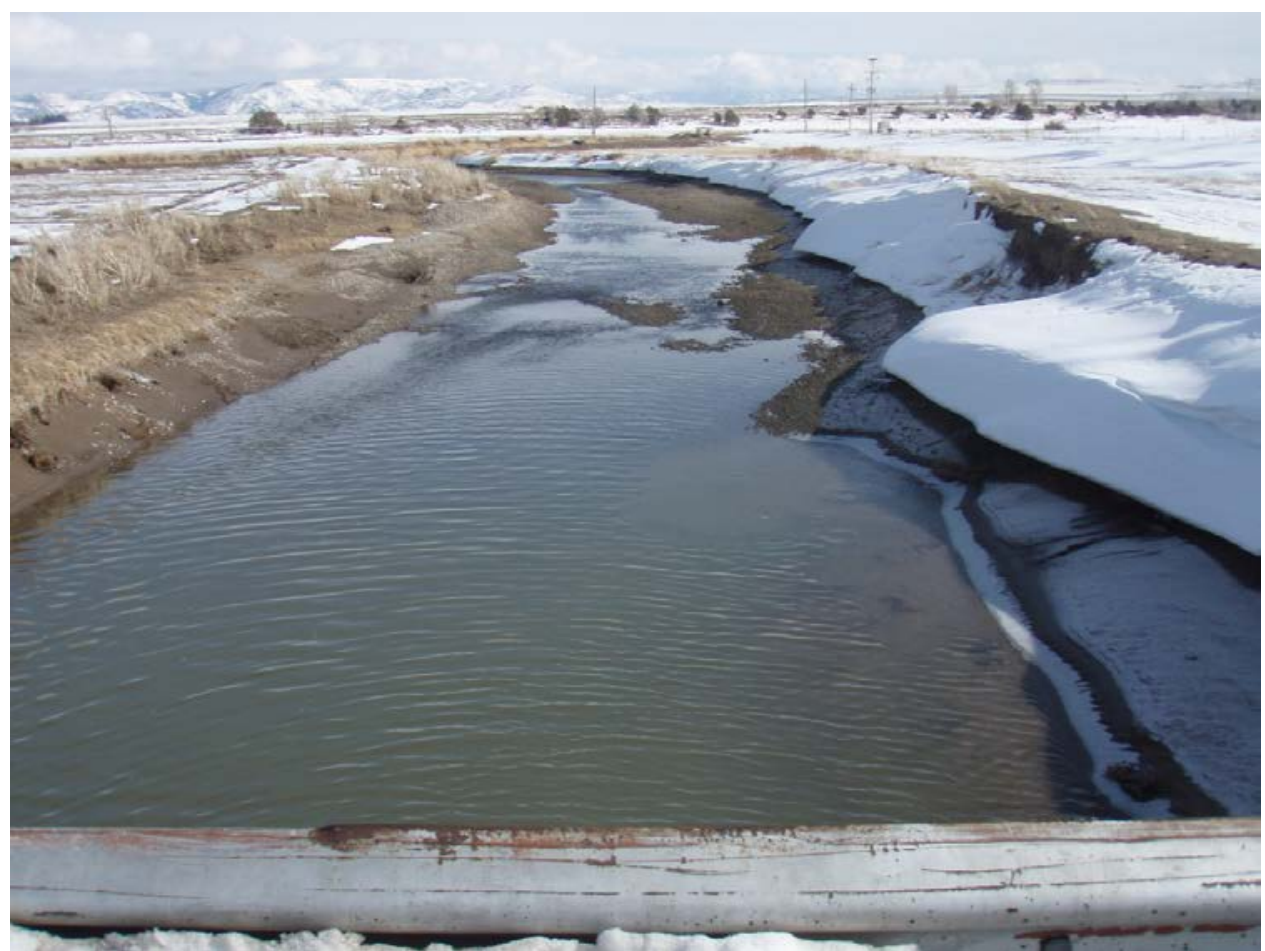

Figure 39. Looking upstream from the $115^{\text {th }}$ St. Bridge after the Release Test. (Image by P. Cooper.)

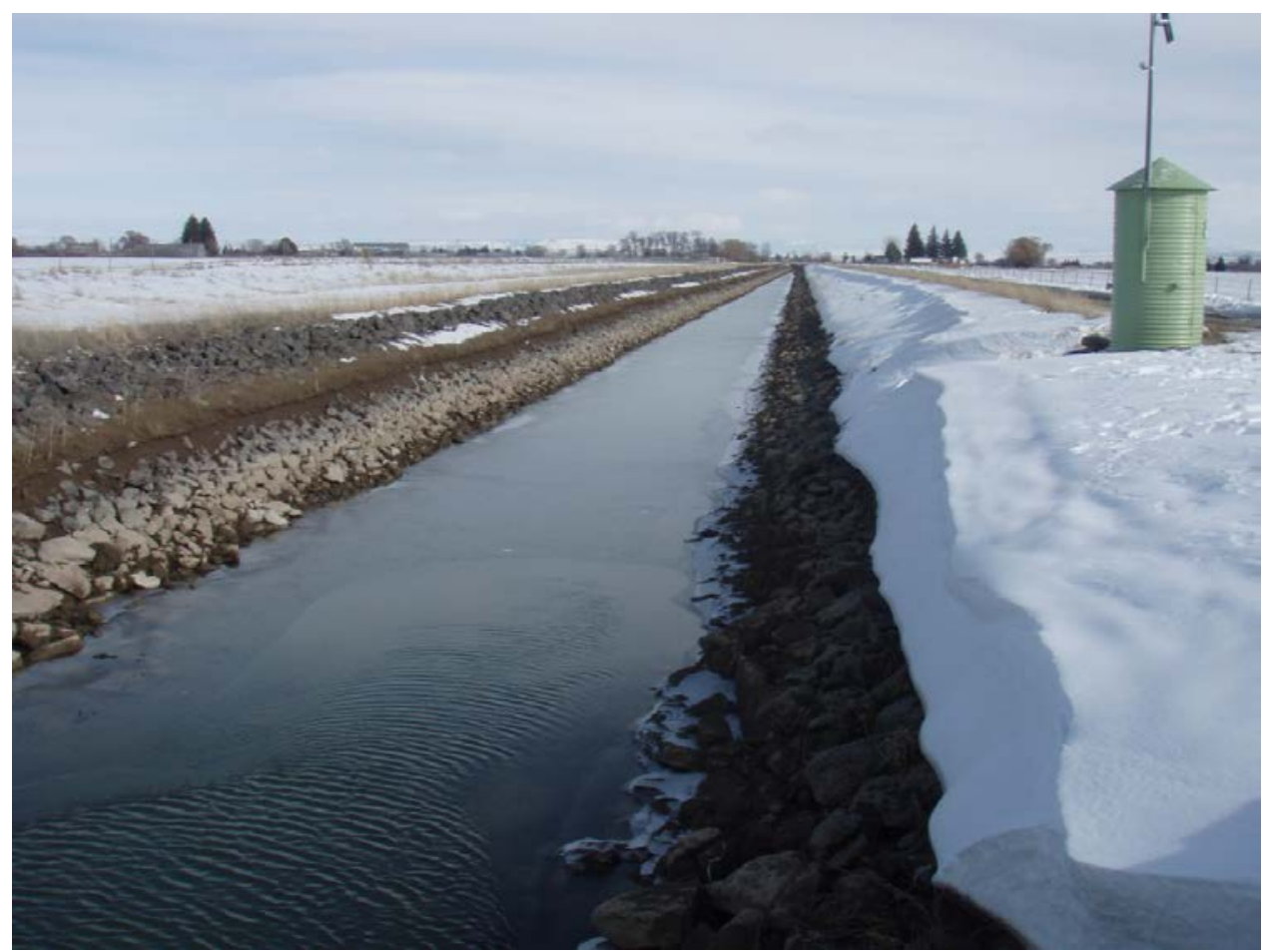

Figure 40. Looking upstream from the mouth of the Floodway Channel after the Release Test. (Image by P. Cooper.) 


\section{Comparison with the 2011 Release}

In February 2011, there was an Operational Release from Ririe Dam to bring the reservoir contents back down below the winter flood control rule curve (Cooper 2013). This release occurred from approximately 07 February 2011 until 09 February 2011 (Swenk 2011). The test began at 2200 on 7 February 2011 with a step increase out of Ririe Dam of 150 cfs. This outflow was held constant until 1245 on 8 February 2011 when the outflow was increased to approximately $240 \mathrm{cfs}$. This flow was held constant until 1400 on 9 February 2011 when the outflow was shut off. The release flow was suspended because flooding occurred in Floodway Channel of the Willow Creek. It is interesting to compare the 2011 experience with the 2013 experience to gain insight into the possible causes of the flooding in 2011.

Not all of the data available in 2013 is available for the 2011 release. The water temperature in Ririe Reservoir was not measured prior to the release. In fact, the Ririe Reservoir temperature is not routinely measured in the winter; and the 2012- 2013 winter measurements are unique. No record is available of the snow and ice conditions in Willow Creek before the 2011 release. The USGS gages did not record water temperature, and only daily discharges are available for the period of the release. The daily air temperature record from the Idaho Falls Municipal Airport for both years is available from the NWS. Figure 41 shows the air temperature record for each winter season. These records are very similar overall. Table 7 lists the daily maximum and minimum temperatures during the days of the tests. In 2011 , the air temperature was quite low $\left(-14.1^{\circ} \mathrm{F}\left[-25.6^{\circ} \mathrm{C}\right]\right)$ on the day the release flow was shut off (9 February 2011). 


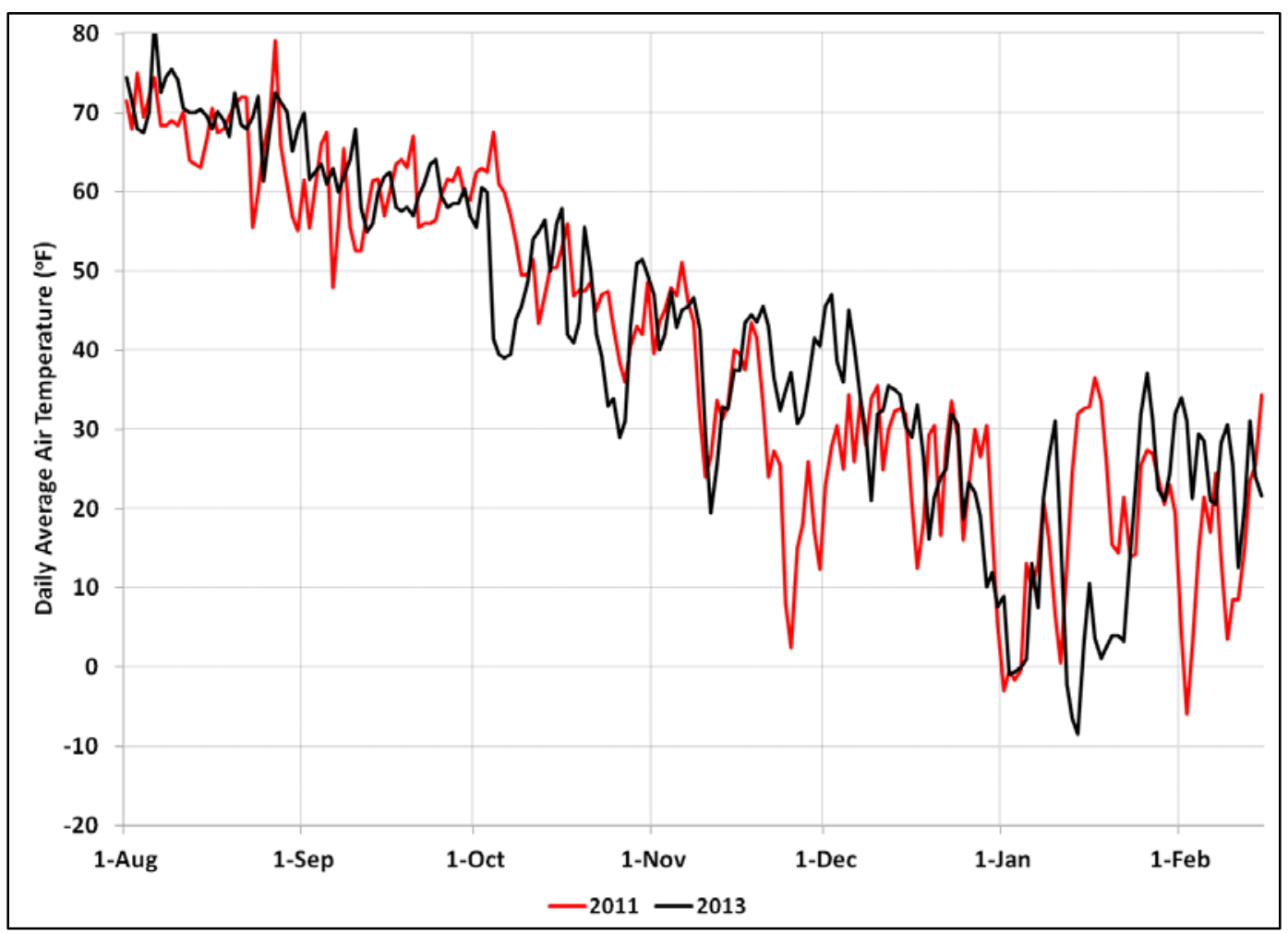

Figure 41. Daily average air temperatures leading up to the releases of 2011 and 2013.

Table 7. Comparison of daily maximum and minimum temperatures in 2011 and 2013.

\begin{tabular}{|l|l|l|l|l|l|c|}
\hline Day of Release & \multicolumn{1}{|c|}{ Date 2013 } & $\begin{array}{c}\text { Daily Max } \\
\text { Temp. }\left({ }^{\circ} \mathrm{F}\right)\end{array}$ & $\begin{array}{c}\text { Daily Min } \\
\text { Temp. }\left({ }^{\circ} \mathrm{F}\right)\end{array}$ & \multicolumn{1}{|c|}{ Date 2011 } & \multicolumn{1}{|c|}{$\begin{array}{c}\text { Daily Max } \\
\text { Temp. }\left({ }^{\circ} \mathrm{F}\right)\end{array}$} & $\begin{array}{c}\text { Daily Min } \\
\text { Temp. }\left({ }^{\circ} \mathrm{F}\right)\end{array}$ \\
\hline-2 & $2 / 8 / 2013$ & 35.6 & 21.0 & $2 / 5 / 2011$ & 27.0 & 16.0 \\
\hline-1 & $2 / 9 / 2013$ & 35.1 & 26.1 & $2 / 6 / 2011$ & 25.0 & 9.0 \\
\hline 1 & $2 / 10 / 2013$ & 32.0 & 19.0 & $2 / 7 / 2011$ & 30.9 & 18.0 \\
\hline 2 & $2 / 11 / 2013$ & 28.0 & -2.9 & $2 / 8 / 2011$ & 27.0 & 0.0 \\
\hline 3 & $2 / 12 / 2013$ & 30.0 & 10.4 & $\begin{array}{l}2 / 9 / 2011 \\
\text { (Release } \\
\text { shutoff })\end{array}$ & 21.0 & -14.1 \\
\hline 4 & & & $2 / 10 / 2011$ & 18.0 & -0.9 \\
\hline
\end{tabular}

Figure 42 shows the discharge records from Ririe Dam in 2011 and 2013. These discharge records are very similar in both years as there was no release from the dam after mid-November in either year. 


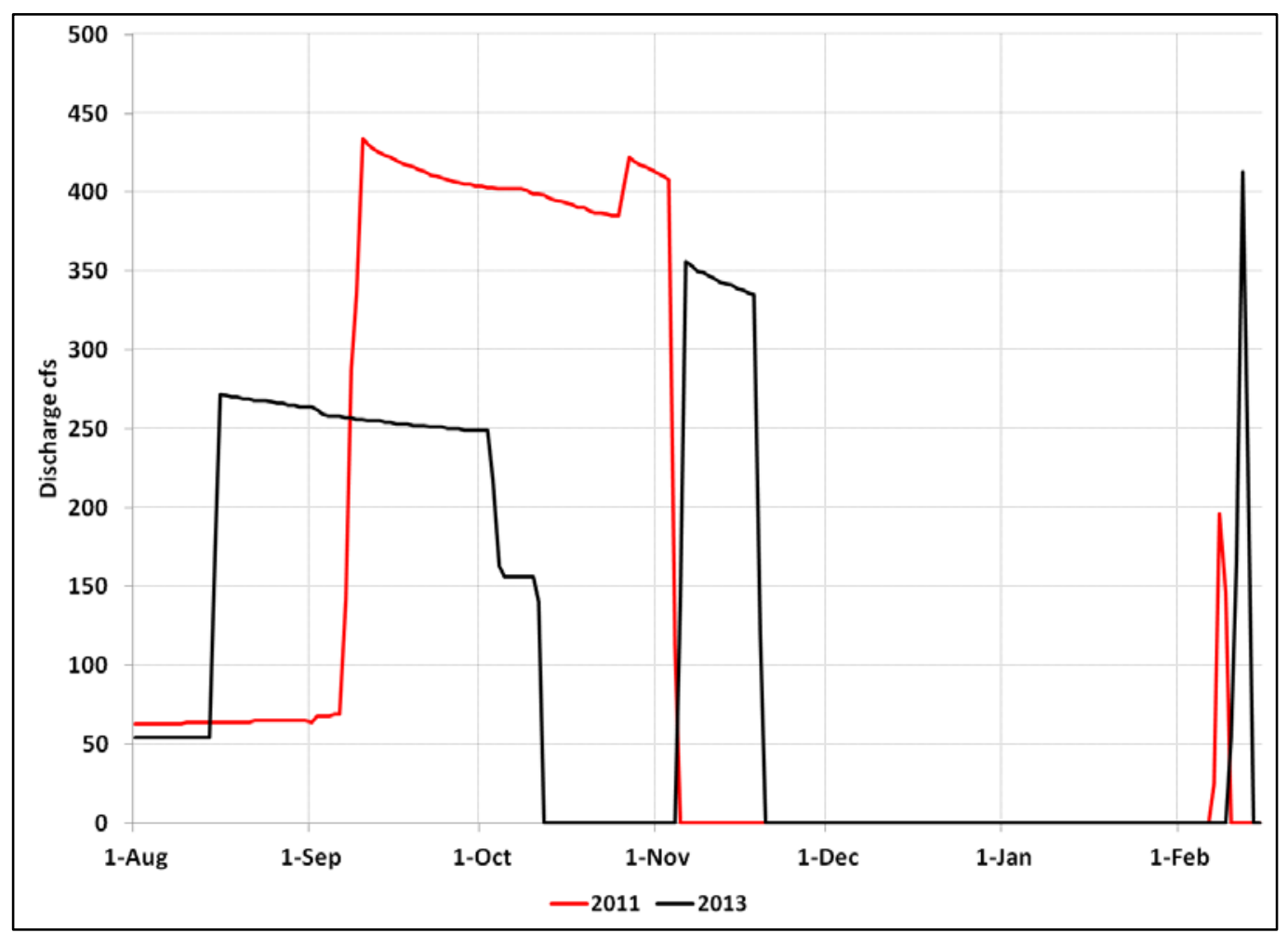

Figure 42. Daily discharge from Ririe Reservoir during the fall and winter of 2010-2011 and 2012-2013 leading up to the releases.

The IRW traveled at roughly the same speeds each year. The total travel time in 2013 was $22 \mathrm{hr}$ and $55 \mathrm{~min}$. In 2011 it is estimated to have taken between $23 \mathrm{hr}$ and $26 \mathrm{hr}$ (Table 8).

The major difference between 2011 and 2013 is probably the amount of snow in the channel prior to the releases. Unfortunately, there were no measurements of the snow conditions prior to the 2011 release. However, there are images of the snow remaining in the channel after the releases drained out in 2011 (Fig. 43) (Cooper 2013). These images show a relatively large blockage of snow following the release at the $25^{\text {th }}$ St. Bridge.

Table 8. Comparison of Initial Release Wave propagation in 2011 and 2013.

\begin{tabular}{|l|l|l|l|l|l|}
\hline $\begin{array}{c}\text { Distance } \\
(\mathrm{ft})\end{array}$ & \multicolumn{1}{|c|}{ Location } & \multicolumn{1}{|c|}{$\begin{array}{c}\text { Arrival 2013 } \\
\text { Date Time }\end{array}$} & $\begin{array}{c}\text { Total Travel } \\
\text { Time 2013 }\end{array}$ & \multicolumn{1}{|c|}{$\begin{array}{c}\text { Arrival 2011 } \\
\text { Date Time. }\end{array}$} & $\begin{array}{c}\text { Total Travel } \\
\text { Time 2011 }\end{array}$ \\
\hline 119,880 & Ririe Dam & $2 / 10 / 2013$ at 1420 & $0 \mathrm{hr}$ & $2 / 7 / 2011$ at 2200 & \\
\hline 84,480 & $115^{\text {th }}$ St. Bridge & & & $2 / 8 / 2011$ at 0600 & $8 \mathrm{hr}$ \\
\hline 74,700 & Ferguson Bridge & $2 / 11 / 2013$ at 0030 & $10 \mathrm{hr} 10 \mathrm{~min}$ & $2 / 8 / 2011$ at 0910 & $11 \mathrm{hr} 10 \mathrm{~min}$ \\
\hline 40,900 & Bifurcation & $2 / 11 / 2013$ at 0910 & $18 \mathrm{hr} 50 \mathrm{~min}$ & $2 / 8 / 2011$ at 1555 & $17 \mathrm{hr} 55 \mathrm{~min}$ \\
\hline 80 & Mouth & $2 / 11 / 2013$ at 1315 & $22 \mathrm{hr} 55 \mathrm{~min}$ & $\begin{array}{l}2 / 8 / 2011 \text { at } 2100-2400 \\
\text { (estimated) }\end{array}$ & $23-26 \mathrm{hr}$ \\
\hline
\end{tabular}




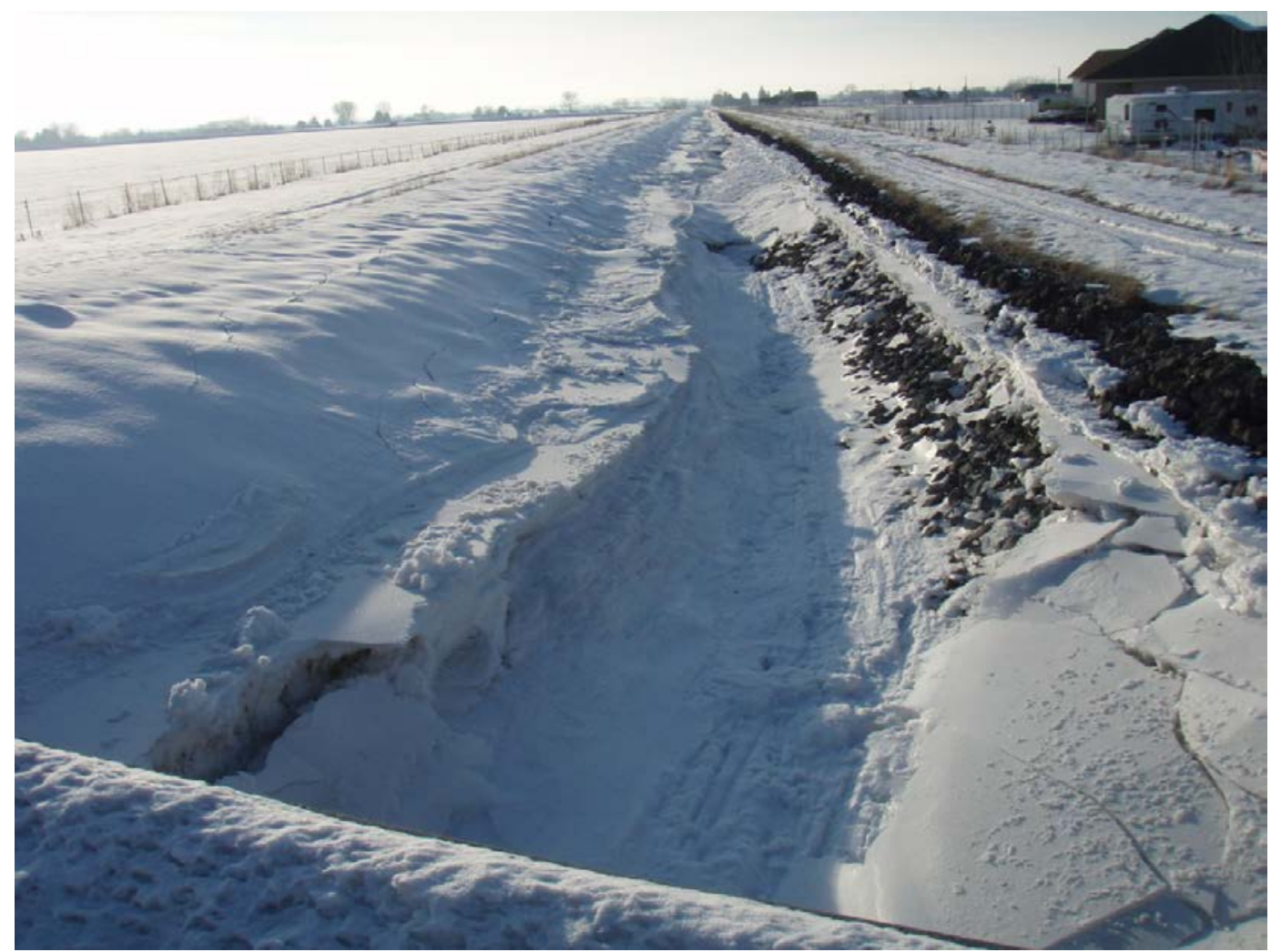

Figure 43. Snow remaining in Floodway Channel at $25^{\text {th }}$ St. Bridge following the release in 2011 (looking downstream). (Image by P. Cooper.) 


\section{Discussion of 2013 Results}

\subsection{Channel conveyance}

The natural sections and the Floodway section of Willow Creek have adequate conveyance to pass the required flows during the open water season when snow and ice is not present. An important finding from the $2013 \mathrm{Re}-$ lease Test was that the snow in the channel prior to the Release Test was not significantly removed, dislodged, or eroded away by the IRW or subsequent flow. The snow was melted out only after the thermal melt-out front had advanced downstream the length of the Willow Creek channel. This front advanced relatively slowly -it took over $59 \mathrm{hr}$ for the front to reach the mouth of Willow Creek. The snow in place prior to the thermal meltout front arrival can significantly impact the channel conveyance. It can affect the conveyance by changing the channel effective roughness and by blocking a portion of the channel cross section. It is thought that the snow acted to reduce the effective hydraulic roughness of the channel during the Release Test, especially in the Floodway Channel, which is lined with stone riprap. The riprap was essentially buried in snow on the south side of the channel, and the snow presented a much smoother surface. In this Release Test, the area blocked by snow did not cause significant blockages. Table 9 lists the area blocked by snow in each surveyed cross section. The net effect of these blockage patterns was to raise the water level in the channel about $0.5 \mathrm{ft}$ to $1.0 \mathrm{ft}$. The channel was not significantly blocked above these heights. At a height of about $4.5 \mathrm{ft}$, the approximate height at the maximum discharge of $500 \mathrm{cfs}$, less than $25 \%$ of the channel cross sectional area was blocked. Half of the surveyed sections had $15 \%$ or less of their cross sectional area blocked by snow at these stage heights. The net impact was to raise the stage and probably to increase the flow velocity. 
Table 9. Percentage of each surveyed cross section area blocked by snow with height above the channel invert.

\begin{tabular}{|c|c|c|c|c|c|c|c|c|c|c|c|}
\hline \multirow[b]{2}{*}{ Distance $(\mathrm{ft})$} & \multirow[b]{2}{*}{ Location } & \multicolumn{10}{|c|}{ \% Blocked at Height above Channel Invert (ft) } \\
\hline & & .5 & 1.0 & 1.5 & 2.0 & 2.5 & 3 & 3.5 & 4.0 & 4.5 & 5.0 \\
\hline 84,480 & $115^{\text {th }}$ St. Bridge & 100 & 70 & 47 & 35 & 27 & 22 & 20 & 19 & 17 & 15 \\
\hline 64,700 & $N 95^{\text {th }} \mathrm{E}$ & 41 & 22 & 16 & 13 & 13 & 10 & 9 & 8 & 7 & 6 \\
\hline 47,500 & N 85th $E$ & 99 & 97 & 82 & 58 & 45 & 36 & 31 & 27 & 24 & 21 \\
\hline 40,900 & Bifurcation & 97 & 58 & 39 & 29 & 23 & 19 & 17 & 15 & 13 & 12 \\
\hline 36,000 & USGS gage & 93 & 62 & 43 & 32 & 26 & 22 & 20 & 18 & 17 & 16 \\
\hline 33,020 & 55 th St. Bridge & 100 & 93 & 66 & 50 & 40 & 33 & 29 & 26 & 24 & 23 \\
\hline 22,430 & Highway 42 Bridge & 97 & 52 & 38 & 29 & 24 & 20 & 17 & 15 & 13 & 12 \\
\hline \multirow[t]{2}{*}{11,850} & $15^{\text {th }}$ St. Bridge & 100 & 76 & 54 & 40 & 32 & 28 & 24 & 21 & 18 & 16 \\
\hline & $5^{\text {th }}$ St. W Bridge & 87 & 42 & 30 & 29 & 24 & 18 & 14 & 13 & 11 & 9 \\
\hline 80 & Mouth & 100 & 70 & 47 & 35 & 27 & 22 & 20 & 19 & 17 & 15 \\
\hline
\end{tabular}

A significant portion of the Outflow Channel cross section was apparently blocked by snow during the 2011 release (Fig. 43). The impact of this blockage would be to significantly increase the water stage and to significantly reduce the flow velocity in the reach immediately upstream of the blockage. This would allow the section with low velocity to collect slush ice that was carried downstream by the flow. In these slow-flowing reaches, the flow area could be blocked by slush, further increasing the upstream stages. Apparently this combination of snow blockage and ice buildup was sufficient to cause out-of-channel flooding in 2011.

\subsection{Ice transport}

Ice transport describes the ability of the channel flow to carry ice downstream. Slush ice was visible in Willow Creek during the 2013 release as soon as the IRW propagated down the channel. Changes in channel slope, sharp bends, bridge piers, islands, bars, and other obstacles to flow can significantly affect ice transport. There are few of these conditions in Willow Creek. The slush ice formed in the channel had little strength or cohesion and was easily transported downstream. However, the slush transport is sensitive to the flow velocity of the channel. As mentioned above, in 2013, the ice collected at three locations: the Ferguson Bridge; the check dam upstream of the Bifurcation; and to a lesser extent, at the Siphon. In the case of the Ferguson Bridge, a large, pre-existing depression in the channel caused a low velocity section where the slush collected. In the case of the check dam, the dam raised upstream water levels enough that the slush ice could collect in the reach immediately upstream of the dam. At 
the siphon, the slush ice collected at the upstream face of the siphon until the head had risen sufficiently to transport the slush through the siphon. Any channel obstacle, such as snow filling the channel, that impacts the flow velocity has the potential of reducing ice transport and of causing the buildup of slush ice. The buildup of slush will adversely impact upstream stages. 


\section{Recommendations for Future Wintertime Releases}

\subsection{Pre-release}

- Downstream of outfall structures, remove snow drifts that can increase upstream stages over and above the stage created by the outfall structure weir.

- Throughout the Floodway Channel, remove snow drifts that are substantially blocking the channel and could significantly increase upstream stages.

- Survey representative cross sections for snow distribution, depth, and density.

- Develop a plan for removing ice blockage from the siphon during the release. This may include pre-placement of ice clearing apparatus.

- Calibrate USGS temperature gages and install a water temperature gage at USGS gage 13058520 WILLOW CREEK FLOODWAY CHANNEL NR UCON ID.

- Determine reservoir temperature prior to release.

\subsection{Wave propagation and ice and water flow}

- Monitor release wave propagation.

- With set alarm levels, continuously monitor water level upstream of the siphon.

- Periodically monitor ice conditions at the check dam, Ferguson Bridge, Snake River, and other locations as required

- Note and record the location and time of all snow and ice blockages that significantly increase the upstream stage.

\subsection{Ice melt-out and ice-free flow}

- Monitor the advance of the ice melt-out front and the ice-free flow.

- Once the flow is ice free, discontinue monitoring unless the air temperature becomes frigid $\left(<0^{\circ} \mathrm{F}\left[-17.8^{\circ} \mathrm{C}\right]\right)$.

\subsection{Post-release}

Submit report including the following information: 
- Discharge record at USGS gages over the entire period of the release.

- Temperature record at USGS gages over the entire period of the release.

- Air temperatures over the entire period of test.

- Pre-release snow and ice conditions in the channel.

- Observations made during and after the release wave advance.

- Ririe Reservoir water temperature.

- Descriptions of the location and time of all snow and ice blockages that significantly increase the upstream stage. Include steps taken to counteract.

- Performance of the siphon under ice conditions

\subsection{General recommendations}

- Survey cross sections at representative locations of Outflow Channel, with particular attention to vertical control, to improve application of hydraulic models.

- Maintain long term record of Ririe Reservoir water temperatures.

- Investigate the impact of fall season recharge releases on the wintertime ice conditions in Willow Creek and in the Floodway Channel. 


\section{References}

Cooper, P. 2013. Personal communication. Boise, ID: Idaho Department of Water Resources.

Swenk, L. 2011. Ririe Dam 2011 USBR Controlled Winter Release February 7- 9, 2011. Power Point Presentation. Boise, ID: Idaho Department of Water Resources.

Ueda, H., P. Sellmann, and G. Abele. 1975. USA CRREL snow and ice testing equipment. Special Report 146. Hanover, NH: US Army Cold Regions Research and Engineering Laboratory.

US Department of the Interior. 2013. Ririe Project. http://www.usbr.gov/projects/Project.jsp?proj_Name=Ririe\%20Project. 


\section{Appendix A: Summary of Field Observations}

Table A1. Observations made on 10 February 2013.

\begin{tabular}{|c|c|c|c|c|c|}
\hline Time & Location Notes & HEC-RAS Location & Station (ft) & Observation & Notes \\
\hline 1420 & Ririe Dam & Ririe Dam & 119,880 & $\begin{array}{l}\text { Gates opened and initial } \\
\text { release started. }\end{array}$ & \\
\hline 1455 & $115^{\text {th }}$ St. Bridge & $\mathrm{N} 115^{\text {th }} \mathrm{E}$ & 84,480 & $\begin{array}{l}\text { No flow. Ice in channel } \\
\text { upstream of bridge. }\end{array}$ & \\
\hline 2220 & $115^{\text {th }}$ St. Bridge & $\mathrm{N} 115^{\text {th }} \mathrm{E}$ & 84,480 & $\begin{array}{l}\text { Flow reached bridge before } \\
\text { this time. }\end{array}$ & $\begin{array}{l}16^{\circ} \mathrm{F} \text { air } \\
\text { temperature. }\end{array}$ \\
\hline
\end{tabular}

Table A2. Observations made on 11 February 2013.

\begin{tabular}{|c|c|c|c|c|c|c|c|}
\hline Time & Location Notes & $\begin{array}{l}\text { HEC-RAS } \\
\text { Location }\end{array}$ & $\begin{array}{l}\text { Station } \\
\text { (ft) }\end{array}$ & Observation & Notes & $\begin{array}{c}\text { Travel } \\
\text { Time }^{*} \\
\text { (sec) }\end{array}$ & $\begin{array}{l}\text { Vel. }^{* *} \\
\text { (fps) }\end{array}$ \\
\hline 0030 & Ferguson Bridge & $\begin{array}{l}\text { Ferguson } \\
\text { Rd }\end{array}$ & 74,700 & $\begin{array}{l}\text { Release wave } \\
\text { arrived }\end{array}$ & & & \\
\hline 0710 & Bifurcation & Bifurcation & 40,900 & Dry channel & & & \\
\hline 0720 & $85^{\text {th }}$ St. Bridge & N 85th $E$ & 47,500 & Dry channel & & & \\
\hline 0730 & 95th St. Bridge & N 95th $E$ & 64,700 & Steady flow & & & \\
\hline 0735 & Ferguson Bridge & $\begin{array}{l}\text { Ferguson } \\
\text { Rd }\end{array}$ & 74,700 & Steady flow & $\begin{array}{l}\text { Hanging dam immediately } \\
\text { downstream of bridge. } \\
\text { White "hump" forming as we } \\
\text { watched. No slush visible } \\
\text { leaving hanging dam. Slush } \\
\text { arriving from upstream. }\end{array}$ & & \\
\hline 0800 & $115^{\text {th }}$ St. Bridge & $\mathrm{N} 115^{\text {th }} \mathrm{E}$ & 84,480 & Steady flow & $\begin{array}{l}\text { No slush. Dendrites growing } \\
\text { out from shore. }\end{array}$ & & \\
\hline 0910 & Bifurcation & Bifurcation & 40,900 & $\begin{array}{l}\text { Release wave } \\
\text { arrived }\end{array}$ & & & \\
\hline 0935 & $\begin{array}{l}\text { 26th St. Highway } \\
\text { Bridge }\end{array}$ & $26 / 20$ & 37,700 & $\begin{array}{l}\text { Release wave } \\
\text { arrived }\end{array}$ & & 34.32 & 2.91 \\
\hline 1002 & 55th St. Bridge & N 55th $E$ & 33,020 & $\begin{array}{l}\text { Release wave } \\
\text { arrived }\end{array}$ & & & \\
\hline 1033 & 45th St. Bridge & $N 45^{\text {th }} \mathrm{E}$ & 27,780 & $\begin{array}{l}\text { Release wave } \\
\text { arrived }\end{array}$ & & & \\
\hline 1103 & $\begin{array}{l}\text { Highway } 42 \\
\text { Bridge }\end{array}$ & YS/Rt 43 & 22,430 & $\begin{array}{l}\text { Release wave } \\
\text { arrived }\end{array}$ & & & \\
\hline 1125 & $25^{\text {th }}$ St. Bridge & N 25 th E & 17,010 & $\begin{array}{l}\text { Release wave } \\
\text { arrived }\end{array}$ & & & \\
\hline 1155 & $15^{\text {th }}$ St. Bridge & $\mathrm{N} 15^{\text {th }} \mathrm{E}$ & 11,850 & $\begin{array}{l}\text { Release wave } \\
\text { arrived }\end{array}$ & & 31.18 & 3.21 \\
\hline
\end{tabular}




\begin{tabular}{|c|c|c|c|c|c|c|c|}
\hline Time & Location Notes & $\begin{array}{l}\text { HEC-RAS } \\
\text { Location }\end{array}$ & $\begin{array}{l}\text { Station } \\
\text { (ft) }\end{array}$ & Observation & Notes & $\begin{array}{l}\text { Travel } \\
\text { Time* } \\
(\mathrm{sec})\end{array}$ & $\begin{array}{l}\text { Vel. }^{* *} \\
\text { (fps) }\end{array}$ \\
\hline 1224 & $\begin{array}{l}5^{\text {th }} \text { St. East } \\
\text { Bridge }\end{array}$ & $N 5^{\text {th }} \mathrm{E}$ & 6520 & $\begin{array}{l}\text { Release wave } \\
\text { arrived }\end{array}$ & & 35.94 & 2.78 \\
\hline 1246 & Siphon & Siphon & 3100 & $\begin{array}{l}\text { Release wave } \\
\text { arrived }\end{array}$ & $\begin{array}{l}\text { Siphon filled with slush } \\
\text { before slush was observed } \\
\text { to pass through. }\end{array}$ & & \\
\hline$?$ & Outfall structure & Outlet & 2 & & $\begin{array}{l}\text { Snow drift downstream of } \\
\text { outfall raised water level. }\end{array}$ & & \\
\hline 1500 & $45^{\text {th }}$ St. Bridge & $\mathrm{N} \mathrm{45^{ \text {th } } \mathrm { E }}$ & 27,780 & Steady flow & Slush on surface. & & \\
\hline 1515 & Ferguson Bridge & $\begin{array}{l}\text { Ferguson } \\
\mathrm{Rd}\end{array}$ & 74,700 & Steady flow & $\begin{array}{l}\text { Hanging dam and freeze up } \\
\text { jam downstream of bridge. }\end{array}$ & & \\
\hline 1530 & $115^{\text {th }}$ St. Bridge & $\mathrm{N} 115^{\text {th }} \mathrm{E}$ & 84,480 & Steady flow & $\begin{array}{l}\text { Upstream ice still in place. } \\
\text { Single crack down center of } \\
\text { channel with flooded edges } \\
\text { along shore. }\end{array}$ & & \\
\hline 1620 & Bifurcation & Bifurcation & 40,900 & Steady flow. & $\begin{array}{l}\text { Slush cover } 10 \% \text { to } 15 \% \text { of } \\
\text { surface. }\end{array}$ & & \\
\hline
\end{tabular}

${ }^{*}$ Time for object floating at surface to travel $100 \mathrm{ft}$.

**Estimated surface velocity.

Table A3. Observations made on 12 February 2013.

\begin{tabular}{|c|c|c|c|c|c|c|c|}
\hline Time & Location Notes & $\begin{array}{l}\text { HEC-RAS } \\
\text { Location }\end{array}$ & $\begin{array}{l}\text { Station } \\
\text { (ft) }\end{array}$ & Observation & Notes & $\begin{array}{l}\text { Travel } \\
\text { Time* } \\
\text { (sec) }\end{array}$ & $\begin{array}{l}\text { Vel. }^{* *} \\
\text { (fps) }\end{array}$ \\
\hline 0715 & $115^{\text {th }}$ St. Bridge & $\mathrm{N} 115^{\text {th }} \mathrm{E}$ & 84,480 & Steady flow & $\begin{array}{l}\text { Ice cover upstream still in } \\
\text { place. Outer } 1 / 3 \text { of ice } \\
\text { cover flooded. Water } \\
\text { turbid. }\end{array}$ & & \\
\hline 0739 & Ferguson Bridge & $\begin{array}{l}\text { Ferguson } \\
\text { Rd }\end{array}$ & 74,700 & Steady flow & $\begin{array}{l}\text { Slush on surface. Hanging } \\
\text { dam in place. Ice floes } \\
\text { going under and out of } \\
\text { hanging dam. Water } \\
\text { turbid. }\end{array}$ & & \\
\hline 0754 & Bifurcation & Bifurcation & 40,900 & Steady flow & $\begin{array}{l}\text { Some slush on surface. } \\
\text { Water turbid. }\end{array}$ & & \\
\hline 0806 & $\begin{array}{l}\text { Check dam u/s } \\
\text { Bifurcation }\end{array}$ & $\begin{array}{l}\text { Rock } \\
\text { Check } \\
\text { Dam }\end{array}$ & 44,590 & $\begin{array}{l}\text { Ice cover in } \\
\text { place } \\
\text { upstream of } \\
\text { check dam }\end{array}$ & $\begin{array}{l}\text { Check dam located } 0.4 \\
\text { miles upstream of } \\
\text { bifurcation. }\end{array}$ & & \\
\hline 0825 & $\begin{array}{l}\text { Control } \\
\text { Structure }\end{array}$ & $\begin{array}{l}\text { Willow } \\
\text { Creek } \\
\text { Structure }\end{array}$ & 36,180 & Steady flow & $\begin{array}{l}\text { Small amount of slush. } \\
\text { Water turbid. }\end{array}$ & & \\
\hline 0838 & $45^{\text {th }}$ St. Bridge & $N 45^{\text {th }} \mathrm{E}$ & 27,780 & Steady flow & $\begin{array}{l}\text { Small amount of slush. } \\
\text { Water turbid. }\end{array}$ & & \\
\hline
\end{tabular}




\begin{tabular}{|c|c|c|c|c|c|c|c|}
\hline Time & Location Notes & $\begin{array}{l}\text { HEC-RAS } \\
\text { Location }\end{array}$ & $\begin{array}{l}\text { Station } \\
\text { (ft) }\end{array}$ & Observation & Notes & $\begin{array}{l}\text { Travel } \\
\text { Time* } \\
\text { (sec) }\end{array}$ & $\begin{array}{l}\text { Vel. }^{* *} \\
\text { (fps) }\end{array}$ \\
\hline 0903 & $15^{\text {th }}$ St. Bridge & $\mathrm{N} 15^{\text {th }} \mathrm{E}$ & 11,850 & Steady flow & Water turbid & 12.89 & 7.76 \\
\hline 0911 & $\begin{array}{l}5^{\text {th }} \text { St. East } \\
\text { Bridge }\end{array}$ & $N 5^{\text {th }} E$ & 6520 & Steady flow & Slush on surface. & 16.97 & 5.89 \\
\hline 0920 & Siphon & Siphon & 3100 & Steady flow & $\begin{array}{l}\text { Some slush on surface. } \\
\text { Water turbid. }\end{array}$ & 14.36 & 6.96 \\
\hline 0930 & Outfall structure & Outlet & 2 & Steady flow & $\begin{array}{l}\text { Some slush on surface. } \\
\text { Water turbid. Water has } \\
\text { found route through Snake } \\
\text { River ice cover. Snake } \\
\text { River ice cover discolored } \\
\text { downstream. }\end{array}$ & & \\
\hline 1043 & $115^{\text {th }}$ St. Bridge & $\mathrm{N} 115^{\text {th }} \mathrm{E}$ & 84,480 & Steady flow & $\begin{array}{l}\text { No slush. } 21^{\circ} \mathrm{F} \text { air } \\
\text { temperature. }\end{array}$ & & \\
\hline 1135 & $115^{\text {th }}$ St. Bridge & $\mathrm{N} 115^{\text {th }} \mathrm{E}$ & 84,480 & Steady flow & $\begin{array}{l}\text { Melt-out of ice cover } \\
\text { observed. All ice gone from } \\
\text { about } 1 / 2 \text { mile upstream of } \\
\text { bridge. }\end{array}$ & & \\
\hline 1255 & Ferguson Bridge & $\begin{array}{l}\text { Ferguson } \\
\text { Rd }\end{array}$ & 74,700 & Steady flow & $\begin{array}{l}\text { Leading edge of hanging } \\
\text { dam worn away. Upstream } \\
\text { stage dropped } 12-18 \text { in. } \\
\text { By } 1345 \text {, hanging dam } \\
\text { broken up and largely } \\
\text { transported downstream. }\end{array}$ & & \\
\hline 1347 & 95th St. Bridge & $\mathrm{N} \mathrm{95^{ \text {th } } \mathrm { E }}$ & 64,700 & Steady flow & $\begin{array}{l}\text { Ice from broken up } \\
\text { hanging dam. } 10 \% \text { of } \\
\text { surface covered by ice }\end{array}$ & & \\
\hline 1402 & 85th St. Bridge & $N 85^{\text {th }} \mathrm{E}$ & 47,500 & Steady flow & $\begin{array}{l}\text { Moderate amount of ice } \\
\text { coming downstream. Snow } \\
\text { on right bank under water } \\
\text { immediately downstream } \\
\text { of bridge. }\end{array}$ & & \\
\hline 1422 & $\begin{array}{l}\text { Check dam u/s } \\
\text { Bifurcation }\end{array}$ & $\begin{array}{l}\text { Rock } \\
\text { Check } \\
\text { Dam }\end{array}$ & 44,590 & Steady flow & $\begin{array}{l}\text { Slush coming downstream. } \\
\text { Ice jam remains in place. } \\
\text { Slush passing through. }\end{array}$ & & \\
\hline 1512 & Outfall structure & Outlet & 2 & Steady flow & $\begin{array}{l}\text { Flow going directly through } \\
\text { Snake River ice cover. }\end{array}$ & & \\
\hline
\end{tabular}

*Time for object floating at surface to travel $100 \mathrm{ft}$.

**Estimated surface velocity. 


\section{Appendix B: Summary of Ice Observations}

\begin{tabular}{|c|c|c|c|c|c|}
\hline \multicolumn{6}{|c|}{$115^{\text {th }}$ St. Bridge } \\
\hline Date & Time & Location & $\begin{array}{l}\% \text { Ice } \\
\text { Cover }\end{array}$ & Description & Source \\
\hline $2 / 11 / 2013$ & 1530 & $\begin{array}{l}\text { u/s bend } \\
\text { above cable } \\
\text { bridge }\end{array}$ & 80 & $\begin{array}{l}\text { Upstream ice still in place. Single crack down center } \\
\text { of channel with flooded edges along shore. }\end{array}$ & Daly \\
\hline $2 / 11 / 2013$ & 1549 & $\begin{array}{l}\text { u/s bend } \\
\text { above cable } \\
\text { bridge }\end{array}$ & 85 & $\begin{array}{l}\text { Solid ice cover with crack along centerline. Some } \\
\text { flow and melt-out along banks. }\end{array}$ & Carr \\
\hline $2 / 12 / 2013$ & 715 & $\begin{array}{l}\mathrm{u} / \mathrm{s} \text { bend } \\
\text { above cable } \\
\text { bridge }\end{array}$ & 60 & $\begin{array}{l}\text { Ice cover upstream still in place. Outer } 1 / 3 \text { of ice } \\
\text { cover flooded. Water turbid. }\end{array}$ & Daly \\
\hline $2 / 12 / 2013$ & 916 & $\begin{array}{l}\text { u/s bend } \\
\text { above cable } \\
\text { bridge }\end{array}$ & 60 & $\begin{array}{l}\text { Solid ice cover with crack along centerline. Thinning } \\
\text { along banks. More flow and melt-out along banks. }\end{array}$ & Carr \\
\hline $2 / 12 / 2013$ & 929 & $\begin{array}{l}\text { u/s bend } \\
\text { above cable } \\
\text { bridge }\end{array}$ & 50 & Ice along centerline with crack. & Cooper \\
\hline $2 / 12 / 2013$ & 1117 & $\begin{array}{l}\text { u/s bend } \\
\text { above cable } \\
\text { bridge }\end{array}$ & 50 & $\begin{array}{l}\text { Solid ice cover with one or two cracks along center. } \\
\text { More transparent }\end{array}$ & Carr \\
\hline $2 / 12 / 2013$ & 1121 & $\begin{array}{l}\text { u/s bend } \\
\text { above cable } \\
\text { bridge }\end{array}$ & 0 & Cover released in large floes. Moved downstream. & Carr \\
\hline $2 / 12 / 2013$ & 1135 & $\begin{array}{l}\text { u/s bend } \\
\text { above cable } \\
\text { bridge }\end{array}$ & 0 & $\begin{array}{l}\text { Melt-out of ice cover observed. All ice gone from } \\
\text { about } 1 / 2 \text { mile upstream of bridge. }\end{array}$ & Daly \\
\hline $2 / 11 / 2013$ & 1543 & $\begin{array}{l}\mathrm{u} / \mathrm{s} \text { at ditch } \\
\text { confluence }\end{array}$ & 70 & Solid ice along center of channel. & Carr \\
\hline $2 / 12 / 2013$ & 716 & $\begin{array}{l}\mathrm{u} / \mathrm{s} \text { at ditch } \\
\text { confluence }\end{array}$ & 70 & $\begin{array}{l}\text { Solid ice along center of channel with streamwise } \\
\text { crack. Flow along bank. }\end{array}$ & Carr \\
\hline $2 / 12 / 2013$ & 1241 & $\begin{array}{l}\text { u/s at ditch } \\
\text { confluence }\end{array}$ & 35 & Long free floes, paired along old central crack. & Carr \\
\hline $2 / 11 / 2013$ & 1544 & $\begin{array}{l}\mathrm{u} / \mathrm{s} \text { at cable } \\
\text { bridge }\end{array}$ & 90 & Solid ice cover with some flow along banks. & Carr \\
\hline $2 / 11 / 2013$ & 1546 & $\begin{array}{l}\mathrm{u} / \mathrm{s} \text { at cable } \\
\text { bridge }\end{array}$ & 80 & Cracked ice cover down center. Flow along banks. & Carr \\
\hline $2 / 10 / 2013$ & 1455 & $\begin{array}{l}\mathrm{u} / \mathrm{s} \text { at cable } \\
\text { bridge }\end{array}$ & 100 & Ice in channel upstream of bridge. & Daly \\
\hline $2 / 11 / 2013$ & 800 & $u / s$ & 0 & No slush. Dendrites growing out from shore. & Daly \\
\hline $2 / 11 / 2013$ & 1138 & $\mathrm{u} / \mathrm{s}$ & 0 & No slush. & Cooper \\
\hline $2 / 11 / 2013$ & 1611 & $u / s$ & 10 & Little shore ice. & Carr \\
\hline
\end{tabular}




\begin{tabular}{|c|l|l|r|l|l|}
\hline \multicolumn{7}{|c|}{ Date } & \multicolumn{1}{|c|}{ Time } & Location & $\begin{array}{r}\text { \% Ice } \\
\text { Cover }\end{array}$ & \multicolumn{1}{l|}{ Description } & Source \\
\hline $2 / 12 / 2013$ & 733 & u/s & 0 & Open water. & Carr \\
\hline $2 / 12 / 2013$ & 1036 & u/s & 0 & No slush. & Cooper \\
\hline $2 / 12 / 2013$ & 1043 & u/s & 0 & No slush. 21 ${ }^{\circ} \mathrm{F}$ air temperature. & Daly \\
\hline $2 / 12 / 2013$ & 1110 & u/s & 0 & No slush. & Cooper \\
\hline $2 / 12 / 2013$ & 1230 & u/s & 40 & Large free floes, about stream width in long & Carr \\
& & & 0 & No slush. & Cooper \\
\hline $2 / 13 / 2013$ & 945 & u/s & 0 & No ice/slush. & Cooper \\
\hline $2 / 15 / 2013$ & 2031 & u/s & 0 & No slush. & Cooper \\
\hline $2 / 11 / 2013$ & 1138 & d/s & 0 & No slush. & Cooper \\
\hline $2 / 12 / 2013$ & 1036 & d/s & 5 & Minor ice floes. & Cooper \\
\hline $2 / 12 / 2013$ & 1236 & d/s & 0 & No slush. & Cooper \\
\hline $2 / 12 / 2013$ & 1245 & d/s & 0 & No slush. & Cooper \\
\hline $2 / 13 / 2013$ & 945 & d/s & 0 & No ice/slush. & Cooper \\
\hline $2 / 15 / 2013$ & 2031 & d/s & & &
\end{tabular}

\begin{tabular}{|c|c|c|c|c|c|}
\hline \multicolumn{6}{|c|}{ Ferguson Bridge } \\
\hline Date & Time & Location & $\begin{array}{l}\% \text { Ice } \\
\text { Cover }\end{array}$ & Description & Source \\
\hline $2 / 10 / 2013$ & 2225 & $u / s$ & 5 & Ice floes and water begin to arrive. & Carr \\
\hline $2 / 11 / 2013$ & 1121 & $u / s$ & 10 & New shore ice. & Cooper \\
\hline $2 / 11 / 2013$ & 1441 & $\mathrm{u} / \mathrm{s}$ & 10 & Shore ice. & Cooper \\
\hline $2 / 11 / 2013$ & 1523 & $u / s$ & 15 & Shore ice on right bank, slush. & Carr \\
\hline $2 / 12 / 2013$ & 744 & $u / s$ & 20 & $\begin{array}{l}\text { Shore ice extended out from right bank around bend, } \\
\text { slush. }\end{array}$ & Carr \\
\hline $2 / 12 / 2013$ & 913 & $\mathrm{u} / \mathrm{s}$ & 15 & Shore ice, minor slush along thalweg. & Cooper \\
\hline $2 / 12 / 2013$ & 1248 & $\mathrm{u} / \mathrm{s}$ & 5 & Almost no shore ice; almost no slush. & Cooper \\
\hline $2 / 13 / 2013$ & 935 & $u / s$ & 0 & No ice. & Cooper \\
\hline $2 / 15 / 2013$ & 2036 & $u / s$ & 0 & Shore ice, bits of slush. & Cooper \\
\hline $2 / 11 / 2013$ & 735 & $d / s$ & 80 & $\begin{array}{l}\text { Hanging dam immediately downstream of bridge. White } \\
\text { "hump" forming as we watched. No slush visible leaving } \\
\text { hanging dam. Slush arriving from upstream. }\end{array}$ & Daly \\
\hline $2 / 11 / 2013$ & 1122 & $d / s$ & 80 & Hanging dam. & Cooper \\
\hline $2 / 11 / 2013$ & 1442 & $d / s$ & 85 & Hanging dam. & Cooper \\
\hline $2 / 11 / 2013$ & 1515 & $d / s$ & 90 & Hanging dam and freeze-up jam downstream of bridge. & Daly \\
\hline $2 / 11 / 2013$ & 1523 & $d / s$ & 90 & $\begin{array}{l}\text { Hanging dam, some flow around left bank, and open } \\
\text { water just under bridge. }\end{array}$ & Carr \\
\hline $2 / 12 / 2013$ & 739 & $d / s$ & 0 & $\begin{array}{l}\text { Slush on surface. Hanging dam in place. Ice floes going } \\
\text { under and out of hanging dam. Water turbid. }\end{array}$ & Daly \\
\hline $2 / 12 / 2013$ & 743 & $d / s$ & 100 & Hanging dam. & Carr \\
\hline
\end{tabular}




\begin{tabular}{|c|c|c|c|c|c|}
\hline \multicolumn{6}{|c|}{ Ferguson Bridge } \\
\hline Date & Time & Location & $\begin{array}{l}\% \text { Ice } \\
\text { Cover }\end{array}$ & Description & Source \\
\hline $2 / 12 / 2013$ & 913 & $d / s$ & 100 & Hanging dam. & Cooper \\
\hline $2 / 12 / 2013$ & 1245 & $d / s$ & 75 & Hanging dam, broken up at u/s end. & Cooper \\
\hline $2 / 12 / 2013$ & 1255 & $d / s$ & 75 & $\begin{array}{l}\text { Leading edge of hanging dam worn away }(1245) \text {. } \\
\text { Upstream stage dropped } 12-18 \text { in. By } 1345 \text {, hanging } \\
\text { dam broken up and largely transported downstream. }\end{array}$ & Daly \\
\hline $2 / 12 / 2013$ & 1259 & $d / s$ & 75 & Hanging dam, broken up at u/s end. & Carr \\
\hline $2 / 12 / 2013$ & 1313 & $d / s$ & 70 & Hanging dam, broken up at $\mathrm{u} / \mathrm{s}$ end. & Cooper \\
\hline $2 / 12 / 2013$ & 1320 & $d / s$ & 65 & Hanging dam, broken up at u/s end. & Cooper \\
\hline $2 / 12 / 2013$ & 1327 & $d / s$ & 60 & $\begin{array}{l}\text { Hanging dam, broken up at } \mathrm{u} / \mathrm{s} \text { end, flow around right } \\
\text { bank. }\end{array}$ & Cooper \\
\hline $2 / 12 / 2013$ & 1328 & $d / s$ & 50 & Hanging dam breaking up; solid circle visible. & Carr \\
\hline $2 / 12 / 2013$ & 1332 & $d / s$ & 60 & $\begin{array}{l}\text { Hanging dam, broken up at } \mathrm{u} / \mathrm{s} \text { end, flow around left } \\
\text { bank, mid-size flows arriving from upstream, going } \\
\text { under cover. }\end{array}$ & Cooper \\
\hline $2 / 12 / 2013$ & 1342 & $d / s$ & 20 & Hanging dam broken up all but at toe of jam. & Cooper \\
\hline $2 / 13 / 2013$ & 938 & $d / s$ & 0 & No ice. & Cooper \\
\hline
\end{tabular}

\begin{tabular}{|c|c|l|c|l|l|}
\hline \multicolumn{7}{|c|}{$95^{\text {th }}$ St. Bridge } & \multicolumn{1}{c|}{ Description } & Source \\
\hline Date & Time & Location & $\begin{array}{c}\text { \% Ice } \\
\text { Cover }\end{array}$ & \multicolumn{1}{|c|}{ Cooper } \\
\hline $2 / 11 / 2013$ & 1402 & u/s & 10 & Shore ice, slush along thalweg. & Daly \\
\hline $2 / 12 / 2013$ & 1347 & u/s & 10 & $\begin{array}{l}\text { Ice from broken up hanging dam. 10\% of surface } \\
\text { covered by ice. }\end{array}$ & \\
\hline
\end{tabular}

\begin{tabular}{|c|c|c|c|c|c|}
\hline \multicolumn{6}{|c|}{ 85th St Bridge } \\
\hline Date & Time & Location & $\begin{array}{l}\% \text { Ice } \\
\text { Cover }\end{array}$ & Description & Source \\
\hline $2 / 11 / 2013$ & 746 & $u / s$ & 0 & Flow arrives. & Carr \\
\hline $2 / 11 / 2013$ & 1108 & $u / s$ & 5 & $\begin{array}{l}\text { A small amount of slush moving d/s on right, submerged } \\
\text { snowbank on left, eddy causing upstream flow upstream } \\
\text { of snowbank. }\end{array}$ & Cooper \\
\hline $2 / 12 / 2013$ & 1402 & $\mathrm{u} / \mathrm{s}$ & 20 & $\begin{array}{l}\text { Some medium sized floes moving downstream along left } \\
\text { bank. }\end{array}$ & Carr \\
\hline $2 / 12 / 2013$ & 1402 & $u / s$ & 20 & $\begin{array}{l}\text { Moderate amount of ice coming downstream. Snow on } \\
\text { right bank under water immediately downstream of } \\
\text { bridge. }\end{array}$ & Daly \\
\hline
\end{tabular}




\begin{tabular}{|c|l|l|c|l|l|}
\hline \multicolumn{7}{|c|}{ Rock Check Dam above Bifurcation } & \multicolumn{1}{c|}{ Description } \\
\hline Date & Time & Location & $\begin{array}{c}\text { \% Ice } \\
\text { Cover }\end{array}$ & \multicolumn{1}{c|}{ Source } \\
\hline $2 / 12 / 2013$ & 806 & u/s & 85 & Ice cover in place upstream of check dam. & Daly \\
\hline $2 / 12 / 2013$ & 810 & u/s & 85 & Snow/ice/slush piled up upstream of dam. & Carr \\
\hline $2 / 12 / 2013$ & 1214 & u/s & 80 & Snow/ice/slush piled up upstream of dam. & Carr \\
\hline $2 / 12 / 2013$ & 1356 & u/s & 80 & Snow/ice/slush piled up upstream of dam. & Cooper \\
\hline $2 / 12 / 2013$ & 1422 & u/s & 80 & $\begin{array}{l}\text { Slush coming downstream. Ice jam remains in place. } \\
\text { Slush passing through. }\end{array}$ & Daly \\
\hline
\end{tabular}

\begin{tabular}{|c|c|c|c|c|c|}
\hline \multicolumn{6}{|c|}{ Bifurcation } \\
\hline Date & Time & Location & $\begin{array}{l}\text { \% Ice } \\
\text { Cover }\end{array}$ & Description & Source \\
\hline $2 / 11 / 2013$ & 910 & $\mathrm{u} / \mathrm{s}$ & 0 & Release wave arrived. & Daly \\
\hline $2 / 11 / 2013$ & 924 & $\mathrm{u} / \mathrm{s}$ & 5 & Very little slush. & Carr \\
\hline $2 / 11 / 2013$ & 1507 & $u / s$ & 45 & Heavy slush. & Cooper \\
\hline $2 / 11 / 2013$ & 1620 & $u / s$ & 15 & Slush cover $10 \%$ to $15 \%$ of surface. & Daly \\
\hline $2 / 12 / 2013$ & 754 & $\mathrm{u} / \mathrm{s}$ & 5 & Some slush on surface. Water turbid. & Daly \\
\hline $2 / 12 / 2013$ & 759 & $\mathrm{u} / \mathrm{s}$ & 10 & Shore ice on left bank, small amount of slush. & Carr \\
\hline $2 / 12 / 2013$ & 1208 & $\mathrm{u} / \mathrm{s}$ & 35 & $\begin{array}{l}\text { Shore ice on left bank, further into flow, small amount of } \\
\text { slush. }\end{array}$ & Carr \\
\hline $2 / 12 / 2013$ & 1420 & $\mathrm{u} / \mathrm{s}$ & 30 & Shore ice on left bank, slush. & Cooper \\
\hline $2 / 13 / 2013$ & 926 & $\mathrm{u} / \mathrm{s}$ & 0 & No slush. & Cooper \\
\hline $2 / 12 / 2013$ & 1208 & $d / s$ & 50 & Submerged snow, anchor ice. & Carr \\
\hline $2 / 12 / 2013$ & 1420 & $d / s$ & 15 & Slush. & Cooper \\
\hline $2 / 13 / 2013$ & 926 & $d / s$ & 0 & No slush. & Cooper \\
\hline
\end{tabular}

\begin{tabular}{|c|l|l|c|l|l|}
\hline \multicolumn{7}{|c|}{ Willow Creek Control Structure } & \multicolumn{1}{c|}{ Description } \\
\hline Date & Time & Location & $\begin{array}{c}\text { \% Ice } \\
\text { Cover }\end{array}$ & \multicolumn{1}{|c|}{ Source } \\
\hline $2 / 11 / 2013$ & 1109 & u/s & 0 & No slush, no flow. & Carr \\
\hline $2 / 12 / 2013$ & 825 & u/s & 5 & Small amount of slush. Water turbid. & Daly \\
\hline $2 / 12 / 2013$ & 831 & d/s & 0 & No slush. & Carr \\
\hline
\end{tabular}




\begin{tabular}{|c|l|l|r|l|l|}
\hline \multicolumn{2}{|c|}{$5^{\text {th }}$ St Bridge } & \multicolumn{1}{c|}{ Description } \\
\hline Date & Time & Location & $\begin{array}{c}\text { \% Ice } \\
\text { Cover }\end{array}$ & \multicolumn{1}{c|}{ Source } \\
\hline $2 / 11 / 2013$ & 1002 & u/s & 0 & Release wave arrived. & Daly \\
\hline $2 / 12 / 2013$ & 1428 & u/s & 10 & Small amounts of slush. & Cooper \\
\hline $2 / 12 / 2013$ & 1427 & d/s & 5 & Small amounts of slush. & Cooper \\
\hline
\end{tabular}

\begin{tabular}{|c|l|l|r|l|l|}
\hline \multicolumn{2}{|c|}{ Date } & Time & Location & $\begin{array}{r}\text { \% Ice } \\
\text { Cover }\end{array}$ & \multicolumn{1}{c|}{ Description } \\
\hline $2 / 11 / 2013$ & 1033 & u/s & 0 & Release wave arrived. & Source \\
\hline $2 / 11 / 2013$ & 1038 & u/s & 20 & Medium slush, eddy on right bank. & Daly \\
\hline $2 / 11 / 2013$ & 1041 & u/s & 40 & Heavy slush. & Carr \\
\hline $2 / 11 / 2013$ & 1500 & u/s & 20 & Slush on surface. & Cooper \\
\hline $2 / 12 / 2013$ & 838 & u/s & 10 & Small amount of slush. Water turbid. & Daly \\
\hline $2 / 12 / 2013$ & 841 & u/s & 5 & Almost no slush. & Daly \\
\hline $2 / 12 / 2013$ & 1431 & u/s & 5 & Minimal slush. & Carr \\
\hline $2 / 11 / 2013$ & 1040 & u/s & 30 & Heavy slush, some small floes. & Cooper \\
\hline $2 / 11 / 2013$ & 1508 & d/s & 20 & Rafted slush. & Carr \\
\hline
\end{tabular}

\begin{tabular}{|c|c|c|c|c|c|}
\hline \multicolumn{6}{|c|}{$35^{\text {th }}$ St Bridge } \\
\hline Date & Time & Location & $\begin{array}{l}\% \text { Ice } \\
\text { Cover }\end{array}$ & Description & Source \\
\hline $2 / 11 / 2013$ & 1103 & $d / s$ & 0 & Release wave arrived. & Carr \\
\hline $2 / 12 / 2013$ & 1441 & $d / s$ & 10 & Small submerged floes. & Cooper \\
\hline
\end{tabular}

\begin{tabular}{|c|c|c|c|c|c|}
\hline \multicolumn{6}{|c|}{$25^{\text {th }}$ St Bridge } \\
\hline Date & Time & Location & $\begin{array}{l}\text { \% Ice } \\
\text { Cover }\end{array}$ & Description & Source \\
\hline $2 / 11 / 2013$ & 1125 & $\mathrm{u} / \mathrm{s}$ & 0 & Release wave arrived. & Daly \\
\hline $2 / 11 / 2013$ & 1137 & $\mathrm{u} / \mathrm{s}$ & 80 & Heavy slush. & Carr \\
\hline $2 / 11 / 2013$ & 1200 & $\mathrm{u} / \mathrm{s}$ & 70 & Heavy slush. & Cooper \\
\hline $2 / 12 / 2013$ & 1449 & $\mathrm{u} / \mathrm{s}$ & 50 & Shore ice near bridge; medium size submerged floes. & Cooper \\
\hline $2 / 11 / 2013$ & 1200 & $d / s$ & 60 & Heavy slush, smaller pieces than upstream. & Cooper \\
\hline $2 / 11 / 2013$ & 1415 & $d / s$ & 40 & $\begin{array}{l}\text { Smaller slush, shore ice at level slightly above water } \\
\text { surface. }\end{array}$ & Cooper \\
\hline
\end{tabular}




\begin{tabular}{|c|c|c|c|c|c|}
\hline \multicolumn{6}{|c|}{$15^{\text {th }}$ St Bridge } \\
\hline Date & Time & Location & $\begin{array}{l}\% \text { Ice } \\
\text { Cover }\end{array}$ & Description & Source \\
\hline $2 / 11 / 2013$ & 1155 & $u / s$ & 0 & Release wave arrived. & Daly \\
\hline $2 / 11 / 2013$ & 1205 & $\mathrm{u} / \mathrm{s}$ & 90 & Heavy slush, building up in eddies on $\mathrm{u} / \mathrm{s}$ side of bridge. & Cooper \\
\hline $2 / 12 / 2013$ & 903 & $\mathrm{u} / \mathrm{s}$ & 0 & Water turbid. & Daly \\
\hline $2 / 11 / 2013$ & 1201 & $d / s$ & 70 & Heavy slush. & Carr \\
\hline
\end{tabular}

\begin{tabular}{|c|c|c|c|c|c|}
\hline \multicolumn{6}{|c|}{$5^{\text {th }}$ St Bridge } \\
\hline Date & Time & Location & $\begin{array}{l}\% \text { Ice } \\
\text { Cover }\end{array}$ & Description & Source \\
\hline $2 / 11 / 2013$ & 1224 & $u / s$ & 0 & Release wave arrived. & Daly \\
\hline $2 / 11 / 2013$ & 1456 & $u / s$ & 30 & Slush chunks. & Cooper \\
\hline $2 / 12 / 2013$ & 911 & $u / s$ & 10 & Slush on surface. & Daly \\
\hline $2 / 12 / 2013$ & 914 & $u / s$ & 5 & $\begin{array}{l}\text { Almost no slush; still somewhat submerged snowbank } \\
\text { on left. }\end{array}$ & Carr \\
\hline
\end{tabular}

\begin{tabular}{|c|l|l|r|l|l|}
\hline \multicolumn{2}{|c|}{ Date } & Time & Location & $\begin{array}{c}\text { \% Ice } \\
\text { Cover }\end{array}$ & \multicolumn{1}{c|}{ Description } \\
\hline $2 / 11 / 2013$ & 1246 & u/s & 80 & $\begin{array}{l}\text { Siphon filled with slush before slush was observed to } \\
\text { pass through. }\end{array}$ & Daly \\
\hline $2 / 11 / 2013$ & 1252 & u/s & 80 & Incoming large pieces of slush jamming. & Carr \\
\hline $2 / 11 / 2013$ & 1255 & u/s & 85 & Jammed slush. & Cooper \\
\hline $2 / 11 / 2013$ & 1350 & u/s & 65 & $\begin{array}{l}\text { Shore ice/old jam coming in from both banks; slush } \\
\text { moving through small channel. }\end{array}$ & Cooper \\
\hline $2 / 11 / 2013$ & 1530 & u/s & 45 & Old jam almost gone; large slush. & Cooper \\
\hline $2 / 11 / 2013$ & 1709 & u/s & 50 & Jammed slush, parts submerged, slug from upstream. & Carr \\
\hline $2 / 11 / 2013$ & 1710 & u/s & 50 & Upstream water level has dropped slightly. & Daly \\
\hline $2 / 12 / 2013$ & 920 & u/s & 5 & Some slush on surface. Water turbid. & Daly \\
\hline $2 / 12 / 2013$ & 922 & u/s & 5 & Little bits of submerged slush. & Carr \\
\hline $2 / 12 / 2013$ & 1505 & u/s & 20 & Large chunks of submerged slush. & Carr \\
\hline
\end{tabular}

\begin{tabular}{|c|l|l|r|l|l|}
\hline \multicolumn{7}{|c|}{ Mouth of Outflow Channel } & Sescription \\
\hline Date & Time & Location & $\begin{array}{r}\text { \% Ice } \\
\text { Cover }\end{array}$ & \multicolumn{1}{c|}{ Source } \\
\hline $2 / 12 / 2013$ & 931 & u/s & 25 & Slush. & Carr \\
\hline $2 / 11 / 2013$ & 1247 & u/s & 0 & Flow arrival. & Carr \\
\hline $2 / 11 / 2013$ & 1312 & u/s & 10 & Small amount of slush. & Cooper \\
\hline
\end{tabular}




\begin{tabular}{|c|l|l|r|l|l|}
\hline \multicolumn{7}{|c|}{ Date } & Time & Location & $\begin{array}{r}\text { \% Ice } \\
\text { Cover }\end{array}$ & \multicolumn{1}{c|}{ Description } & Source \\
\hline $2 / 11 / 2013$ & 1318 & u/s & 15 & Slush. & Carr \\
\hline $2 / 11 / 2013$ & 1338 & u/s & 80 & Heavy slush. & Cooper \\
\hline $2 / 12 / 2013$ & 831 & u/s & 30 & Slush, minor shore ice. & Cooper \\
\hline $2 / 12 / 2013$ & 1503 & u/s & 50 & llush rafts. & Cooper \\
\hline $2 / 12 / 2013$ & 1515 & u/s & 35 & llush. & Carr \\
\hline $2 / 13 / 2013$ & 854 & u/s & 0 & No slush. & Cooper \\
\hline $2 / 11 / 2013$ & 1310 & weir & 0 & Flow arrival. & Carr \\
\hline $2 / 11 / 2013$ & 1316 & weir & 5 & Small amount of slush. & Carr \\
\hline $2 / 11 / 2013$ & 1323 & weir & 80 & Heavy slush compacted together. & Carr \\
\hline $2 / 11 / 2013$ & 1727 & weir & 30 & Slush. & Carr \\
\hline $2 / 12 / 2013$ & 930 & weir & 35 & $\begin{array}{l}\text { Some slush on surface. Water turbid. Water has found } \\
\text { route through Snake River ice cover. Snake River ice } \\
\text { cover discolored downstream. }\end{array}$ & Daly \\
\hline $2 / 12 / 2013$ & 931 & weir & 35 & Submerged slush. & Carr \\
\hline $2 / 12 / 2013$ & 1512 & weir & 25 & Flow going directly through Snake River ice cover. & Daly \\
\hline
\end{tabular}




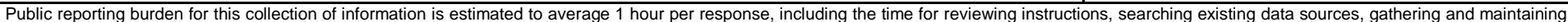

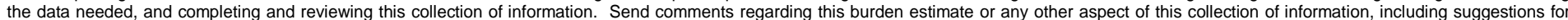

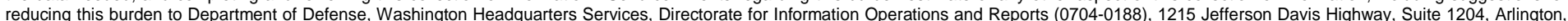

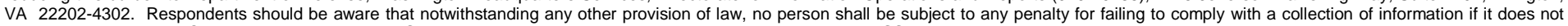
display a currently valid OMB control number. PLEASE DO NOT RETURN YOUR FORM TO THE ABOVE ADDRESS.

\begin{tabular}{l|l}
$\begin{array}{l}\text { 1. REPORT DATE }(D D-M M-Y Y Y Y) \\
\text { June } 2013\end{array}$ & $\begin{array}{l}\text { 2. REPORT TYPE } \\
\text { Technical Report/Final }\end{array}$ \\
\hline
\end{tabular}

4. TITLE AND SUBTITLE

Ririe Dam Release Test Assessment

3. DATES COVERED (From - To)

5a. CONTRACT NUMBER

5b. GRANT NUMBER

5c. PROGRAM ELEMENT NUMBER

6. AUTHOR(S)

5d. PROJECT NUMBER

Steven F. Daly, Meredith Carr, Stephen Hall, and Jeremy Giovando

5e. TASK NUMBER

5f. WORK UNIT NUMBER

7. PERFORMING ORGANIZATION NAME(S) AND ADDRESS(ES)

8. PERFORMING ORGANIZATION REPORT

Cold Regions Research and Engineering Laboratory (CRREL)

US Army Engineer Research and Development Center NUMBER

72 Lyme Road Hanover, NH 03755-1290

ERDC/CRREL TR-13-10

9. SPONSORING I MONITORING AGENCY NAME(S) AND ADDRESS(ES)

10. SPONSOR/MONITOR'S ACRONYM(S)

11. SPONSOR/MONITOR'S REPORT NUMBER(S)

\section{DISTRIBUTION / AVAILABILITY STATEMENT}

Approved for public release; distribution is unlimited.

\section{SUPPLEMENTARY NOTES}

\section{ABSTRACT}

To potentially increase storage over the winter season, the US Army Corps of Engineers (Corps) Walla Walla District (NWW) is currently evaluating flood control operations at Ririe Reservoir. Because there is little experience with winter releases and a previous winter release resulted in minor flooding, it is important to understand the potential problems associated with releases in these conditions. Therefore, the Corps conducted a Release Test on 10-13 February 2013. Throughout the test, instruments took detailed measurements of the water temperature, stage, and discharge along the Willow Creek channel; and personnel observed the dynamic ice conditions.

The test included an initial release of $150 \mathrm{cfs}$ for $28 \mathrm{hr}$; a rapid increase to $300 \mathrm{cfs}$, which was held for $14.5 \mathrm{hr}$; and another rapid increase to $500 \mathrm{cfs}$, which was held for $24 \mathrm{hr}$. The flow was then shut off. Neither the Initial Release Wave nor subsequent flow significantly removed, dislodged, or eroded snow in the channel; the snow melted only after a thermal melt-out front advanced downstream. No out-of-bank flooding occurred.

As a result of the information gathered from this Release Test and from one in 2011, this report presents a series of recommendations for future wintertime releases.

\begin{tabular}{|ll}
\hline 15. SUBJECT TERMS & Melt-out \\
Flooding & Slush \\
Ice & Snow \\
\hline
\end{tabular}

16. SECURITY CLASSIFICATION OF:

a. REPORT

$\mathrm{U}$ b. ABSTRACT

$\mathrm{U}$ c. THIS PAGE

$\mathrm{U}$
Transients

Water temperature

Wintertime flow
18. NUMBER OF PAGES

73 19a. NAME OF RESPONSIBLE PERSON

19b. TELEPHONE NUMBER (include area code) 